\title{
A Vinča potscape: formal chronological models for the use and development of Vinča ceramics in south-east Europe
}

\author{
Alasdair Whittle ', Alex Bayliss ${ }^{2}$, Alistair Barclay33, Bisserka Gaydarska ', Eszter Bánffy ${ }^{4}$,

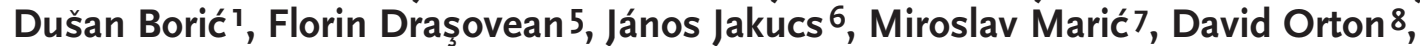 \\ Ivana Pantović 9 , Wolfram Schier ${ }^{10}$, Nenad Tasić ${ }^{11}$ and Marc Vander Linden 12 \\ 1 Department of Archaeology and Conservation, Cardiff University, Cardiff, UK \\ whittle@cardiff.ac.uk; gaydarskabı@cardiff.ac.uk; boricd@cardiff.ac.uk \\ 2 English Heritage, London, UK; and Biological and Environmental Sciences, University of Stirling, Stirling, UK \\ alex.bayliss@historicengland.org.uk \\ 3 Wessex Archaeology, Salisbury, UK; a.barclay@wessexarch.co.uk \\ 4 Römisch-Germanische Kommission, Frankfurtam Main, DE; eszter.banffy@dainst.de \\ 5 The National Museum of Banat, Timişoara, RO; fdrasovean200o@yahoo.com \\ 6 Institute of Archaeology, Hungarian Academy of Sciences, Budapest, H; jakucs86@gmail.com \\ 7 The Institute for Balkan Studies, Serbian Academy of Sciences and Arts, Belgrade, RS; dzibril@gmail.com \\ 8 BioArCh, Department of Archaeology, University of York, York, UK; david.orton@york.ac.uk \\ 9 The City Museum of Vršac, Vršac, RS; arhivana@yahoo.com \\ 10 Institute of Prehistoric Archaeology, Free University of Berlin, Berlin, DE; wolfram.schier@fu-berlin.de \\ 11 Faculty of Philosophy, Belgrade University, Belgrade, RS; ntasic@gmail.com \\ 12 Institute of Archaelogy, University College, London, UK; marc.linden@ucl.ac.uk
}

\begin{abstract}
Recent work at Vinča-Belo Brdo has combined a total of more than 200 radiocarbon dates with an array of other information to construct much more precise narratives for the structural history of the site and the cultural materials recovered from it. In this paper, we present the results of a recent attempt to construct formal models for the chronology of the wider Vinča potscape, so that we can place our now detailed understanding of changes at Belo Brdo within their contemporary contexts. We present our methodology for assessing the potential of the existing corpus of more than 600 radiocarbon dates for refining the chronology of the five phases of Vinča ceramics proposed by Milojčic across their spatial ranges, including a total of 490 of them in a series of Bayesian chronological models. Then we outline our main results for the development of Vinča pottery. Finally, we discuss some of the major implications for our understanding of the source, character and tempo of material change.
\end{abstract}

IZVLEČEK - Nedavne raziskave najdišča Vinča-Belo Brdo združujejo več kot 200 radiokarbonskih datumov z zbirko drugih podatkov z namenom ustvariti bolj natančne zgodbe o strukturni zgodovini najdišča in o izkopanem kulturnem materialu. V tem članku predstavljamo rezultate nedavnih poskusov oblikovanja formalnih modelov za kronologijo na širšem območju kulture Vinča, da lahko umestimo zdaj že podrobno razumevanje sprememb na Belem Brdu v njihove sočasne kontekste. Predstavljamo tudi našo metodologijo za ocenjevanje potenciala obstoječega korpusa več kot 600 radiokarbonskih datumov za bolj natančno kronologijo vseh petih faz vinčanske keramike, kot jih je postavil Milojčić, v njihovih prostorskih omejitvah, vključujoč še skupaj 490 datumov v seriji Bayesovega kronološkega modeliranja. Nato orišemo glavne rezultate razvoja vinčanske lončenine. Na koncu razpravljamo še o nekaterih glavnih posledicah našega razumevanja vira, značilnosti in hitrosti sprememb $v$ materialni kulturi.

KEY WORDS - Neolithic; Vinča ceramics; Bayesian chronological modelling; radiocarbon dating; network 
The significance of the Vinča culture for the development of the Neolithic in SE Europe

The Vinča culture belongs to the latter part of the sixth millennium cal BC and the first half of the fifth millennium cal BC (Chapman 1981; Markotić 1984; Borić 2009; Porčić 2011; Orton 2012). Its broad distribution extends through the river valleys - the Danube, its tributaries and their catchments of the northern and central Balkans, from southernmost Hungary and easternmost Croatia through Serbia down to Kosovo and parts of Macedonia, and from Croatia and Bosnia and Herzegovina eastwards as far as parts of Transylvania in Romania and western Bulgaria (Fig. 1). The phenomenon presents a series of significant changes in the character of Neolithic settlement and social relations (Garašanin 1979; Chapman 1981; Kaiser, Voytek 1983; Tringham, Krstic 1990a), following the initial establishment of Neolithic existence in the area of its distribution from the late seventh and early sixth millennium cal BC onwards (Whittle et al. 2002). These include changing materiality; the expansion of material networks; the spread, consolidation and diversification of settlement, involving increased sedentism in the form of large settlements and tells; the intensification of subsistence; the introduction of copper metallurgy; and the emergence of both larger communities and distinctive households within them (Chapman 1981; 2000; Kaiser, Voytek 1983; Tringham, Krstić 1990a; Tripković, Milić 2009; Orton 2010; Orton et al. 2016). Important issues of settlement expansion, population increase, changes in production, a greater variety of sites including tells themselves, more permanence of occupation, the role of households and the nature of community have all been much discussed (see also Borić 2009; 2015; Borojević 2006; Chapman 1990; Crnobrnja et al. 2009; Lazarovici 1979; Link 2006.93-6; Orton 2010; 2012; Porčić 2012; Schier 1995; Tasić 2011; Tringham et al. 1992; Tripković 2011; Whittle 1996.105).

It has been clear since the first radiocarbon dates (see Chapman 1981) that these features developed over a timescale of several centuries. Explanations of the radical transformations which both the emergence and the demise of the Vinča culture brought have varied considerably, from migrations within the culture history framework (e.g., N. Tasić et al. 1990.3233; cf. Hervella et al. 2015), to the increasing importance as time went on of individual households and competitive social relations (Tringham, Krstić 1990a; Chapman 2000). One widely shared view, within a culture-historical framework, has been of southern origins for both initiation of the Vinča culture and subsequent changes during its development (such as the claimed 'shock of Vinča C' (e.g., Garašanin 1951; 1979; G. Lazarovici 2000; Suciu 2009)). So the Vinča phenomenon is central to our understanding of social and cultural change in Neolithic southeast Europe, and also in surrounding areas. Despite the host of interpretations and chronological schemes produced, however, it remains the case that the calendar dating of Vinča culture changes - which principally boil down to changes in pottery - has not so far been rigorously or widely established, though important earlier efforts in that direction should be noted (Boric 2009; 2015; Orton 2012; Schier 1995; 1996; 2000; 2014).

\section{Periodisation schemes for Vinča ceramics: a brief historiography}

Distinctive material culture, including modelled facelike lids, figurines and copper artefacts but predomi-

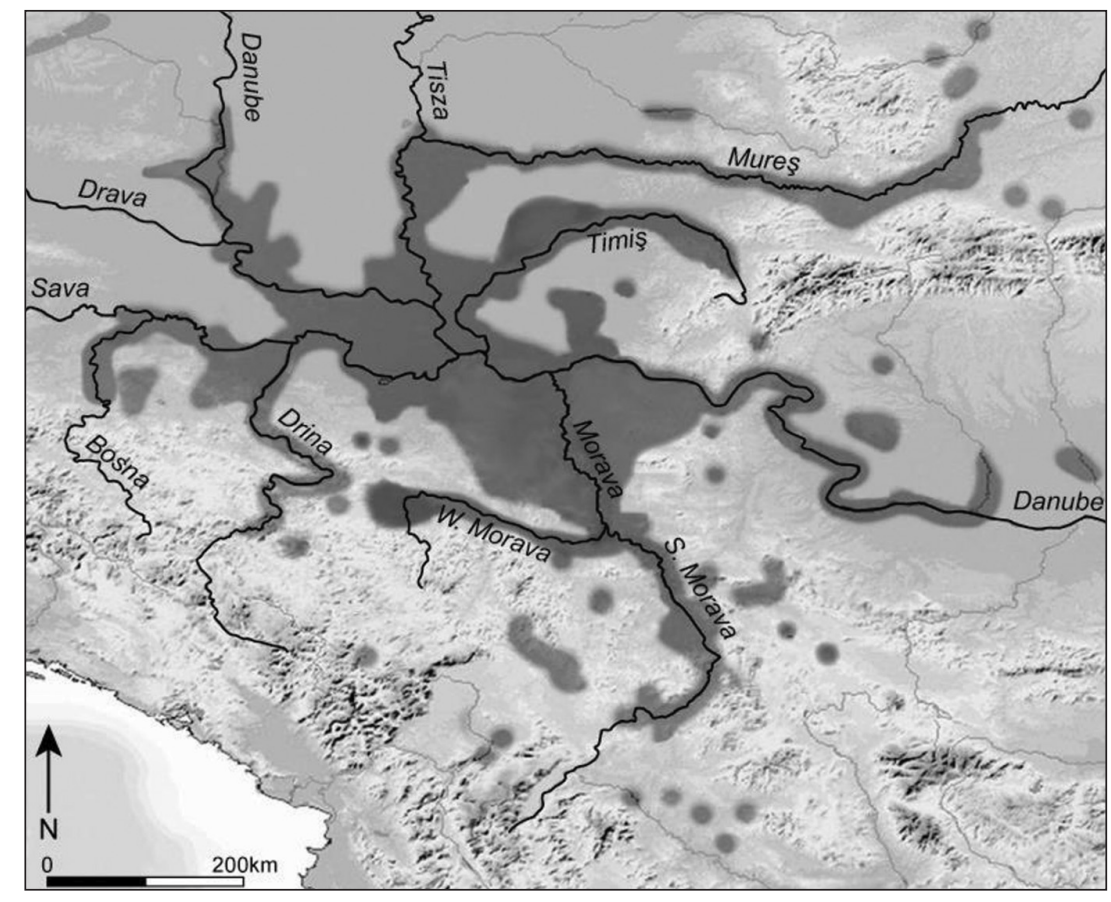

Fig. 1. Map of the maximum extent of the occurrence of Vinča ceramics across south-east Europe. 
nantly the ubiquitous, abundant and high-quality, dark-burnished pottery, has been the basis for classic periodisations of Vinča material (see Tasić et al. 2016a; Fig. 2). That these in turn have been the spur for prolonged debate about the nature and source of origins and subsequent changes underlines their continuing importance. The practice of researchers has been to infer chronology from changing typological phases of ceramics, sometimes placing this on an absolute scale by reference to the available radiocarbon dates or by analogy with dated schemes from neighbouring areas. This approach assumes that two typologically identical assemblages are synchronous, no matter their geographical location. Variation through time and variation through space are thus conflated by this approach, which has been the source of much confusion, controversy and debate.

Gordon Childe (1929.27-32; cf. Menghin 1931) had enough data to distinguish only two phases (Vinča I and II). This was based mainly on Vinča-Belo Brdo, since this provided the most abundant material. The next, more developed periodisation of Vinča-Belo Brdo was by Friedrich Holste (1939) based on the typology of pottery excavated and published by Miloje Vasić, and dividing the material into five phas- es labelled A-E, with phases A-D covering the Neolithic development of the site. Although redefined and remodelled by later authors, this basic structure continues to underpin most periodisations of Vinča material as a whole.

In 1943 and 1949 Vladimir Milojčić proposed a further refinement, using exclusively the published material from Vasić's Preistoriska Vinča 1 . He basically reproduced Holste's scheme but added subphases $\mathrm{B} 1$ and $\mathrm{B} 2$. His phase $\mathrm{B} 1$ denotes a time when meanders still appear as a decorative motif and his phase $\mathrm{B} 2$ is the time of appearance of curvilinear motifs which were more visible in the following Vinča $\mathrm{C}$ phase. Milojčić also identified a transitional C-D phase between 4.5-4 m, marking the transition to the last Neolithic phase at Belo Brdo (Milojčić 1949a.266-267; see also a useful English summary in Milojčic 1949b). He was also the first fully to incorporate other Late Neolithic sites from the central Balkans into his chronological system.

Milutin Garašanin (1951) was the first to make an inventory of the entire pottery collection from Vasićs excavations at Belo Brdo. He systematised the ceramic material and divided it into two major phases, Vinča-Tordoš and Vinča-Pločnik, also drawing

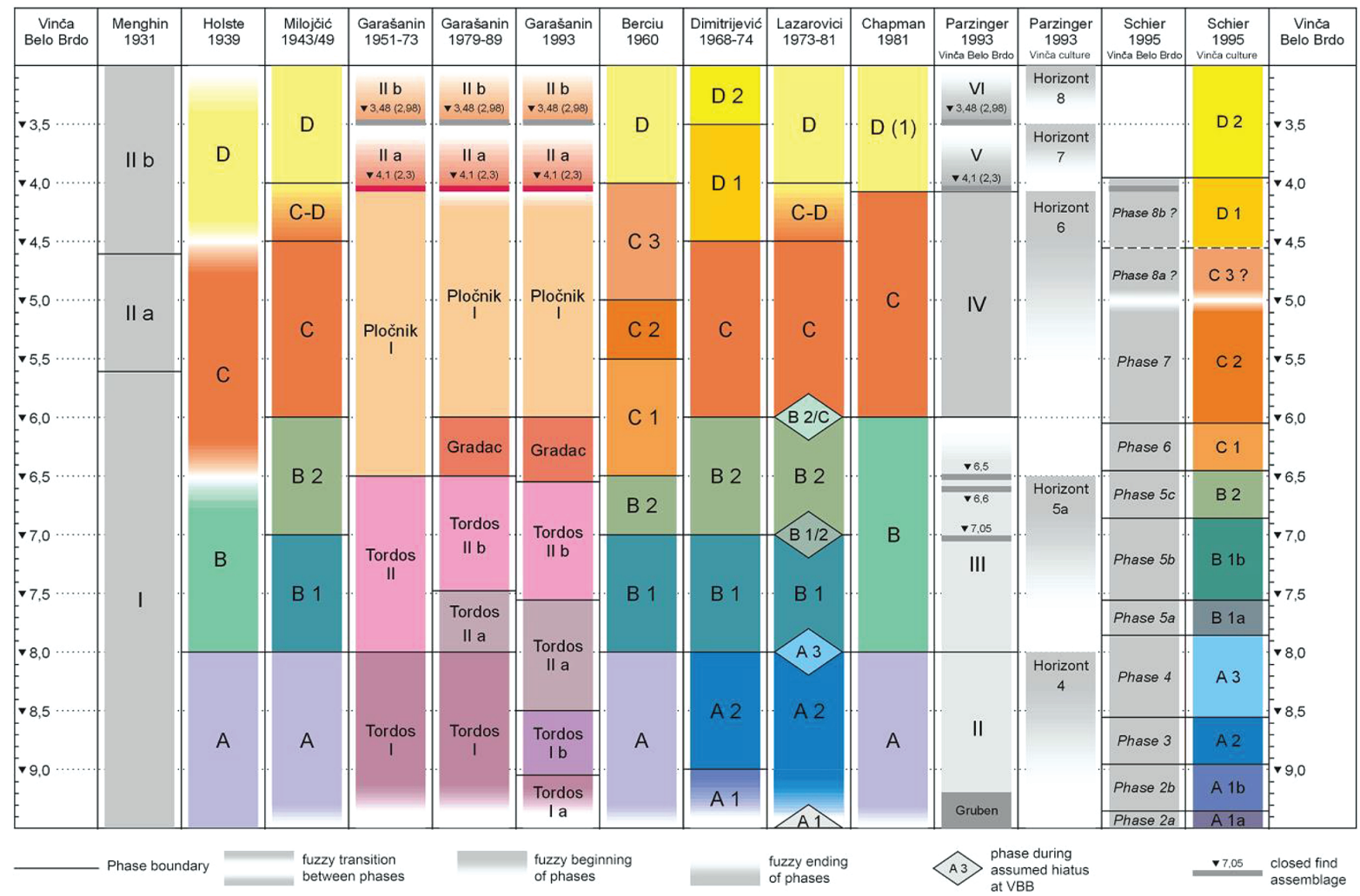

Fig. 2. Overview of alternative typological schemes for Vinča ceramics (after Schier 1996).

1 Some of his descriptions reveal that he had in-depth first-hand knowledge of the finds. 
on material from other sites in the wider Vinča distribution. He used the labels Tordoš and Pločnik to link his early and late phases of the Vinča sequence with the northernmost and southernmost sites known at the time. At first he sub-divided both his Vinča-Tordoš and Vinča-Pločnik phases, and later elaborated this division even further (Garašanin 1979; 1993). He also incorporated the views of Borislav Jovanović (1994) on the Gradac phase, which stands for a sudden and significant change in the pottery forms first attested at the south Serbian site of Gradac ${ }^{2}$.

Overlapping with and following the work of Garašanin, other periodisations essentially also based on the typology of pottery, such as those by Dumitru Berciu (1961), Stojan Dimitrijević (1968; 1974) and Gheorghe Lazarovici (1979; 1981), considered various areas of the Vinča distribution. In his quite brief treatment, Berciu essentially followed the structure already established by Milojčić, using the A-D terminology and still therefore with ultimate reliance on Vinča-Belo Brdo; his subdivision of Vinča B differs slightly from that of Milojčić and he proposed a tripartite division of $\mathrm{C}$. Vinča is correlated with other cultures of south-east Europe. His scheme principally covers Banat, Oltenia, Muntenia and Transylvania. He made some reference to available uncalibrated radiocarbon dates and suggested a relatively low absolute chronology (Berciu 1961.Fig. 1, Pl. I).

In turn, Dimitrijević concentrated on northern Serbia, Romanian Banat and Croatian Slavonia, primarily focusing on what was then called the Sopot-Lengyel culture, and using key sites like Bapska and Vinkovci, but with consideration of relationships and correlations with its neighbours. In this, reference was still made to Vinča-Belo Brdo by depth, with variation in subdivisions of $\mathrm{B}, \mathrm{C}$ and $\mathrm{D}$; for the first time, Vinča D is subdivided into D1 and D2, beginning at a depth of $4.5 \mathrm{~m}$ at Belo Brdo (Dimitrijević 1968.89, kronološka tabela). Subdivision of A followed in a later article (Dimitrijević 1974). No reference was made to radiocarbon dates, in a work completed in 1964 and a very low absolute chronology was proposed, underpinned by supposed Vinča links to Northern Greece (Dimitrijević 1968.121122).
There followed further periodisation of the Neolithic ceramic sequence in the Banat of north-west Romania by Lazarovici (1979), using the stratigraphy of key sites such as Gornea and Parţa, but yet again with reference to Vinča-Belo Brdo. The basic structure for the Vinča sequence remains familiar in outline, but A is now subdivided differently, C is simplified, a C-D phase is reinstated, and D is proposed as a single unit; transitions were also added, as $\mathrm{A} 3$ between $\mathrm{A} 2$ and $\mathrm{B} 1$, and $\mathrm{B} 1 / \mathrm{B} 2$ and $\mathrm{B} 2 / \mathrm{C}$, equivalent to what were seen as hiatuses in the Belo Brdo sequence (G. Lazarovici 1979. Tab. 7,76 ). While a range of other material is considered, it is the forms and decoration of the pottery which are described in most detail, phase by phase ( $G$. $L a$ zarovici 1979.105-139). Potential imports, from surrounding groups such as the Alföld Linearbandkeramik, Szatmár, Bükk and Petrești, are also noted (G. Lazarovici 1979.163-168). Detailed attention was given to small-scale geographical variation within the Banat, explicit distinction was made between relative and absolute chronology, and comparisons were made with much further afield, as far as Anatolia and Mesopotamia (G. Lazarovici 1979.Tabs. $17-18,178-179)$. A late absolute chronology is proposed, with the Vinča sequence placed between the late fifth and later third millennia (G. Lazarovici 1979.Tabs. 17-18, 178-179). The origins of the Vinča culture, with differences to the preceding Starčevo-Criş complex, were seen as lying in a complex set of cultural and ethnic changes and fusions, affecting the Balkans as a whole (G. Lazarovici 1979.221). Subsequently, a review of the Vinča culture across Romania, summarising chronological trends in Oltenia and Transylvania/Siebenbürgen as well as $\mathrm{Ba}$ nat, reinforced this scheme; the C-D phase was omitted on this occasion (G. Lazarovici 1981.Beilage 1). There is still no reference to radiocarbon dating, and the chronological table lacks any absolute timescale. Famously, Vinča $\mathrm{C}$ was later characterised as a 'shock', involving migration from areas to the south (G. Lazarovici 1987). Further detail and refinement for Vinča $\mathrm{C}$ in the Banat were provided by Florin Draşovean (1994; 1996; Draşovean et al. 1996).

Other reviews of the Romanian Neolithic have been published subsequently (e.g., Mantu 2000; C.-M. Lazarovici 2006; Suciu 2011). By the time of these papers, calibrated radiocarbon dates, even if rela-

\footnotetext{
2 Unfortunately, Garašanin (1979.152) misunderstood Milojčić's subdivision, maintaining that, according to the latter, the transition between Vinča B2 and C would occur around a depth of $5 \mathrm{~m}$ at Belo Brdo, instead of at $6 \mathrm{~m}$ as Milojčić had clearly stated. This led to several decades of mismatch between the two typological systems, since researchers more familiar with the Garašanin scheme consistently 'translated' the phase Vinča-Pločnik I back into the Milojčić scheme as 'Vinča B2-C' instead of correctly 'Vinča C'. We have been aware of this issue when interpreting the published ceramic phasing of dated sites in the analyses below.
} 


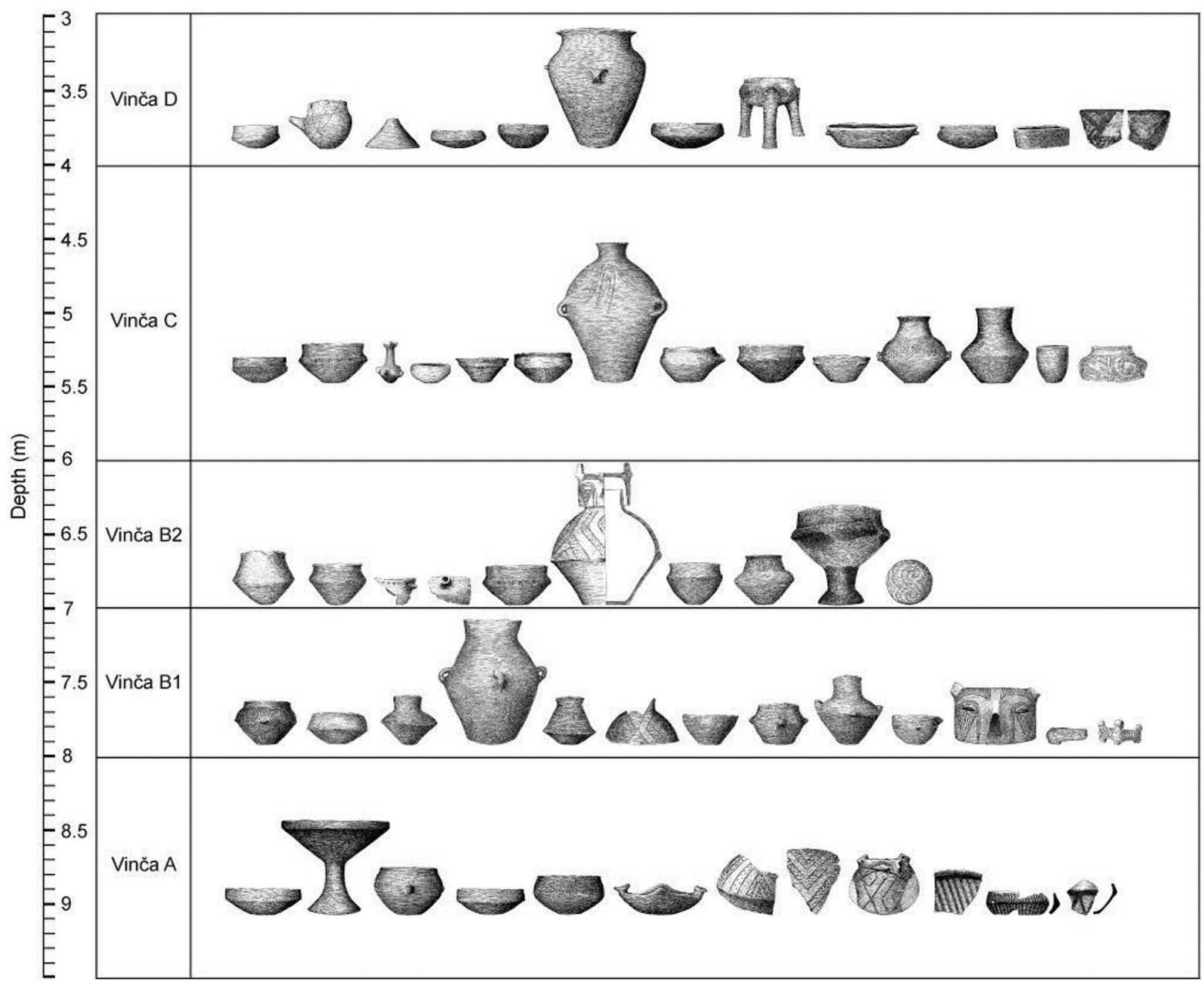

Fig. 3. Selected pot forms by depth at Vinča-Belo Brdo (after Milojčíć 1943).

tively few in number, were incorporated into chronological periodisations. It is worth noting that terms such as 'wave', 'colonisation' and 'penetration' are frequently used with reference to the Vinča culture; for example, "Vinča culture is part of the second great wave of southern origin" (Suciu 2011.75). On the basis of available radiocarbon dates, geographical variation in the effect of 'Vinča $\mathrm{C}$ type communities' is seen, with contrasts between Transylvania on the one hand and Banat and Oltenia on the other; in Transylvania, these are seen as determining the appearance of the Copper Age, whereas in Banat and Oltenia, the beginning of the Copper Age is related to new migrations due to the Tiszapolgár and Sălcuţa cultures (C.-M. Lazarovici 2006. 277). Recently, Draşovean (2014) has argued that the beginning of the Copper Age in Banat and Transylvania is tied to the emergence of Foeni-Petressti communities.

Hermann Parzinger (1993) quantified the varying occurrence of selective decorative motifs and forms by depth through the Belo Brdo tell. Following the common perception at that time, he did not assign chronological significance to the sequence of material from the relative depths in the tell, but instead gave more weight to what he considered closed assemblages, like the few house inventories recognised by Vasić (Parzinger 1993.60-63). However, this resulted in a rather small number of, arguably, unrepresentative assemblages being used in his analysis. Parzinger incorporated this in a comparative, typologically based scheme (deliberately without reference to radiocarbon dates: Parzinger 1993. 273) of successive cultural horizons, which covers the wider west Balkan region, and far beyond. At Belo Brdo itself he identified a series of Phases (I$\mathrm{VI})$, and over much wider areas a succession of horizons $(4,5 \mathrm{a}$ and $6-8$ running parallel to the Belo $\mathrm{Br}$ do sequence; Fig. 2).

The A-D division was endorsed by John Chapman (1981) for pragmatic reasons, to enable comparison within the wider Vinča culture. In his work, phases A-C denoted early Vinča and phase D late Vinča. Going beyond Vinča-Belo Brdo, and drawing on 
the then available radiocarbon dates (Chapman 1981.Fig. 14), he sketched sequences for five regions: Serbia and Macedonia, the Vojvodina, north Bosnia, Oltenia and Transylvania (Chapman 1981.22-31). Taking just the example of decorative motifs on 'early Vinča' pottery, he was able to show significant regional variation (Chapman 1981.Fig. 11).

The scheme developed by Wolfram Schier consists of eight main phases and several subphases, and covers the sequence from the beginning of the Vinča occupation on the Belo Brdo tell to $4 \mathrm{~m}$ from its top (Schier 1995; 1996; 2000). This was based on detailed analyses of changes in the form and deco-
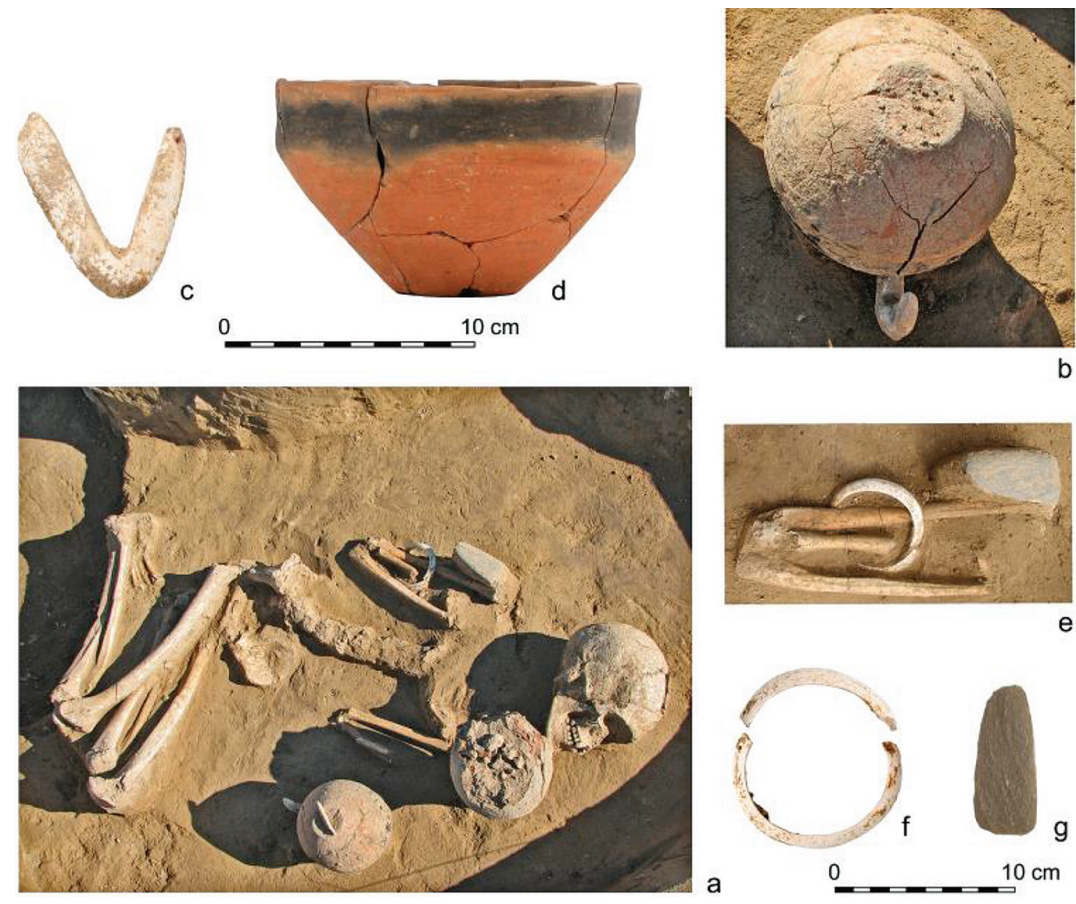

Fig. 4. Szederkény-Kukorica-dúló, Grave 2484 accompanied by a Vinča A1 (Schier 1995) bowl (after Jakucs et al. 2016). ration in a sample of about 2500 mostly unpublished vessel fragments (mainly bowls) recorded by relative depth, and its chronological credibility was tested by correspondence analysis. Schier also compared the newly defined phases with data from several other sites and concluded that the proposed division is valid at least for the 'core' area of the Vinča distribution, within a radius of some $100 \mathrm{~km}$ of Vinča-Belo Brdo itself, in the middle Morava, Šumadija and the Banat (Schier 1995.251-293; 1996.147).

Finally, since the appearance of Schier's chronology, Garašanin (2000) has refined his chronological system even further, consistent with Schier's results. Additional subdivisions have been added, including Vinča-Tordoš IIb 1-3.

Regional differences, imports, imitation and influence: issues of variability

The brief review above documents how the culture concept has persisted, perhaps largely for reasons of convenience. But it is also perfectly clear that many specialists have sought both intra- and interregional variation within the Vinča 'culture' (e.g., Garašanin 1979; G. Lazarovici 1979; Chapman 1981). The notion of a Vinča core radiating around Vinča-Belo Brdo has been proposed (Schier 1995), though this may not necessarily be accepted from the perspective of other areas (Lekovic 1990; Makkay 1990; Jovanovic 1994). There is clear recogni- tion, even within the culture-historical framework, that the affiliation or allegiance of particular regions may shift through time; cultural boundaries were not immutable or permanently fixed. Actual imports from neighbouring or surrounding regions have also been claimed, as noted above (G. Lazarovici 1979), and other potential examples were given by Cornelia-Magda Mantu (2000.80) and Florin Draşovean (1994; 1996), among others. Complex, wide-ranging interactions and fusions have been envisaged. So, at various levels, many scholars have in practice broken down a monolithic Vinča culture into a more varied and nuanced network. Yet in many accounts there is also a reversion to single explanations, especially when it comes to moments of key transition, in terms of emergence, possible rupture and endings, and the dominant threads linking these are the claimed importance of areas to the south, in the southern Balkans, northern Greece and beyond, and inferred migrations.

Given developments in aDNA studies (e.g., Brandt et al. 2013; Szécsényi-Nagy et al. 2015; cf. D. Hofmann 2015), we have to deal with population changes and infiltrations (and see again Hervella et al. 2015; and further discussion below). But what is missing from the wider field of Vinča culture studies is a more reflective sense of possible diversity and variability. The task then becomes to attempt to unpick the complex cultural history of interaction, innovation, imitation, influence, copying and import- 
ing, not excluding the possibility of population movement and replacement but equally not assuming $a$ priori that those should be the default explanations for change and variation. This paper proceeds on this basis, using pottery as its principal evidence. Ultimately, the whole range of Vinča material and practices should be the goal.

\section{Pottery as proxy dating: absolute chronology and typochronology}

Finally, by way of introduction, it is important to underline the difference between relative chronology, or sequence provided by a combination of typology (and on occasion seriation based on correspondence analysis: Schier 1995; 2000) and site stratigraphy, and absolute dating, based on formal modelling of calibrated radiocarbon dates on short-lived samples of known taphonomy, that are robustly associated with the archaeological contexts or diagnostic assemblages which they are used to date. Past generations of researchers, in the absence of large assemblages of high-quality radiocarbon dates and adequate statistical methodologies for their rigorous interpretation, have perforce attempted the synchronisation of relative sequences of pottery types based on typological considerations (perhaps with reference to the limited numbers of low-quality radiocarbon dates available to them). This form of 'pseudo' absolute chronology must be distinguished from what we propose here, which is the synchronisation of such sequences on the basis of robust statistical models of large numbers of radiocarbon dates that are directly associated with pottery which can be fitted within a common typological sequence. This approach builds upon the careful typological schemes of past research 3 , but in proper combination with scientific dating, adds absolute timescales to these sequences. Such timings, as we describe below, allow us to disentangle spatial from chronological variation in the use of these well established types.

\section{Aims of this paper: dating a potscape}

As we have seen, the Vinča culture has long been a familiar part of the culture-historical vocabulary used to frame, order, and interpret the Neolithic of southeast Europe. Many past notions derived from the use of the culture concept, however, including those of origins, identity and change, appear to have been based, in the end, largely or principally on the character and distributions of pottery styles, and the case of the Vinča complex is no exception. We are going to use the wealth of knowledge about Vinča pottery which has been built up over now a century and more of research as a key component in constructing a formally modelled chronology for the development of Vinča pottery across its wide distribution. If the landscape is what can be seen, and a taskscape what can be heard (Ingold 1993.162), a Vinča potscape could be defined as what could be held in the hands of the makers and users of the many ceramic assemblages across that distribution: borrowing Ingold on the taskscape (1993.158), "the entire ensemble ... in their mutual interlocking ... an array" of related forms. Harnessing, rather than casting aside, many of the strengths of past research on the Vinča phenomenon, we seek to discuss the many implications of our model for questions of the character and tempo of material change, and the nature of cultural variability. While we do not avoid the term, 'the Vinča culture', alternative terminology could help to recast many traditional debates (Porčić 2012.171; Borić 2015.189-195), and from here on we use other terms such as network to characterise the potscape under discussion.

In a major project, The Times of Their Lives (see Acknowledgements), we have obtained substantial numbers of new radiocarbon dates and formally modelled the results in a Bayesian statistical framework for four sites with Vinča pottery: the tell of Vinča-Belo Brdo, in northern Serbia (Tasić et al. $2015 ; 2016 a ; 2016 b)$, the tell of Uivar in western Romania (Drassovean et al. submitted; Schier et al. in preparation), and the flat settlements at Szederkény and Versend, in south-west Hungary (Jakucs et al. 2016; submitted). Encouraged by the coherent results from these sites, we were then interested to see if we could put these into the broader framework of the development of the Vinča network concentrating on the potscape of ceramic change. For this we have collected the published and other radiocarbon dates available to us in 2015. For our investigations at Vinča-Belo Brdo, we provided formal estimates for several of the available ceramic schemes (Tasić et al. 2016a.Figs. 22-24, Tabs. 8-9; and see

\footnotetext{
3 But we note the lack of rigorous, quantitative typo-chronological studies on statistically viable samples of Vinča ceramics, and the lack of representative analysis and full publication of excavated assemblages. These deficiencies in the analyses and publication of Vinča assemblages have been the major obstacle in the construction of the chronological models presented below rather than any lack of good-quality radiocarbon dates.
} 
Fig. 2), but for this paper we have used, for the sake of simplicity and wide applicability, the A-D scheme of Milojčić (1943; 1949a). Specifically, we aimed to:

- relate our models for Vinča-Belo Brdo, Uivar, Szederkény and Versend to the wider pattern of ceramic change, formally modelled within the A-D scheme for the Vinča culture;

- examine critically the temporal and geographical coherence of the A-D scheme;

- identify temporal and geographical variation in the adoption, maintenance and abandonment of ceramic styles within the A-D scheme;

- and by these means investigate the character and tempo of cultural change.

\section{Scientific dating and Bayesian chronological modelling for Vinča ceramics}

The first radiocarbon dates for Vinča ceramics were very much in the tradition of their time - one or two samples of charred material from a given site. Only a handful of sites had three to six dates. Vinča-Belo Brdo itself was fortunate to obtain two measurements on charred grain samples (GrN-1537 and GrN-1546; Vogel, Waterbolk 1963.183-184), and one measurement on a sample of unidentified charcoal (GrN1535; Todorović, Cermanović 1961.71).

At the beginning of the 1980s, Chapman (1981.1731) was able to gather details of 36 radiocarbon dates from 16 sites from which Vinča pottery had been recovered, and used these uncalibrated radiocarbon dates in comparison with local stratigraphic sequences. He reached three major conclusions: that the duration of phases $\mathrm{A}-\mathrm{C}$ was comparable to the duration of the entire $\mathrm{D}$ phase; that the final centuries of the Vinča culture were not represented at the type-site; and that the different rates of development in the various regions prevent Vinča BeloBrdo from being used as a 'type-site' for the development of the Vinča culture as a whole.

In the 1990s, Schier (1996.Tab. 1) obtained a series of 14 conventional radiocarbon dates on worked antlers and large animal bones that had been recovered by Vasić at Belo Brdo and recorded by depth. These derive from the lower and middle part of the tell (4.1-9.3m) covered by his seriation of a sample of the surviving pottery assemblage. Using these results and the first series of dates produced in Groningen, Schier (1996.Figs. 11-12) produced the first Bayesian chronological model for Vinča-Belo Brdo, combining the radiocarbon dates with the depths through the tell recorded on the samples.

At the same time Roland Gläser (1996) presented a review of 76 radiocarbon dates from 14 sites containing Vinča ceramics. He provided a Bayesian chronological model combining the site stratigraphy with the corpus of radiocarbon dates for Selevac (Gläser 1996.Fig. 5), but otherwise his analysis is based on simple calibrated radiocarbon dates and summed probability distributions of calibrated dates for selected sites, and site and ceramic phases. He suggested that the Vinča culture spanned the period from $c$. $5200 \mathrm{cal} \mathrm{BC}$ to $c .4500 \mathrm{cal} \mathrm{BC}$.

Dušan Borić (2009) mustered a total of 155 radiocarbon dates from 27 sites associated with Vinča pottery, including 40 new AMS measurements on short-life, single-entity samples from seven sites. Bayesian models were presented for six sites: Belo Brdo, Rudna Glava, Belovode, Pločnik, Gomolava and Divostin II. This analysis suggested that the culture dated from 5400-5300 cal BC to 4650-4600 cal BC. Contrary to Chapman, Borić argued (2009. 234) for an approximately similar duration of each phase (A to D) of $200 \pm 50$ years. More recently, a set of 26 new AMS dates on animal bone from Gomolava, Opovo and Petnica have been published and Bayesian models constructed (Orton 2012). These new dates generally fit the chronological framework suggested by Borić.

\section{The chronological framework and approach}

It is now time not only to compare these new site chronologies with each other, but also to set them within the wider framework of other dated sites that formed part of the Vinča network. We consider a corpus of 564 radiocarbon dates that have been published as relating to Vinča pottery (Tab. 1) ${ }^{4}$. Full details of these measurements are provided in Table 2 where we have gathered information from diverse sources or when measurements are published for the first time. Where full details of measurements have already been published (e.g., Borić 2009) references to sources used for each site are provided in Table 1.

Chronological modelling has been undertaken using the program OxCal v4.2 (Bronk Ramsey 2009; Bronk

\footnotetext{
4 Additionally, there are 34 radiocarbon dates from the latest levels of Vinča-Belo Brdo in Sector II (Tasić et al. 2015), 101 from the recently excavated deep sounding (Tasic et al. 2016b), and two from the 2011 profile that are not considered here.
} 
Ramsey, Lee 2013) and the calibration dataset of Reimer et alii (2013). The algorithms used in the models are defined exactly either by the brackets and OxCal keywords on the left-hand side of the figures or by the CQ2 code provided as supplementary information (http://c14.arch.ox.ac. uk/). In the figures, the outputs from the models, the posterior density estimates, are shown in black, and the unconstrained calibrated radiocarbon dates are shown in outline; dates on samples of charred plant remains that may have an old-wood offset are shown in grey; the parameter names of distributions that have been excluded from the modelling are followed by '?'. Some distributions do not relate to single radiocarbon dates. These other distributions correspond to aspects of the model. For example, the distribution 'start Szederkény' (Fig. 5) is the posterior density estimate for the time when the settlement at Szederkény was established. In the text and tables, the Highest Posterior Density intervals of the posterior density estimates are given in italics. Calibrated date ranges given in normal type have been calculated using IntCal13 and the probability method (Stuiver, Reimer 1993), and do not derive from the chronological models described. All ranges have been rounded outwards to five years.

For each measurement, we examine the character of the dated material and its association with Vinča ceramics. Given the absence of an agreed typological scheme across the region, assemblages have been allocated to Milojčićs (1943; 1949a) scheme: A, B1, B2 (incorporating what was later called the Gradac phase), C (incorporating Milojčić's (1949a; 1949b) phase $\mathrm{C}-\mathrm{D}$ ), and $\mathrm{D}$ (incorporating all proposed subdivisions) (Fig. 3). Where site stratigraphy is available, this is used in a Bayesian model to constrain the calibration of the radiocarbon dates. In some cases the available published information is not sufficient to demonstrate a robust association between the dated samples and a ceramic phase(s) (these results are reported in footnotes).

Ideally, we wish to include in our models only radiocarbon dates on short-life samples that are directly associated with typologically diagnostic assemblages of the relevant pottery. Dates on articulated animal bones from closed ceramic assemblages in pits, for example, are ideal (for a demonstration of the potential of this approach see Denaire et al. in press). Unfortunately, the samples submitted for dating by past researchers, the published typological and stratigraphic information, and the reporting of the radiocarbon measurements and their associated details (Bayliss 2015) are frequently less than ideal. In these circumstances, we have been forced to make pragmatic judgements about the information available to us.

We have only included radiocarbon dates in our study that are published as having a clear association with Vinča ceramics that have been assigned to various typological schemes ( $c f$. Fig. 2), which we have converted to the Milojčić (1943) scheme. This means that sites often have more radiocarbon dates than have been used in the modelling, but these are either associated with activity of other periods or do not have explicit associations with diagnostic Vinča material. In many cases it has been impossible for us to judge the validity of the published ceramic association, as sites are not yet published in detail. Sometimes associations cannot be made at the feature or structure level, but rather an entire site is categorised as only containing material of a certain phase. It should be noted that the association between cultural material and the radiocarbon sam-

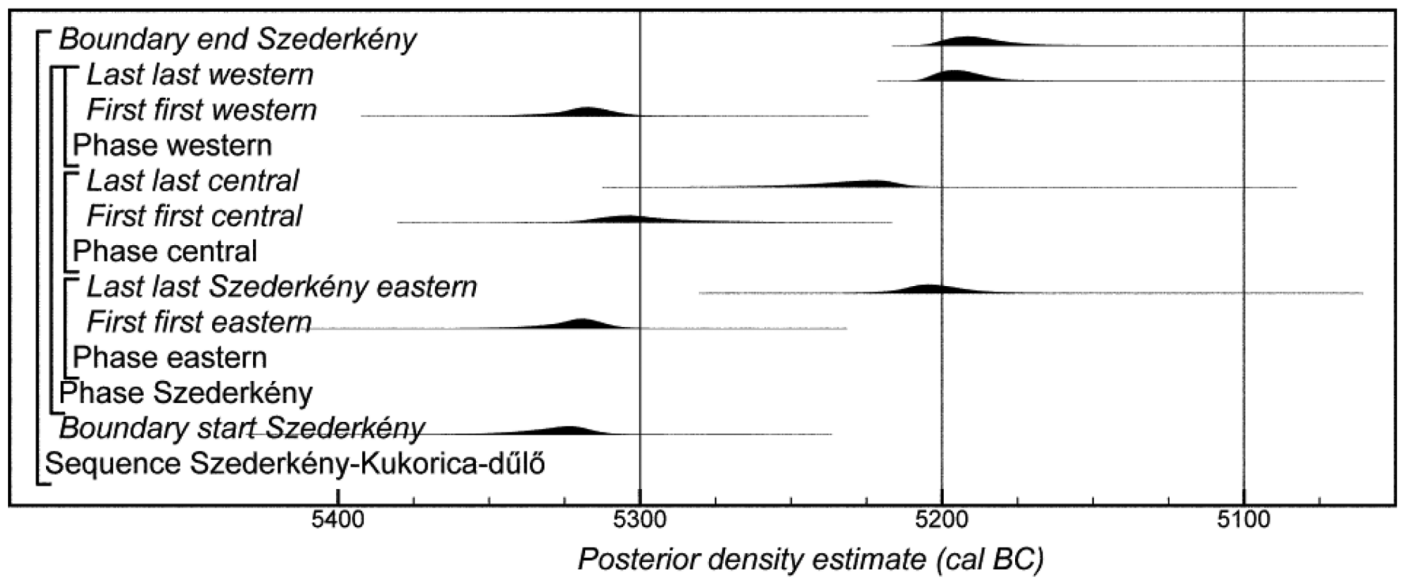

Fig. 5. Probability distributions of key parameters from Szederkény-Kukurica-dúló, derived from the model defined by Jakucs et al. (2016.Fig. 10). 
ple is critical to avoid circular arguments (by which a site is assigned to particular ceramic phase on the basis of the calibrated radiocarbon dates rather than the typological characteristics of the pottery present).

This legacy dataset is inevitably of variable quality. Although over $70 \%$ of measurements have been made by AMS, short-life, single-entity samples that can be confidently associated with the use of the feature from which the sample derived constitute less than a quarter of dates (and $80 \%$ of those derive from just two sites, Szederkény and Versend). Over $20 \%$ of samples were of unidentified charcoal (or of charcoal from long-lived species such as oak and elm) and so may incorporate an old-wood offset. Other samples consist of disarticulated animal bones or single carbonised cereal grains, where it is not known whether the dated material derived from particular concentrations. Such materials might well be residual (older than their contexts) or intrusive (younger than their contexts).

We have attempted to distil reliable chronology from this body of data, by incorporating each result into the model in a way that is appropriate for the dated material.

- Samples of human bone from graves, articulated animal bone groups, and short-lived charred plant remains (including short-life charcoal) from fired features such as hearths or large concentrations, such as coherent dumps in pits, have been incorporated into the models as short-life material likely to be contemporary with the archaeological activity of interest $(n=134)$.

- Disarticulated animal bones and short-lived charred plant material from houses or pits have also been included fully in the models, although we consider the archaeological association in this case to be less reliable $(n=244)$; in a number of cases the dates on these samples are clearly much earlier than related dates (usually having a poor individual index of agreement in the model) and so they have been modelled as residual termini post quos $(\mathrm{n}=43)$, and in a few cases they are clearly intrusive $(\mathrm{n}=8)$.

- Samples of unidentified charcoal (or charcoal from long-lived species) have been incorporated into the models as termini post quos $(\mathrm{n}=115)$, except for a few which are statistically consistent with results on short-life materials from the same context $(\mathrm{n}=5)$.
- Five results from Uivar have been excluded from the model for that site for technical reasons (Schier et al.forthcoming).

In total, therefore, our models include 490 radiocarbon measurements (with a further 66 not included in the analysis either because there is a significant possibility that the measurements are inaccurate, or because we think the dated material was intrusive, or because the association with the Vinča ceramics is unclear). A total of 134 measurements on short-lived samples firmly associated with the dated context are included fully in the models (27\%); a further 193 measurements on short-life material that can be associated with the dated context less reliably have also been included fully in the modelling (40\%), with another 43 such samples modelled as termini post quos as the dated material was probably residual (9\%); and 120 measurements on charcoal samples of uncertain maturity are included in the models as termini post quos $(24 \%)$. Our analysis suggests that overall there is approximately a $25 \%$ chance that a disarticulated animal bone, or a short-life charred plant from a deposit with which it is not functionally related, is residual or intrusive. This demonstrates the need to date articulating bone groups or single fragments of short-lived charred plant material from primary deposits (Bayliss et al. 2016).

This analysis provides quantitative date estimates for Milojčić's (1943) ceramic phase boundaries at different sites that are independent of any synchronisation between alternative typological schemes. In some cases the character of the dated material means that samples can only provide termini post quos for particular ceramic phases, or can only be allocated to a range of ceramic phases. We start by considering the chronologies and ceramic associations of particular sites, and construct chronological models for sites which have more than three radiocarbon dates on short-lived material with robust ceramic associations. We then construct a series of models for the chronology of each of Milojčićs's ceramic phases, utilising posterior distributions from the site-based models as inputs for these models where appropriate and calibrated radiocarbon dates where not. This ensures that sites which have many radiocarbon dates (e.g., Uivar or Belo Brdo which between them have almost half of the radiocarbon measurements considered in this review) do not disproportionately affect the analysis. 


\section{The Vinča potscape}

We discuss the dated sites from west to east, following the Danube downstream and examining sites in the catchments of its tributaries as these join the river (Fig. 1).

\section{The Danube upstream of the Tisza}

A linear strip $1.7 \mathrm{~km}$ long, comprising $12.5 \mathrm{ha}$, was investigated at Szederkény-Kukorica-dúló between 2005 and 2008. The site lies approx. 20km west of the current course of the Danube in south-eastern Transdanubia, Hungary. A total of 66 longhouses, orientated NE-SW and broadly conforming to the longhouse architecture which is generally perceived as a hallmark of the central European Linearbandkeramik (LBK), and 50 crouched inhumations were recovered. Most of the graves are unfurnished, although some were accompanied by Vinča ceramics (Fig. 4). Vinča pottery, from Schier's (1996) A1A3 phases, was recovered from settlement features (Jakucs, Voicsek 2015). This material can be related to Milojčić phase A used in this study.

Forty-one radiocarbon measurements are available from this site (Jakucs et al. 2016.Tab. 1), of which 19 are from features containing diagnostic Vinča A ceramics. These dominated the assemblages from the eastern and central areas of the site (the western part contained mainly Ražište-type pottery). János Jakucs et alii (2016.Fig. 11) present a model for the chronology of Szederkény, which is summarised in Figure 5. This estimates that Vinča A ceramics appeared here in 5360-5305 cal BC (95\% probability; start Szederkény; Fig. 5), probably in 53405315 cal BC (68\% probability), and ceased to be used in 5230-5175 cal BC (95\% probability; last Szederkény eastern; Fig. 5), probably in 5215-5190 cal BC (68\% probability).

The site of Versend-Gilencsa lies in southern Hungary, approx. $2 \mathrm{~km}$ east of Szederkény-Kukorica-dúló (Jakucs et al. submitted). A linear strip totalling 2.24ha was excavated along the planned line of the motorway, divided by the course of the Versend stream. Features of the Neolithic settlement could be detected on the floodplains of the eastern and western side of the watercourse.

On the eastern side, unambiguous traces of 21 longhouses orientated NE-SW could be identified. These were arranged in rows, and each was flanked by longitudinal pits containing mixed assemblages of early LBK and Vinča A ceramics. The density of archaeological features was higher on the western side, where the extensive traces of the Neolithic settlement were heavily destroyed by later activity. The houses were consequently much less identifiable.

Sixty-eight radiocarbon measurements are available from this site (Jakucs et al. submitted.Tab. 1). Jakucs et alii (submitted.Figs. 5-6) present a model for the chronology of Versend, which is summarised in Figure 6 . This estimates that the settlement began in 5305-5280 cal BC (2\% probability; start Versend settlement; Fig. 6) or 5255-5210 cal BC (93\% probability), probably in 5235-5215 cal BC (68\% probability), and ceased to be used in 5220-5180 cal BC (93\% probability; end Versend settlement; Fig. 6) or 5150-5115 cal BC (2\% probability), probably in 5210-5195 cal BC (68\% probability).

Several occupation horizons that include assemblages of Vinča pottery have been recovered from the tell settlement at Bapska, eastern Croatia, in 13 campaigns of excavation between 1911 and the present (Burić, Težak-Gregl 2009; Burić 2011). Two radiocarbon measurements are available from the 1964 trench; one from the foundation of House 2$\mathrm{A}$ is associated with an assemblage described by Dimitrijević (1968.92) as Vinča D1 and equated by him with Milojčić's phase C-D. This dating, being on charcoal from a potentially long-lived species, thus provides a terminus post quem of 4850-4485 cal BC (Bln-348; 95\% probability) or 4780-4580 cal BC (68\% probability) for the end of Milojčić phase $\mathrm{C}$ at Bapska 5 . A further series of radiocarbon measurements have recently been obtained on short-lived material associated with Houses 1 and 2 from renewed excavations (Burić, Težak-Gregl 2009; Burić 2015). These appear to be associated with Vinča $C$ or Vinča D ceramics, and can be modelled as spanning 4645-4495 cal BC (95\% probability; start Bapska C/D; Fig. 7), probably 4580-4515 cal BC (68\% probability), and 4550-4420 cal BC (95\% probability; end Bapska C/D; Fig. 7), probably 4535-4475 cal BC (68\% probability).

\section{Tisza and Mures valleys}

The site of Maroslele-Pana is located in south-eastern Hungary, on the right (northern) bank of the Maros (Mureş) river, northwest of the village of Maroslele,

5 A second sample from the 1964 excavations (Bln-346, 5955 \pm 80 BP, 5055-4665 cal BC (94\% probability) or 4640-4615 cal BC (1\% probability)) is associated with Sopot II pottery and is thus not included in this study. 


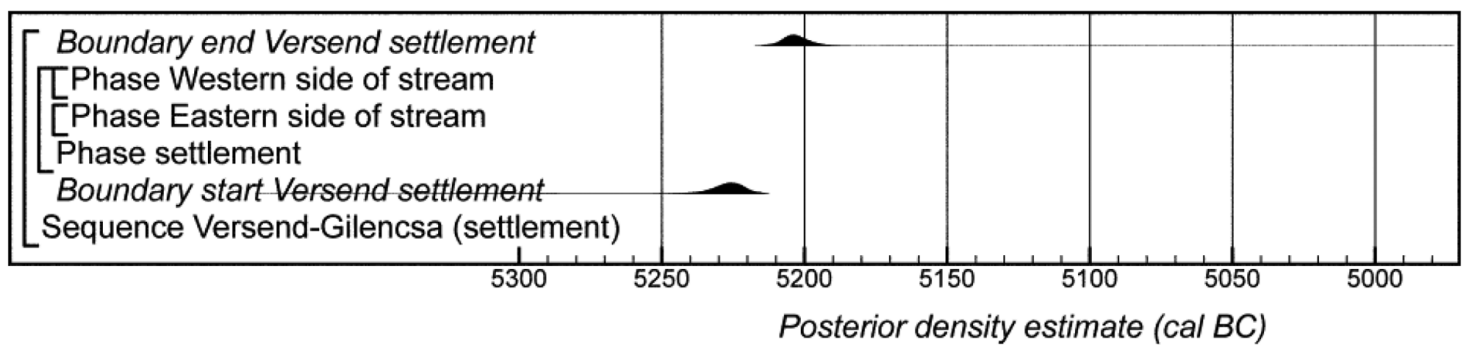

Fig. 6. Probability distributions of key parameters from the settlement at Versend-Gilencsa, derived from the model defined by Jakucs et alii (submitted.Figs. 5-6).

close to the confluence of the Tisza and Maros rivers. The site was first excavated in 1963; four Neolithic features (pits 1-4) and five crouched burials were documented (Trogmayer 1964). The pottery from this early campaign represented the late phases of the early Neolithic Körös culture. In 2008 there were further excavations in advance of road construction. The excavation took place on a low ridge and covered 2.7ha. A total of 71 of the 231 excavated features can be dated to the Neolithic period (Paluch 2011). Five radiocarbon measurements were obtained on animal bone from separate pits (Tab. 2). The dated pits contained diagnostic early Vinča A1-A2 (Schier 1996) and early Alföld LBK style pottery, but also some fragments and altar pieces which showed clear resemblances to the pottery style of the late Körös culture. The Vinča A1-A2 elements are most frequent in pit 85 , while the other dated pits contain more equal proportions of early Vinča and Alföld LBK style material. The mixed (Vinča and Alföld LBK with early Neolithic traits) assemblage of Maroslele-
Pana in the Tisza-Maros confluence area (Paluch 2011) can be seen as a similar phenomenon to that observed at Versend-Gilencsa in southern Transdanubia and at Satchinez in northern Banat. The model for the dated activity from Maroslele-Pana has good overall agreement (Amodel: 106; Fig. 8) and suggests that the site was occupied between 5380-5220 cal BC (95\% probability; Start Maroslele-Pana A; Fig. $8)$, probably in 5325-5250 cal BC (68\% probability), and 5300-5095 cal BC (95\% probability; End Maroslele-Pana A; Fig. 8), probably 5275-5195 cal BC (68\% probability).

At Ószentiván (site 8) four measurements were taken on bulk charcoal from a pit containing Vinča A pottery that was investigated during rescue excavations in 1960 (Kohl, Quitta 1970). This material was identified as oak and elm charcoal, both species that can live to several hundred years, and so the combined result provides a terminus post quem for the pottery of 5305-5050 cal BC (95\% probability; Ószentiván 8)

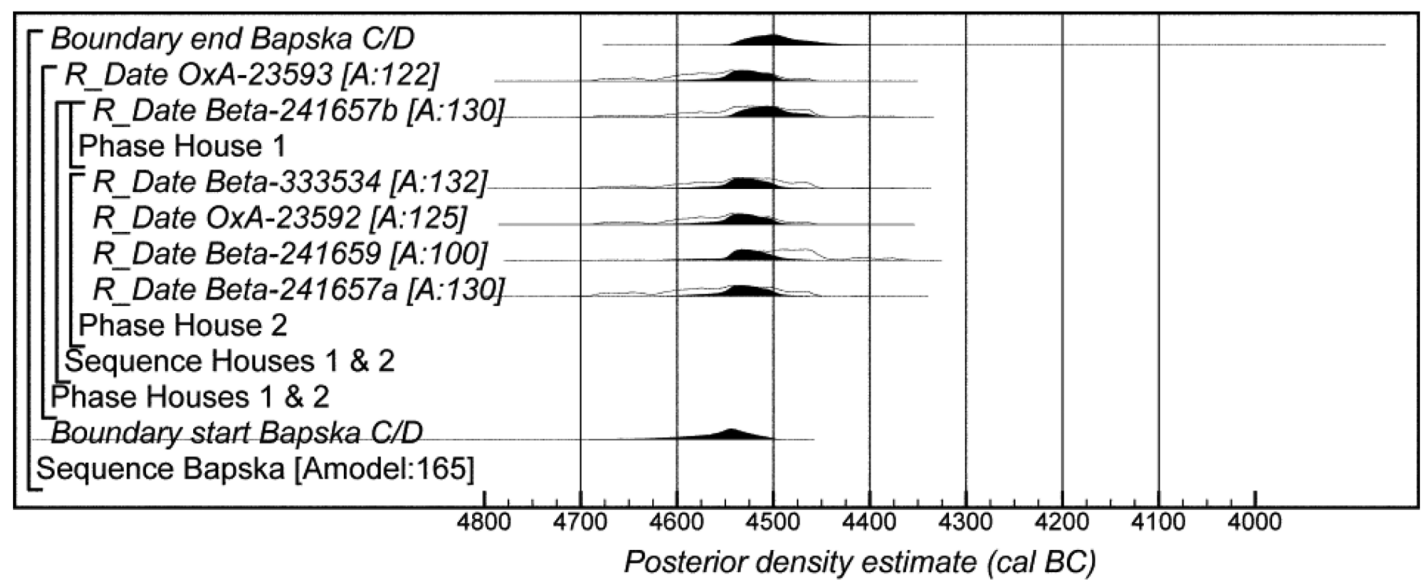

Fig. 7. Probability distributions of radiocarbon dates from Bapska. Each distribution represents the relative probability that an event occurs at a particular time. For each of the dates two distributions have been plotted: one in outline, which is the result of simple radiocarbon calibration, and a solid one, based on the chronological model used. Distributions other than those relating to particular samples correspond to aspects of the model. For example, the distribution 'start Bapska D' is the estimated date when Vinča D ceramics first appeared on the site. Measurements followed by a question mark and shown in outline have been excluded from the model for reasons explained in the text, and are simple calibrated dates (Stuiver, Reimer 1993). The large square brackets down the left-hand side along with the OxCal keywords define the overall model exactly. 
or 5295-5245 cal BC (19\% probability) or 5235$5200 \mathrm{cal} \mathrm{BC}(13 \%$ probability) or $5170-5075 \mathrm{cal} \mathrm{BC}$ (36\% probability). A single sample of unidentified charcoal was dated from pit 1 , recovered in later excavations at the same site (published as Tiszasiget), which was also associated with Vinča A ceramics (Trogmayer 1980.298). This provides a terminus post quem for the assemblage of 5465-5445 cal BC (1\% probability; Bln-1631) or 5380-5190 cal BC (78\% probability) or $5185-5055$ cal BC (16\% probability), probably $5340-5205$ cal BC (68\% probability).

The site of At is located to the north-west of Vršac in south-eastern Banat, Serbia. The settlement was located on a sloping terrace on the north-west edge of Veliki rit, a marshy area drained in the mid-nineteeth century. Several seasons of rescue excavations revealed the existence of a multi-period prehistoric site, ranging from the Lower Palaeolithic to the Late Neolithic (Joanovič, Prikić 1978). Renewed excavations in 2014-2015 revealed a structure of the Starčevo period, and cut features associated with Vinča $\mathrm{C}$ and Vinča D ceramics (Chu et al. 2016). Four radiocarbon dates are available from the Vinča layers, two from pit 1 and two from the infilling of the Starčevo structure. These place this activity between 6040-5960 cal BC (1\% probability; Start At C/D; Fig. 9), or 5700-4660 cal BC (94\% probability), probably in 5050-4720 cal BC (68\% probability), and 4595-3510 cal BC (94\% probability; End At $C / D$; Fig. 9), or 3180-3090 cal BC (1\% probability), probably in 4535-4190 cal BC (68\% probability). These estimates are extremely imprecise, with very long tails to the distributions, because there are currently few dates from this site.

Also in the vicinity of Vršac is the 100ha flat settlement of Potporanj, which has produced early Vinča pottery and the largest quantity of obsidian found within the Vinča network. Provenance studies of this material show that it came from the Hungarian and Slovakian Carpathian Mountains (Tripkovic, Milić 2009). Three radiocarbon dates are available from recent excavations of the site by Vršac Museum. MAMS-22667, a sample of unidentified charcoal that may have an old-wood offset, provides a terminus post quem of 5210-5000 cal BC (95\% probability) or $5210-5160$ cal BC (25\% probability) or 5120 5105 cal BC (4\% probability) or $5080-5005$ cal BC (39\% probability) for an assemblage of Vinča A ceramics in the earliest occupation level. MAMS-22666, also a sample of unidentified charcoal, provides a terminus post quem of 5215-5015 cal BC (95\% probability) or $5210-5090 \mathrm{cal}$ BC (51\% probability) or $5085-5050$ cal BC (17\% probability) for the use of Vinča B2/C ceramics in the latest habition level of the site. The third date, MAMS-22668, is on animal bone from a level associated with Vinča B2 pottery and dates this deposit to 5295-5240 cal BC (9\% probability) or 5235-5190 cal BC (19\% probability) or $5180-5060$ cal BC (67\% probability), probably $5220-5200$ cal BC (13\% probability) or 5170-5075 cal BC (55\% probability).

A sample of antler was dated from pit 4 at the Neolithic settlement of Satchinez, north-eastern Banat, Romania, which contained sherds of Vinča A2 pottery along with LBK sherds (Drassovean 1993; Horváth, Draşovean 2010.15). This provides a date of 5325-5200 cal BC (Deb-2579; 87\% probability) or $5165-5115$ cal BC (5\% probability) or 5110-5075 cal BC (3\% probability), probably $5300-5220$ cal BC (68\% probability) for this assemblage. Also in northeastern Banat, Romania, two samples of antler have been dated from pit 4 at Hodoni, a multi-period site which has produced 20 pits containing Vinča C pottery (Drasovean 1994; 1996). These dates place this assemblage at 4845-4650 cal BC (93\% probability; Hodoni: pit 4; Fig. 32) or 4640-4615 cal BC (2\%

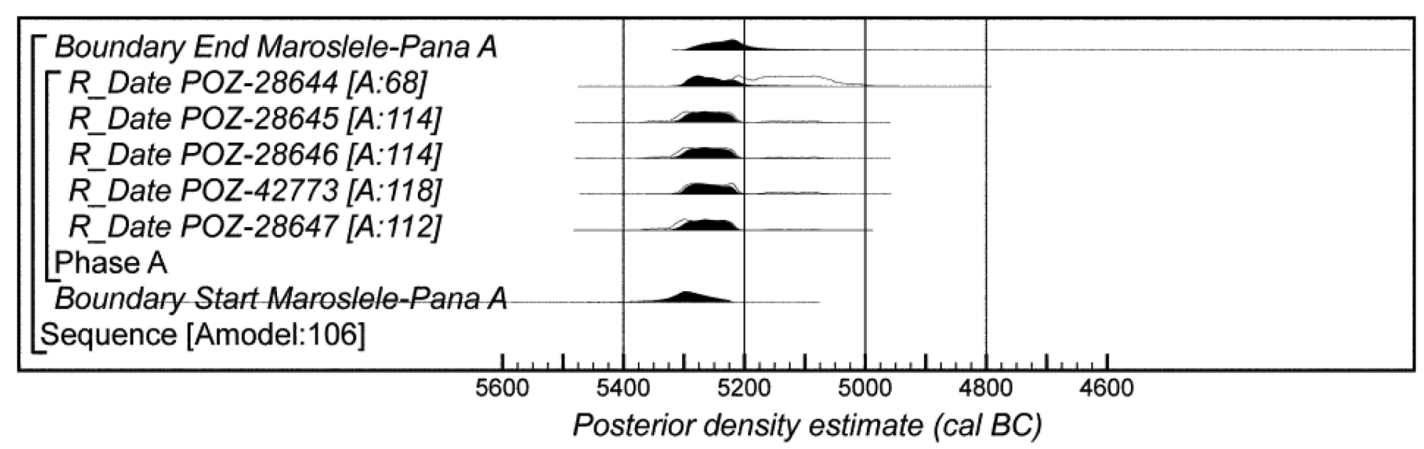

Fig. 8. Probability distributions of radiocarbon dates from Maroslele-Pana. The format is identical to that of Figure 7. The large square brackets down the left-hand side along with the OxCal keywords define the overall model exactly. 


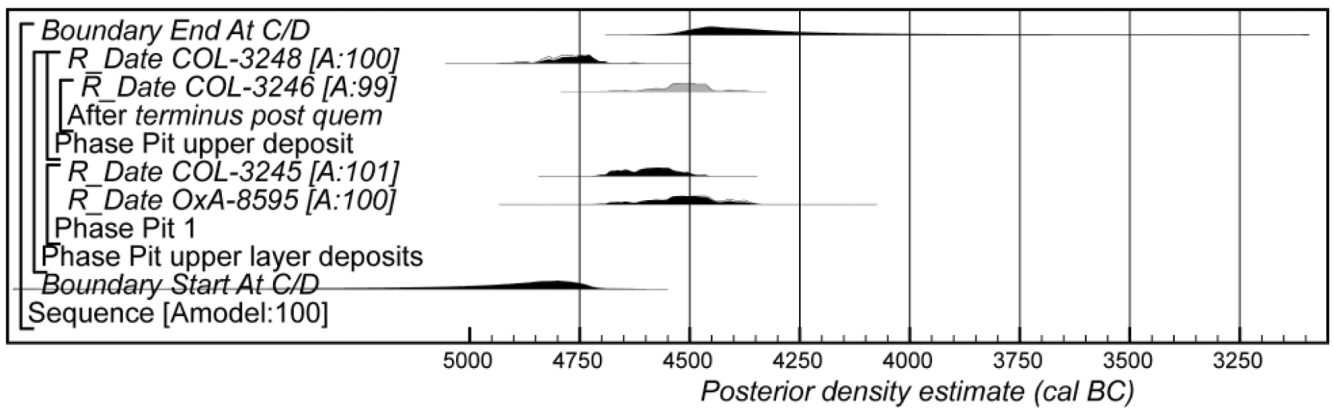

Fig. 9. Probability distributions of radiocarbon dates from At. The format is identical to that of Figure 7 (grey tone indicates the sample has a possible old-wood offset). The large square brackets down the lefthand side along with the OxCal keywords define the overall model exactly.

probability), probably at $4795-4705$ cal BC (68\% probability).

The tell site of Uivar in the Romanian Banat was excavated between 1999 and 2009 by a RomanianGerman team (Schier, Drassovean 2004; Schier 2008; Draşovean, Schier 2009; Schier 2016). It consists of a central tell settlement $4 \mathrm{~m}$ high and covering some $3 \mathrm{ha}$, which was surrounded by a series of substantial ditches, some accompanied by palisades. These enclose an area of some 12ha. A flat settlement occupied at least some of this, and may have succeeded occupation on the tell itself. A complete sequence through the tell was excavated in Trench 1. A recent programme of chronological modelling utilising a total of 182 radiocarbon measurements from the site formally estimates the chronology of this complex (Schier et al.forthcoming; Drassovean et al. submitted).

Only preliminary analyses of the pottery assemblages from the site have been undertaken so far. The lowest deposits in Trench 1 contained pottery predominantly in the Szakálhát tradition. The first Vinčatype sherds appear to be local imitations of Milojčić B1 (Schier 1995.phase B). They occur from the construction horizon of $\mathrm{H} 3 \mathrm{~d}$ in $5045-4990 \mathrm{cal}$ BC $(95 \%$ probability; build $\mathrm{H} 3 \mathrm{~d}+\mathrm{c}$; Fig. 10), probably in 50355000 cal BC (68\% probability). The first sherds of Schier (1995) phase C1 (equivalent to late Milojčić B2, see Fig. 2) pottery appear in the construction horizon of $\mathrm{H} 3 \mathrm{c}$, which unfortunately could not be dated directly since the structure did not provide suitable samples. The date of its appearance can be estimated, however, since this must be between the construction of buildings $\mathrm{H} 3 \mathrm{~d}$ and $\mathrm{H} 3 \mathrm{~b}$. This model is shown in Figure 10 and suggests that late Milojčić B2 (Schier 1995.phase C1) pottery first appeared in 5030-4930 cal BC (95\% probability; start Milojčic B2 at Uivar), probably in 5010-4950 cal BC (68\% probability). It becomes predominant on the site from the construction horizon $\mathrm{H} 3 \mathrm{~b}$ in 4985-4910 cal BC (95\% probability; build H3b; Fig. 10), probably in 4960-4925 cal BC (68\% probability). Milojčić C (Schier 1995.phase C2) pottery appears from the construction of the H3a horizon in 4920-4850 cal BC (95\% probability; build H3a; Fig. 10), probably in 4905-4895 cal BC (8\% probability) or 4890-4855 cal BC (60\% probability). No sherds of Milojčić C-D (Schier 1995.phase D1) pottery have been recovered from Uivar, and so Milojčić $\mathrm{C}$ ceramics appear to have been current until the end of the Neolithic occupation of the tell in 4740-4600 cal BC (95\% probability; end Uivar tell; Fig. 10), probably in 4725-4645 cal BC (68\% probability).

Three samples of bone have been dated from the site at Tărtăria, Transylvania, Romania (Merlini 2011. 224; Merlini, Lazarovici 2008.156). One is from a partial female skeleton found disarticulated and mixed with animal bone in the pit which is thought to have contained the Tărtăria tablets, one from cleaning of the 1942-1943 section, and one from the base of pit B2. Merlini places the pottery from the pit containing the skeleton in the Vinča phase A2 or A3, although Lazarovici (2010.Fig 8) places the same assemblage in Vinča A3/B1; he also places the assemblage from pit $\mathrm{B} 2$ in this phase. We have interpreted these classifications to refer to an assemblage of Vinča B1 pottery, which contained surviving elements of Vinča A3.

The taphonomy of the dated material and its association with the recovered ceramics are problematic. The animal bone from the base of pit $\mathrm{B} 2$ probably provides a date for the associated Vinča B1 pottery (although, of course, it is always possible that a disarticulated bone is residual). This result calibrates to $5315-5000 \mathrm{cal} \mathrm{BC}$ (R-1655; 95\% probability), probably to $5295-5250$ cal BC (13\% probability) or $5230-5195 \mathrm{cal} \mathrm{BC}(12 \%$ probability) or 5180 5065 cal BC (43\% probability). The dated animal 


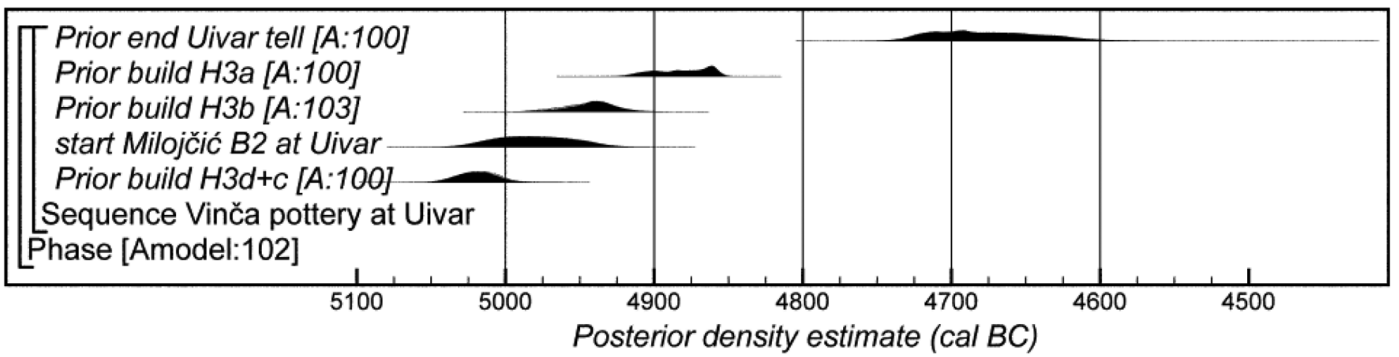

Fig. 10. Probability distributions of key parameters relating to the use of Vinča ceramics at Uivar. The format is identical to that of Figure 7. The large square brackets down the left-hand side along with the OxCal keywords define the overall model exactly (key parameters have been imported from the model defined by Schier et alii (forthcoming.Figs. 6.9, 6.12-6.22).

bone from the section is effectively unstratified and cannot be securely associated with the pottery 6 . Interpretation of the date on the female partial skeleton is more complicated, since there appears to be evidence that the body was exposed for a period of time before burial in the pit associated with the tablets. For this reason, in this study we have included this date as a terminus post quem for the use of the Vinča B1 ceramics from the pit. This is 54705200 cal BC (88\% probability; R-1631) or 5165$5115 \mathrm{cal} \mathrm{BC}$ ( $4 \%$ probability) or $5110-5075 \mathrm{cal} \mathrm{BC}$ (3\% probability), probably $5360-5215$ cal BC (68\% probability) 7 .

The settlement at Miercurea Sibiului-Petris, in the catchment of the upper Mures valley, consisted of surface houses and pits (Luca et al. 2006). These appear to be associated with Vinča B ceramics. Four radiocarbon dates are available on short-lived materials from two pits and a house (Tab. 2) ${ }^{8}$. Pit 18 is stratigraphically earlier than pit 3 and house 11 , although GrA-33127 from pit 18 appears to be on a residual cereal grain and so is incorporated in the model as a terminus post quem. This model has good overall agreement (Amodel: 79; Fig. 11), and suggests that Vinča B occupation here occurred between 5650-5025 cal BC (95\% probability; Start Miercurea Sibiului-Petris B), probably 5290-5095 cal BC (68\% probability), and 5280-4590 cal BC (95\% probability; End Miercurea Sibiului-Petris B), probably $5170-4970$ cal BC (68\% probability) 9 .

6 This sample was an unidentified animal bone recovered from the cleaning of the section of the 1942/3 excavation and produced

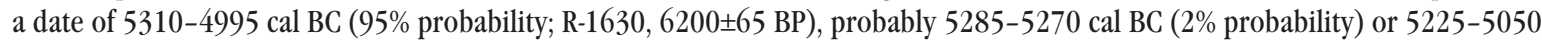
cal BC (66\% probability).

7 The radiocarbon dates raise the possibility that Milady of Tărăria was curated for some time before her bones were buried in this pit. It is $83 \%$ probable that R-1631 is earlier than R-1655, probably by -115-375 years ( $95 \%$ probability; distribution not shown), probably -10-240 years (68\% probability). The negative parts of these ranges reflect the possibility that her bones were freshly deposited.

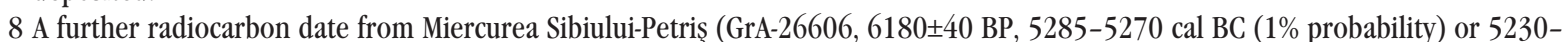
5000 cal BC (94\% probability)) appears to be on an animal bone that was intrusive in Starčevo pit 9 (Luca et al. 2006).

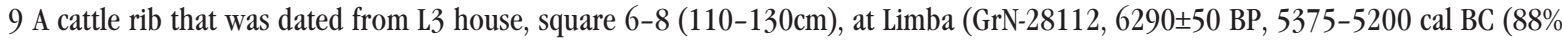
probability) or $5170-5075 \mathrm{cal} \mathrm{BC}$ ( $7 \%$ probability), is from a house that was expected to be contemporary with the Criş IV ceramics within it (Biagi et al. 2005.49). The painted vessel has been attributed to Vinča A2 (Lazarovici 2009.184-185; 2010. 115-116; 2014.16-18, Figs. 3, 5c), Vinča A2-A3 (Mazâre 2005.258, 288), or Starčevo-Criş IV (Draşovean 2014.footnote 10). It appears to be a Lumea Noua import. The result is later than expected and has been reassigned to Vinča A3, although the publication does not provide evidence of an association with Vinča A3 ceramics. This result is therefore not included in the modelling presented here (Suciu 2009.37). Similarly, the association between the cattle tibia dated by GrN-28994 (5760 440 BP, 4710 4515 cal BC (95\% probability) and the, probably earlier Vinča ceramics, recovered from Cauce Cave is unclear and this result is also not included in this analysis (Suciu 2009.67-9, Fig. 82, Annex 1). Three radiocarbon dates from Orăștie-Dealul Permilor (Deb-5762, 5825 \pm 60 BP, 4830-4535 cal BC (95\% probability); Deb-5765, 6070土70 BP, 5210-4825 cal BC (94\% probability) or

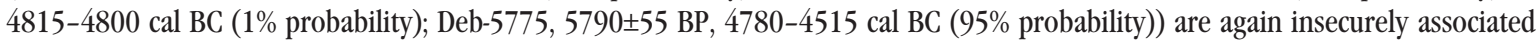
with Vinča pottery and are not modelled here (Luca 2003). Eight radiocarbon measurements are available from Cârcea Viaduct, although these samples cannot be associated with Vinča pottery at all (contra Mantu 2000.99; Biagi, Spataro 2005.37; Bln-1980, $6100 \pm 60 \mathrm{BP}, 5215-4880$ cal BC (93\% probability) or 4870-4845 cal BC (2\% probability); Bln-2008, $6550 \pm 40 \mathrm{BP}, 5615-5585$ cal BC ( $7 \%$ probability) or $5570-5465$ cal BC ( $88 \%$ probability); Bln- $2287,6300 \pm 55 \mathrm{BP}, 5465-5440$ cal BC (2\% probability) or $5425-5405$ cal BC (1\% probability) or 5385-5200 cal BC (86\% probability) or 5170-5075 cal BC (7\% probability); Bln-2289, $5910 \pm 55$ BP, $4945-4680$ cal BC (95\% probability); Bln-2291, 5990 55 BP, 5005-4725 cal BC (95\% probability); Bln-2292, $6350 \pm 60$ BP, 5470-5220 cal BC (95\% probability); Bln-2294, 5865 \pm 95 BP, 4965-4495 cal BC (95\% probability); and Bln-2354, $5860 \pm 60 \mathrm{BP}, 4850-4545$ cal BC (95\% probability)). 


\section{Sava valley and tributaries}

The site of Lupljanica, with Vinča pottery, is located in the valley of the Bosna River, one of the main tributaries of the Sava in central Bosnia. A single sample of unidentified charcoal was dated from the lowest level of a house structure, $1.3 \mathrm{~m}$ below the surface (Breunig 1987.107; Crane, Griffin 1972. 190-191), and provides a terminus post quem of 4910-3985 cal BC (M-2455; 95\% probability), probably $4705-4255$ cal BC (68\% probability) for the end of Vinča D.

The Neolithic tell at Gornja Tuzla is located on the slopes of Mt. Majevica in the upper part of the Jala river catchment. It was discovered in 1949 and is estimated to be between 12 and 15 ha in size. Excavations were undertaken over four seasons between 1955 and 1958 (Čović 1961.79-139). Five radiocarbon measurements associated with Vinča period activity have been published, but only two have robust ceramic associations 10 . These are measurements on unidentified charcoal found in association with Vinča $\mathrm{C}$ pottery that provide termini post quos for this pottery of 4535-4330 cal BC (GrN-1974; 95\% probability) or $4460-4355$ cal BC (68\% probability) and of $4780-4355 \mathrm{cal} \mathrm{BC}$ (Bln-349; $95 \%$ probability) or $4685-4455$ cal BC (68\% probability).

The multi-period tell at Gomolava is in Vojvodina, Serbia, on the east bank of the river Sava. It was first detected in 1898, and small-scale excavations were undertaken in 1904-1908. The first systematic excavations took place between 1953 and 1985 , with approximately half a hectare investigated ( $\mathrm{Gi}$ rić 1988.13; Brukner 1980; 1988). This yielded a number of prehistoric occupation horizons ranging from the late Neolithic to late Iron Age. However, the site is best known for its late Vinča necropolis (Borić 1996; Jovanović 2015), one of only very few discovered thus far in the Balkans.

Fifteen samples are on unidentified charcoal and may have contained material with an old-wood offset; the other 17 samples are on short-lived materials (two bulk samples of carbonised cereal grain, four human burials, and 11 animal bones; Waterbolk 1988.Beilage 1; Orton 2012.Tab. 2; Borić 2009.Tab. $5)$.

A model for the dated Vinča activity at Gomolava has good overall agreement between the radiocarbon dates and the stratigraphic information (Amodel: 80; Fig. 12), only if three dates that fall in the early Bronze Age are excluded as outliers (all considered to be intrusive from later phases of activity: GrN-7373, GrN-7375 and 0xA-21132).

The model presented in Fig. 12 suggests that Vinča C started at Gomolava in 5005-4845 cal BC (95\% probability; Start Gomolava C; Fig. 12), probably in 4955-4875 cal BC (68\% probability); the boundary between phases $C$ and D occurred in 4810-4720 cal BC (95\% probability; Gomolava C/D; Fig. 12), probably in 4790-4735 cal BC (68\% probability); and

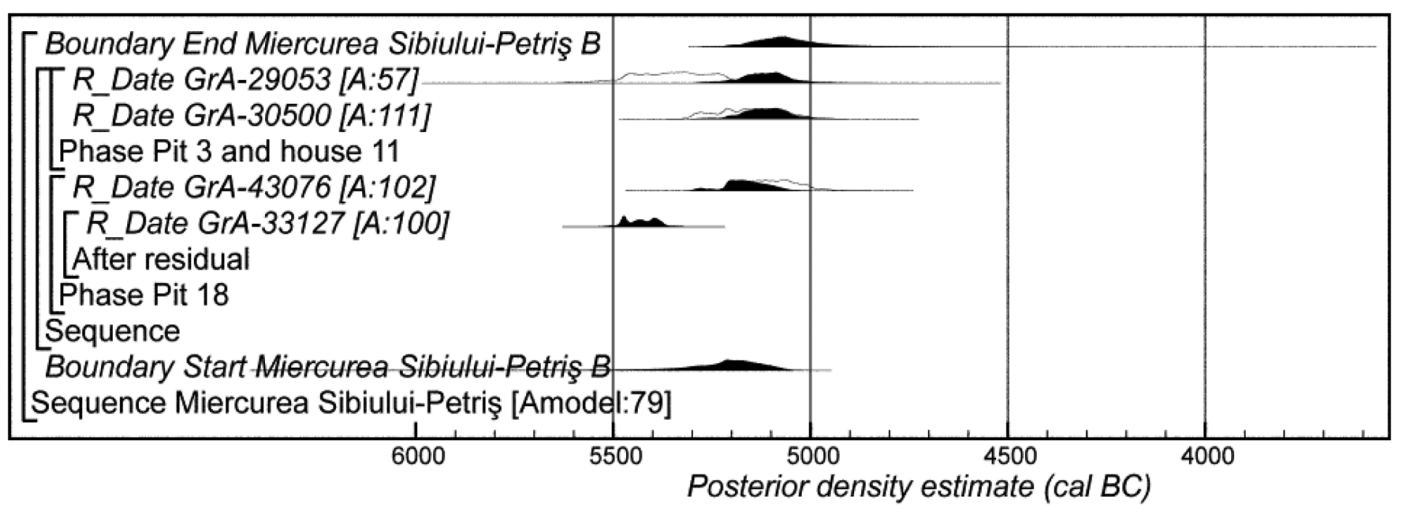

Fig. 11. Probability distributions of radiocarbon dates from Miercurea Sibiului-Petriş. The format is identical to that of Figure 7. The large square brackets down the left-hand side along with the OxCal keywords define the overall model exactly.

10 Three further measurements have been obtained from more recent excavations at Gornja Tuzla (Vander Linden et al. 2014). OxA-23297 (6165 \pm 34 BP, 5220-5015 cal BC (95\% probability)) on a large mammal bone from layer 15 does not appear to be securely associated with a diagnostic ceramic assemblage. Two further statistically consistent measurements (0xA-23298, 5827 \pm 33

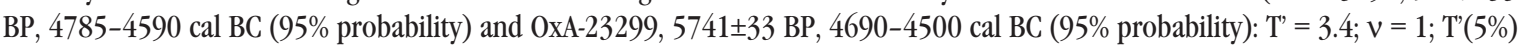
$=3.8$ ) were obtained on different species of animal bone (Bos taurus and Cervus elaphus) from layer 8 . These samples also have no known direct ceramic associations. 


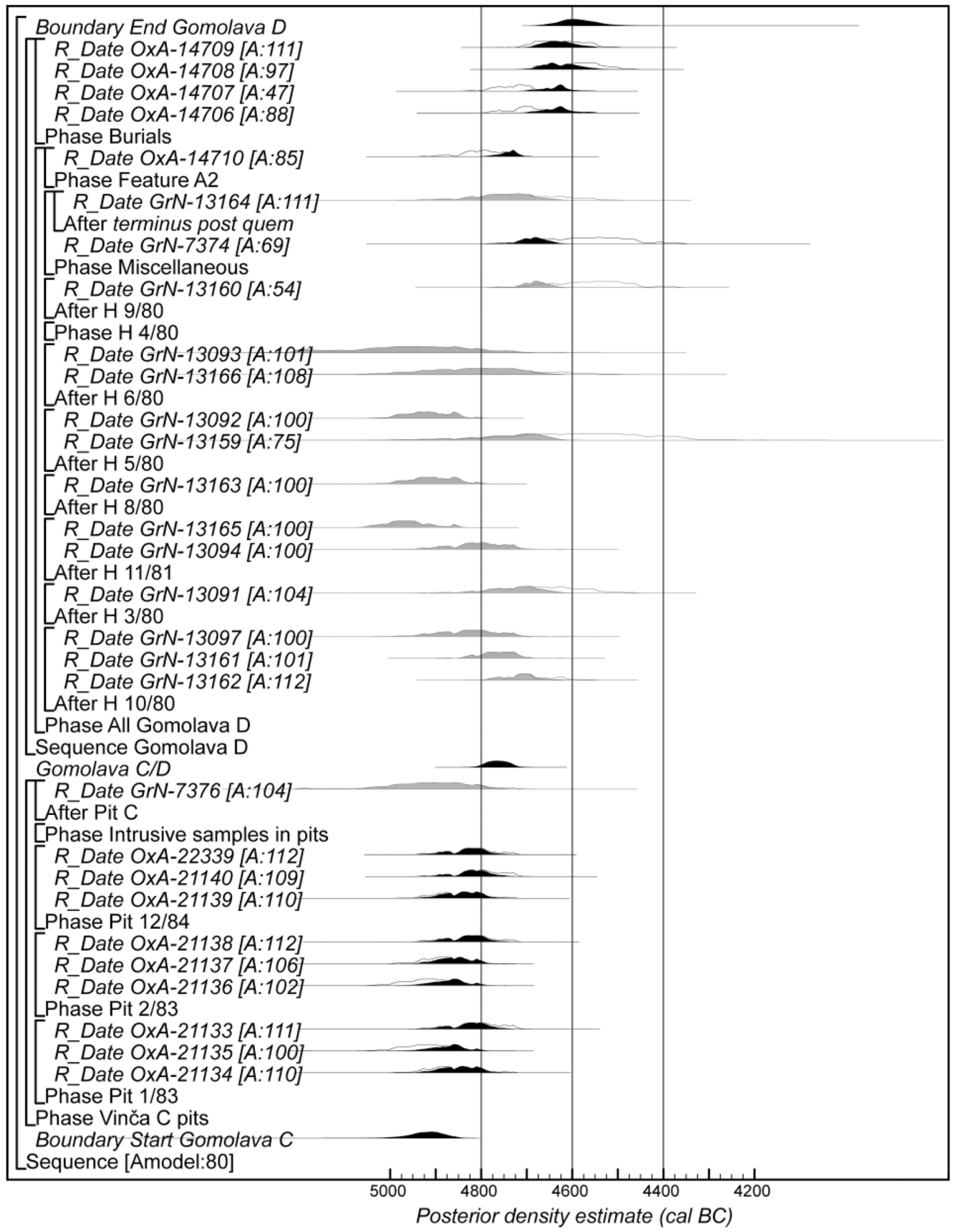

Fig. 12. Probability distributions of radiocarbon dates from Gomolava. Distributions for GrN-7373, GrN7375, and 0xA-21132, which are considered to derive from post-Neolithic activity, are not shown. Grey tone indicates that the sample has a possible old-wood offset. The format is identical to that of Figure 7. The large square brackets down the left-hand side along with the OxCal keywords define the overall model exactly.

phase D ended here in 4670-4500 cal BC $(95 \%$ probability; End Gomolava D; Fig. 12), probably in 4635-4550 cal BC (68\% probability).

The Neolithic settlement at Petnica is located in the Kolubara valley area in western Serbia, on a slope running up to a north-facing cliff. A cave in this cliff was also occupied in this period. The site has been excavated on several occasions, yielding three late Neolithic occupation phases and several Vinča-period wattle and daub structures (Starović 1993).

Seven radiocarbon dates have been obtained on animal bone samples from occupation features at Petnica (Boric 2009.Tab. 6; Orton 2012.Tab. 2). The model for the dated activity at Petnica has good over- 
all agreement (Amodel: 94; Fig. 13), if we interpret Pit 3 as being cut from above the level of House 3 and if we interpret the animal bone from House 2 as residual. We follow the ceramic phasing for Petnica published by David Orton (2012).

This model suggests that phase B2 at Petnica started in 5050-4850 cal BC (95\% probability; Start Petnica B2; Fig. 13), probably in 4995-4900 cal BC ( $68 \%$ probability); the boundary between phases B2 and $\mathrm{C}$ occurred in 4965-4850 cal BC (95\% probability; Petnica B2/C; Fig. 13), probably in 49404880 cal BC (68\% probability); the boundary between phases $C$ and D occurred in 4950-4845 cal BC (95\% probability; Petnica $C / D$; Fig. 13), probably in 4925-4860 cal BC (68\% probability) and the dated sequence ended in 4935-4735 cal BC (95\% probability; End Petnica D; Fig. 13), probably in 49004800 cal BC (68\% probability).

The site of Masinske Njive is located in western Serbia on a tributary of the Kolubara River. The site was originally recorded in the 1960s and was excavated in full between 2006 and 2009 in advance of coal mining. A single phase Vinča settlement was excavated, which produced Vinča B1/B2 ceramics (M. Spasić, pers. comm.).

Three radiocarbon measurements have been obtained on samples of animal bone from settlement features. A model for the dated activity at this site has good overall agreement (Amodel: 100; Fig. 14), and indicates that this activity began in 5705-5085 cal BC (95\% probability; Start Masinske B; Fig. 14), probably in 5355-5215 cal BC (68\% probability), and ended in 5300-4700 cal BC (95\% probability; End Masinske B; Fig. 14), probably in 5275-5070 cal BC (68\% probability).

Barely 500m west of Masinske Njive, on an elevated terrace above the same tributary of the Kolubara River, lay the early Vinča A site of Jaričište 1. Although the site was recorded in the 1960s, it was only excavated between 2006 and 2010 and has since been destroyed by the Kolubara coal mine (Marić 2013). The early Vinča settlement featured several dozen pits, some containing ovens, although no wattle and daub structures were detected.

A single flax seed was dated from pit 1.137, which contained an assemblage of Vinča A pottery, indicating that these ceramics date to $5320-5205$ cal BC (88\% probability; NOSAMS-78623) or $5165-5135 \mathrm{cal}$ BC (3\% probability) or $5130-5115 \mathrm{cal} \mathrm{BC}$ ( $1 \%$ probability) or $5110-5075 \mathrm{cal} \mathrm{BC}$ (3\% probability), probably in $5300-5240 \mathrm{cal} \mathrm{BC} \mathrm{(53 \%} \mathrm{probability)} \mathrm{or} \mathrm{5235-}$ 5215 cal BC (15\% probability).

\section{The Belgrade area}

The tell site of Belo Brdo at Vinča just east of Belgrade forms the type-site for the development of Vinča pottery. The $8 \mathrm{~m}$ of Neolithic deposits have been excavated almost constantly since 1908 , when Vasić began large scale excavations. The massive assemblage of pottery from these excavations has been the subject of a series of seminal typological

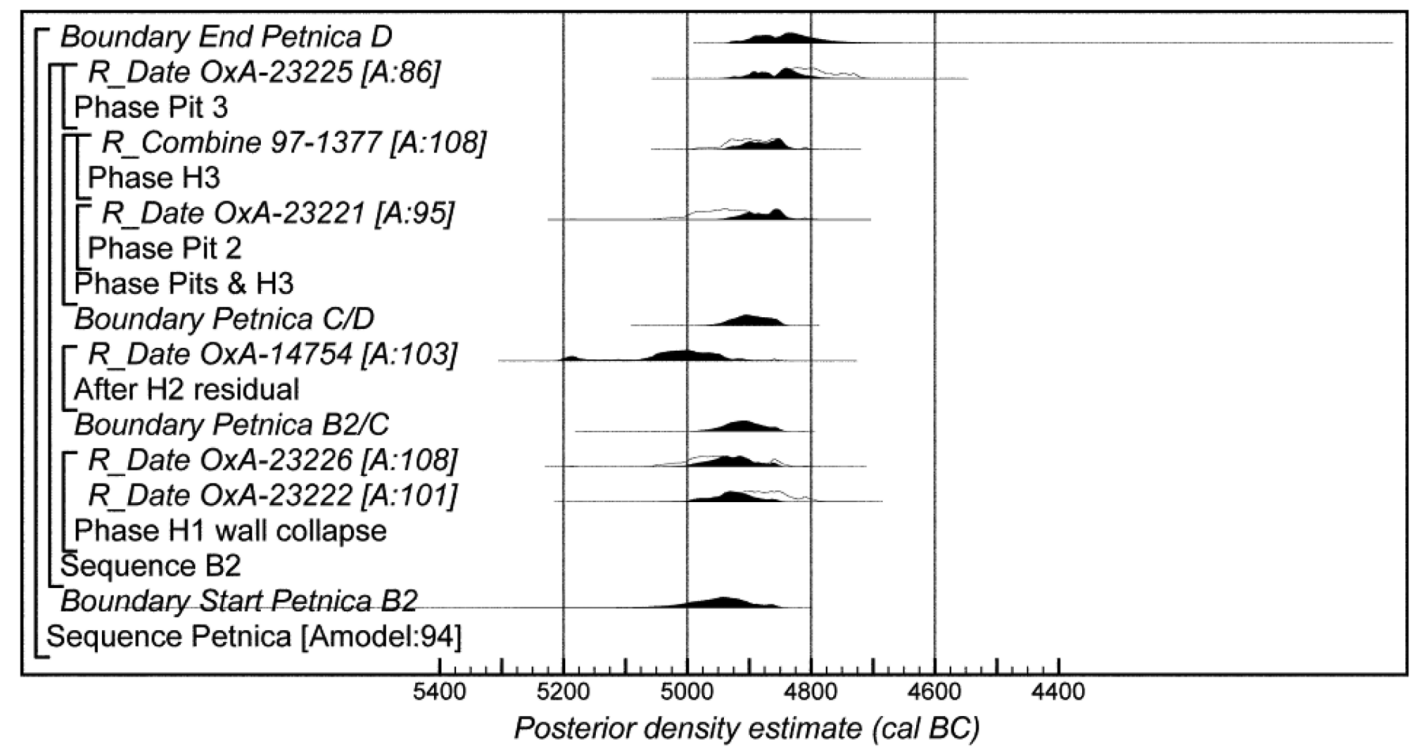

Fig. 13. Probability distributions of radiocarbon dates from Petnica. The format is identical to that of Figure 7. The large square brackets down the left-hand side along with the OxCal keywords define the overall model exactly. 


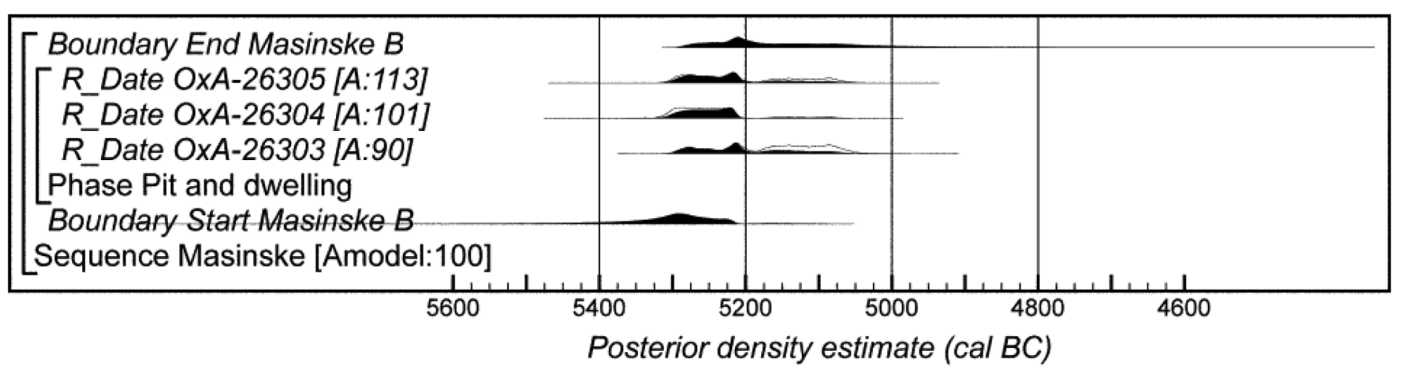

Fig. 14. Probability distributions of radiocarbon dates from Masinske Nive. The format is identical to that of Figure 7. The large square brackets down the left-hand side along with the OxCal keywords define the overall model exactly.

studies (Fig. 2), the sequence through the tell providing relative chronology for the schemes suggested. As part of the The Times of Their Lives project, major new programmes of radiocarbon dating have been undertaken on the Vasić sequence (Tasić et al. $2016 a$ ), the excavations of the upper levels in Sector II (Tasic et al. 2015) and the sequence from a new deep sounding excavated between 2004-2014 ( $\mathrm{Ta}$ sić et al. 2016b).

Most relevant to the chronology of Vinča ceramics is the model presented by Tasić et alii (2016a.Fig. 17) for the sequence of deposits excavated by Miloje Vasić, as these excavations covered a larger area than those of all subsequent excavations combined and consequently produced by far the largest assemblage of Vinča pottery. This is a Poisson process agedepth model with the rigidity of the process defined as the $10 \mathrm{~cm}$ spits used by Vasic to excavate the tell and record the recovered finds (Bronk Ramsey 2008; Bronk Ramsey, Lee 2013). The typological scheme for Vinča pottery published by Milojčić (1943) used in this study was based on the published ceramics from this archive recorded by these spits. The agedepth model thus explicitly estimates their dates. Milojčić phase A occurs between $9.3 \mathrm{~m}$ and $8.0 \mathrm{~m}$, phase $\mathrm{B} 1$ between $8.0 \mathrm{~m}$ and $7.0 \mathrm{~m}$, phase $\mathrm{B} 2$ between $7.0 \mathrm{~m}$ and $6.0 \mathrm{~m}$, phase $\mathrm{C}$ between $6.0 \mathrm{~m}$ and $4.0 \mathrm{~m}$, and phase $\mathrm{D}$ from $4.0 \mathrm{~m}$ to the top of Vinča cultural layers at $1.3 \mathrm{~m}$.

On this basis, at Belo Brdo Milojčić phase A begins in 5305-5255 cal BC (95\% probability; Belo Brdo start $A$; Fig. 15), probably in 5300-5270 cal BC (68\% probability). The transition between Milojčić $\mathrm{A}$ and B1 occurs in 5210-5135 cal BC (95\% probability; Belo Brdo A/B1; Fig. 15), probably in 52005165 cal BC (68\% probability). The shift between Milojčić B1 and B2 occurs in 5115-5040 cal BC (95\% probability; Belo Brdo B1/B2; Fig. 15), probably in 5090-5055 cal BC (68\% probability). The transition between Milojčić B2 and C happens in
4935-4850 cal BC (95\% probability; Belo Brdo B2/ C; Fig. 15), probably in $4920-4875 \mathrm{cal} \mathrm{BC}(68 \%$ probability). The transition between Milojčić phases $\mathrm{C}$ and D occurs in 4765-4680 cal BC (95\% probability; Belo Brdo C/D; Fig. 15), probably in 47604735 cal BC (12\% probability) or 4725-4690 cal BC (56\% probability). Milojčić (1943) placed the end of his phase $\mathrm{D}$ at $2.5 \mathrm{~m}$ at Belo Brdo, but the accumulation of Vinča ceramics within the deposits of Belo Brdo continues up to a depth of $1.3 \mathrm{~m}$, until 4570-4460 cal BC (95\% probability; Belo Brdo end $D$; Fig. 15), probably in 4550-4495 cal BC (68\% probability).

The presence of Vinča $\mathrm{D}$ ceramics above relative depth of $2.5 \mathrm{~m}$ at Belo Brdo was confirmed by excavations in Sector II undertaken between 1998 and 2009, where such ceramics occur until 4550-4485 cal BC (95\% probability; fire 2; Tasić et al. 2015. Fig. 8), probably in 4545-4505 cal BC (68\% probability). This date estimate for the end of Vinča D at Belo Brdo is completely independent of that provided by the age-depth model of the Vasic sequence, but the medians of these probability distributions vary by just three years. The chronological modelling of the new sounding provides much greater detail on the structural narrative of the tell but, given the small area excavated and the small quantity of material recovered, this area does not add materially to our understanding of Vinča ceramics.

The late Neolithic flat settlement at Opovo is located on a low knoll overlooking a then active meander of the Tamiš River, about $25 \mathrm{~km}$ north of Belgrade. During the 1980s five seasons of excavation recorded a total area of $340 \mathrm{~m}^{2}$ (Tringham et al. 1985; 1992), yielding three successive building horizons associated with late Vinča $\mathrm{C}$ and early Vinča D ceramics.

Thirteen radiocarbon measurements are available on animal bone (Orton 2012.Tab. 2) and unidentified 


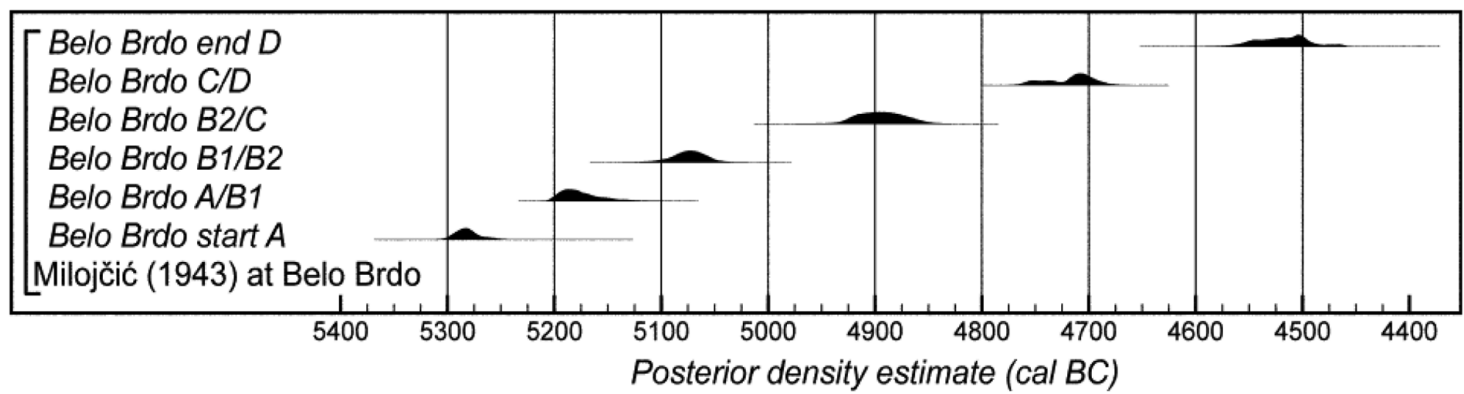

Fig. 15. Probability distributions of Milojčić (1943) ceramic phase boundaries at Vinča-Belo Brdo, derived from the model illustrated in Tasic et alii (2016a.Fig. 17).

charcoal (Tab. 2) from a sequence of building horizons (BH2 and 3) and associated pits. All 13 dates are in good agreement with the site stratigraphy and phasing, and the model has good overall agreement (Amodel: 115; Fig. 16).

The model indicates that activity associated with Vinča C pottery at Opovo began in 4960-4805 cal BC (95\% probability; Start Opovo C; Fig. 16), probably in $4915-4840$ cal BC (68\% probability), and that the use of Vinča $C$ pottery on the site ended in 4835-4695 cal BC (95\% probability; End Opovo C; Fig. 16), probably in 4820-4740 cal BC (68\% probability). It should be noted that there are currently no radiocarbon dates for the latest building horizon (BH 1) at Opovo and so settlement certainly continued after this time.
Located in the south-east suburb of Belgrade of the same name, the site of Banjica is a well-known late Neolithic settlement. It was situated on a plateau above the Banjica stream and was discovered during road construction in 1921 (Todorović, Cermanović 1961). The site has yielded five settlement horizons of wattle-and-daub structures and pits associated with Vinča D ceramics (Tripković 2007).

Two statistically consistent measurements $\left(\mathrm{T}^{\prime}=0.1\right.$; $\mathrm{T}^{\prime}(5 \%)=3.8 ; \mathrm{v}=1$; Ward, Wilson 1978) on bulk unidentified charcoal (one including charred grain) were obtained for features from Banjica associated with Vinča D pottery (Tab. 2). These provided termini post quos for the end of Vinča D here of 47704755 cal BC (1\% probability) or $4730-4355$ cal BC (94\% probability; GrN-1542), probably 4680-4635

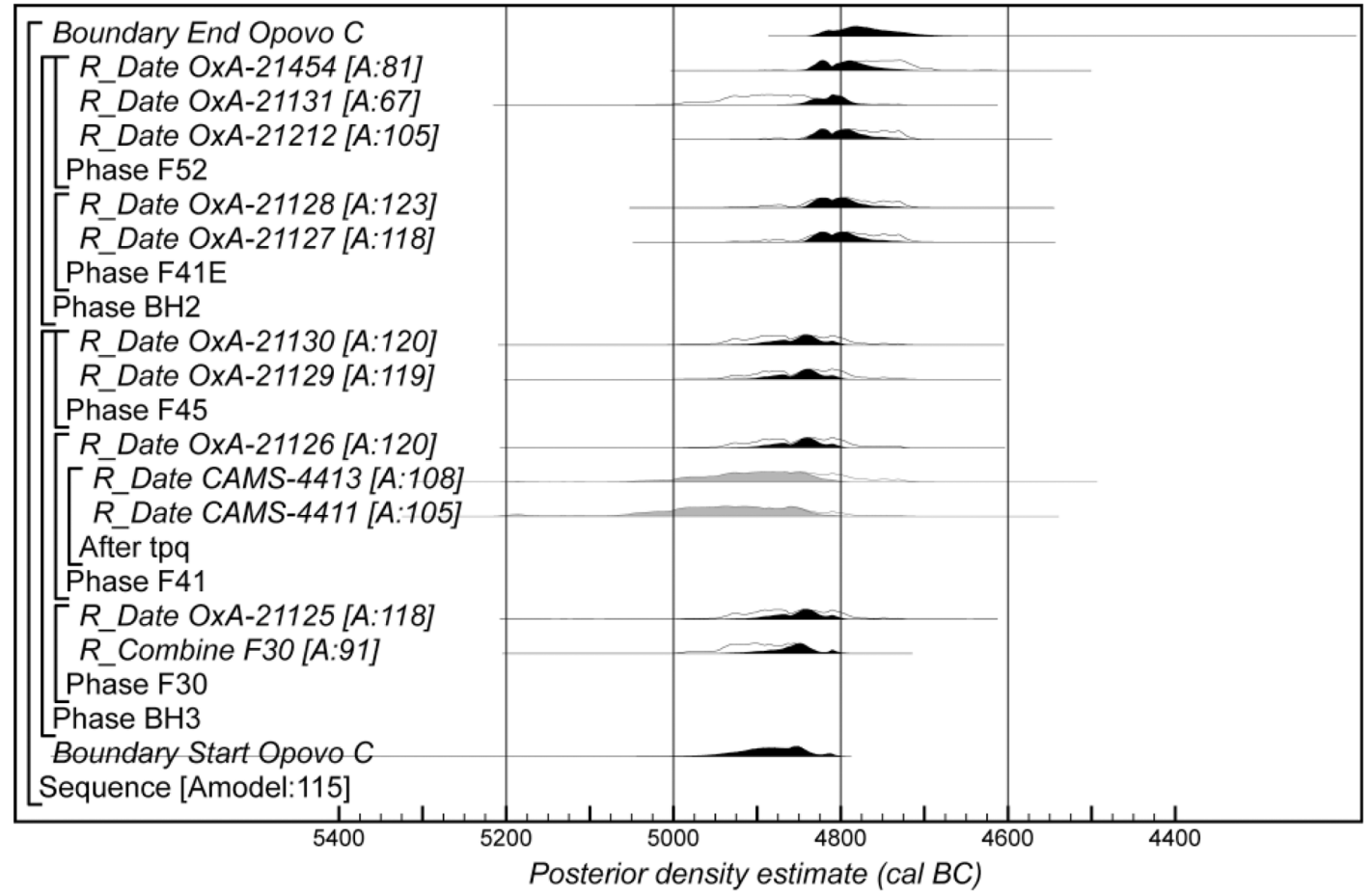

Fig. 16. Probability distributions of radiocarbon dates from Opovo. The format is identical to that of Figure 7. Grey tone indicates that the sample has a possible old-wood offset. The large square brackets down the left-hand side along with the OxCal keywords define the overall model exactly. 
cal BC ( $13 \%$ probability) or $4620-4455$ cal BC $(55 \%$ probability), and 4795-4320 cal BC (GrN-1536, 95\% probability), probably $4655-4640$ cal BC (2\% probability) or $4620-4365$ cal BC (66\% probability) 11 .

\section{Central Serbia12}

Located in central Serbia, south-west of Kragujevac, the settlement site of Grivac lies on the east bank of the Gruža River, on a wide terrace bounded by several streams. A chance discovery in 1950, it was excavated episodically between 1952 and 1994 (Bogdanovic 2004). The earliest phase of occupation has Starčevo pottery, and pre-dates a settlement associated with Vinča ceramics of phases A-C, which is itself sealed by an early Iron Age barrow cemetery (Bogdanović 1977).

Six radiocarbon dates, all on samples of unidentified bulk charcoal or 'burnt earth', can be associated with assemblages of Vinča ceramics (Tab. 2). Bln-870 provides a terminus post quem for the end of Vinča $\mathrm{A}$ of 5480-5040 cal BC ( $95 \%$ probability), probably of $5470-5400$ cal BC (12\% probability) or $5390-5205$ cal BC ( $56 \%$ probability). The latest of the five dates associated with Vinča C ceramics 13 provides a terminus post quem for the end of Vinča $\mathrm{C}$ of 4960-4530 cal BC (95\% probability; tpq Grivac C; Fig. 17), probably of $4880-4680$ cal BC (64\% probability) or 4640-4615 cal BC (4\% probability).

The site of Divostin (II) is situated in central Serbia, west of the town of Kragujevac, and on a slope between two streams in a landscape dominated by gentle hills. Small-scale excavations took place between 1967 and 1970 covering 1.65\% of the estimated total site area of 15ha (McPherron, Srejovic 1988). The earliest occupation on the site is associated with Starčevo pottery, but the majority of the excavated features belong to a later settlement defined by wattle and daub rectangular structures associated with late Vinča pottery.

Eleven radiocarbon dates were obtained on samples (seven unidentified bulk charcoal, one 'burnt earth' and three single animal bones) from a sequence of houses and pits associated with Vinča $C$ and D pottery (Tab. 1). Two dates on bulk charcoal (Bln-867 and BM-574) are far too young for their stratigraph- ic position within the described sequence, and have been excluded from the model. These samples probably contained a component of intrusive charcoal. The remaining nine measurements include two sets of replicates (repeat measurements on the same bulk sample). Two measurements on unidentified charcoal from pit F117 are statistically consistent (Bln-865 and Bln-865a; T' $\left.=0.2 ; T^{\prime}(5 \%)=3.8 ; v=1\right)$, as are three measurements, also on unidentified charcoal, from pit 20 (F121) (Z-336a, Z-336b and Bln$\left.898 ; \mathrm{T}^{\prime}=2.1 ; \mathrm{T}^{\prime}(5 \%)=6.0 ; \mathrm{v}=2\right)$.

The model which combines these radiocarbon dates with the ceramic phasing has good overall agreement (Amodel: 113; Fig. 18), although all the samples that can be associated with Vinča $\mathrm{C}$ ceramics are of unidentified charcoal and so only provide termini post quos for the end of this phase. This model suggests that the transition between Vinča C and D ceramics at Divostin occurred in 4830-4600 cal BC (95\% probability; Divostin C/D; Fig. 18), probably 4740-4635 cal BC (68\% probability) and the use of Vinča D ceramics ended in 4710-4320 cal BC (95\% probability; End Divostin D; Fig. 18), probably 46754535 cal BC (68\% probability).

\section{The Morava valley and southwards}

The site of Anzabegovo is located in the eastern part of FYR of Macedonia, in an area known as 0vče Pole. It was discovered by chance during the construction of a railway line in the early $1960 \mathrm{~s}$, with the main excavations taking place in 1969 and 1970 (Gimbutas 1974). The multi-period settlement was first established in the early Neolithic, with activity on site occurring into the Roman period.

Two statistically consistent measurements (LJ-2329 and LJ-2411: $\left.\mathrm{T}^{\prime}=1.0 ; \mathrm{T}^{\prime}(5 \%)=3.8 ; \mathrm{v}=1\right)$ on unidentified bulk charcoal were obtained for features associated with Vinča B pottery (Tab. 2). Given the potential for the sample to have contained a component of old wood, LJ-2329 provides a terminus post quem for the presence of Vinča B ceramics at Anzabegovo of $5320-5025$ cal BC ( $95 \%$ probability), probably of $5300-5205$ cal BC (39\% probability) or $5165-5115$ cal BC (17\% probability) or $5110-5075$ cal BC (11\% probability).

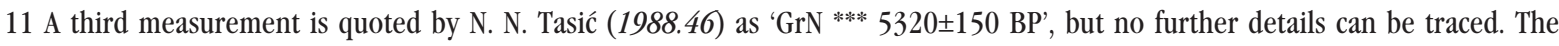
Groningen laboratory has no record of this measurement, and so it was certainly produced elsewhere. It calibrates to 44553890 cal BC (90\% probability) or 3885-3795 cal BC (5\% probability).

12 Two measurements have been published by Gimbutas (1976.Tab. IV) as being from Medvednjak in central Serbia. Bln-480, however, is from Ószentiván, Hungary (Kohl, Quitta 1970.411) and LJ-2523 is from Šventoji, Lithuania (Linick 1977.27).

13 Z-1507 is clearly much later than the other samples from this phase and has been excluded from this analysis; it is likely that the bulk sample contained an element of intrusive later charcoal. 


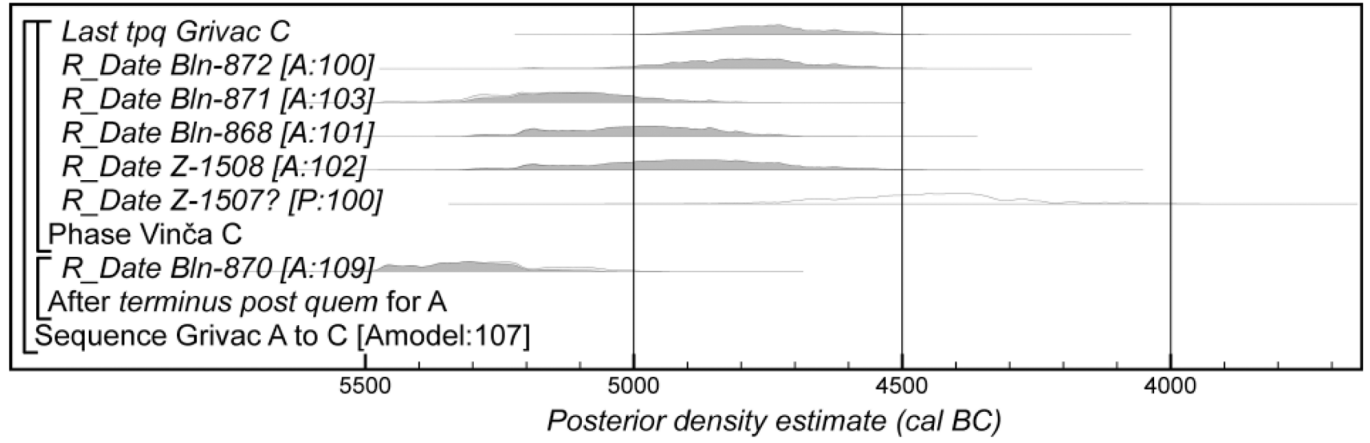

Fig. 17. Probability distributions of radiocarbon dates from Grivac. The format is identical to that of Figure 7. Grey tone indicates that the sample has a possible old-wood offset. The large square brackets down the left-hand side along with the OxCal keywords define the overall model exactly.

The site of Belovode in Veliko Laole lies to the west of River Mlava, on one of its smaller tributaries. It was discovered by chance in the 1960s. The settlement was located on an ellipsoid plateau, barely $10 \mathrm{~km}$ to the east of the Velika Morava River, and is cut in half by a small stream named Belovode (Šljivar, Jacanovic 1996). The site is multi-period, with the earliest habitation occurring during the Starčevo period, followed by a longer phase of late Neolithic Vinča occupation and ending in the Late Bronze Age. The first systematic excavations took place in 1994 and continued episodically until 2015 .

Nine radiocarbon dates were obtained on samples of single animal bones and antlers from a sequence of houses and associated features with Vinča A to C pottery (Borić 2009; Tab. 2). One date (0xA-14678) from the top of the sequence is far too late and almost certainly belongs to a later phase of activity and is excluded from the model. Three dates (0xA-14680,
-14683 and -14700 ), with poor individual agreement with their relative stratigraphic positions, work well with the model presented in Figure 19 if treated as termini post quos (interpreted as residual animal bone within their respective contexts). If this interpretation is applied then the model, based on the stratigraphy, pottery phasing (A to $\mathrm{C}$ ) and the radiocarbon dates, has good overall agreement (Amodel: 102; Fig. 19).

The model indicates that the activity, associated with Vinča A to C pottery, started at Belovode in 57955230 cal BC (95\% probability; Start Belovode A; Fig. 19), probably in 5515-5310 cal BC (68\% probability); that the transition from Vinča A to B occurred in 5365-5075 cal BC (95\% probability; Belovode $A / B$; Fig. 19), probably in 5320-5165 cal BC (68\% probability); that the transition from Vinča $B$ to $C$ occurred in 5150-4645 cal BC (95\% probability; Belovode B/C; Fig. 19), probably in 5050-4735 cal

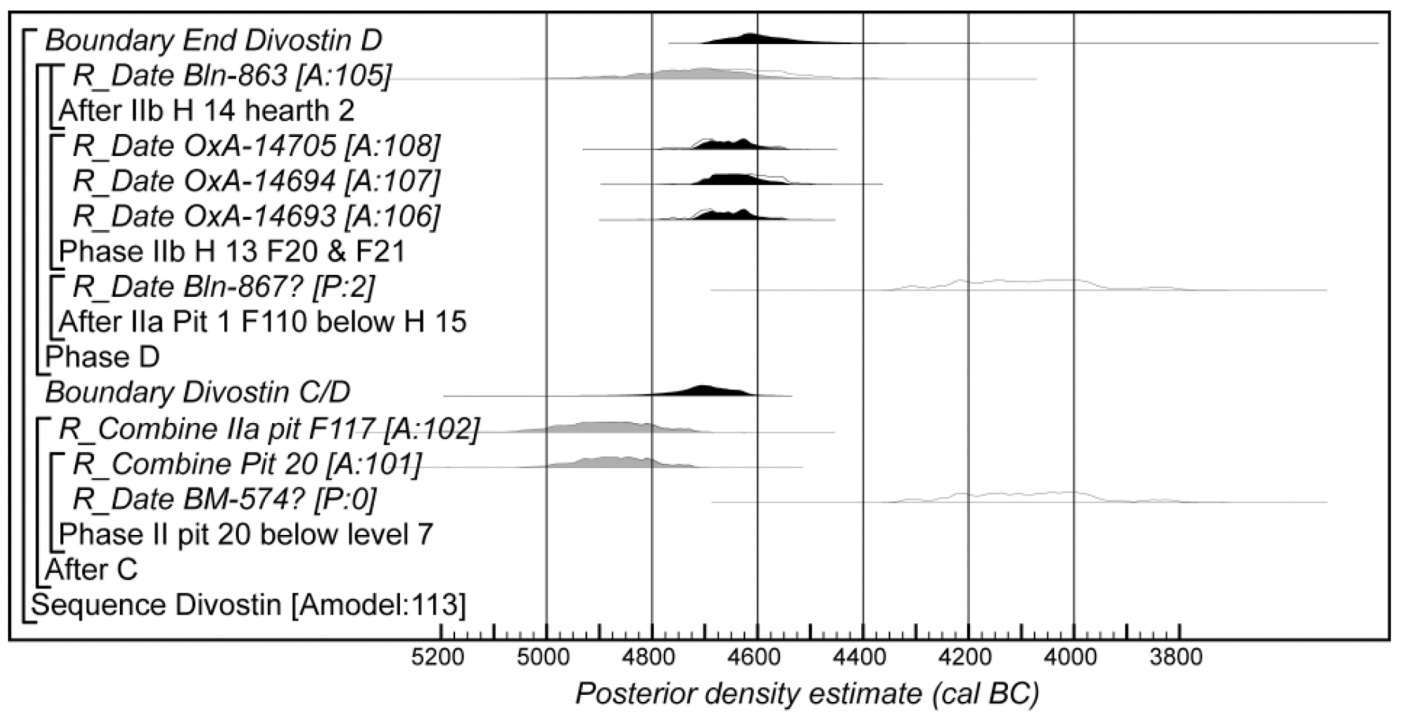

Fig. 18. Probability distributions of radiocarbon dates from Divostin. The format is identical to that of Figure 7. Grey tone indicates that the sample has a possible old-wood offset. The large square brackets down the left-hand side along with the OxCal keywords define the overall model exactly. 
$B C(68 \%$ probability). The use of Vinča $\mathrm{C}$ ceramics at Belovode ended in 4775-4205 cal BC (95\% probability; End Belovode C; Fig. 19), probably in 47054495 cal BC (68\% probability).

Located in a village west of the town of Prokuplje, the site of Pločnik lies on an elevated terrace of the Toplica River. It was discovered in the 1920s during the construction of a railway line and was excavated episodically until 2013 (Stalio 1964; 1973). The site is best known for the find of approx. $17 \mathrm{~kg}$ of copper implements excavated from buildings and hoards associated with a late phase of Vinča culture (Šljivar et al. 2010).

Eight radiocarbon measurements, all on single animal bones, were obtained for features associated with houses within the settlement (Tab. 2). The dated features contained Vinča B pottery and 'Gradac' pottery. In this area the site begins with the use of Vinča B1 (D. Šljivar, pers. comm.), and all the dated samples are from contexts below the 'Gradac' layer except for 0xA-14685 (Borić 2009.Figs. 2223). Samples from sequences of deposits were dated in trenches 14 and 15, and all the radiocarbon dates are in good agreement with these stratigraphic sequences and the pottery phasing (Amodel: 102; Fig. 20).
The first use of Vinča B1 ceramics at Pločnik occurred in 5350-5060 cal BC (95\% probability; Start Pločnik B1; Fig. 20), probably in 5240-5110 cal BC (68\% probability). Vinča B ceramics ended here in 5030-4755 cal BC (95\% probability; End Pločnik B2; Fig. 20) probably in 4985-4860 cal BC $(68 \%$ probability). Trench 16 contained features associated with 'Gradac' pottery. A single radiocarbon sample associated with this ceramic phase provides a terminus ante quem for the start of Milojčic phase $\mathrm{C}$ and a terminus post quem for the end of Milojčić phase $\mathrm{D}$ at Pločnik of 4710-4530 cal BC (95\% probability; OxA-14685; Tab. 2), probably of 4685-4630 cal BC (31\% probability) or $4625-4555$ cal BC (37\% probability).

The site of Oreškovica lies on a hill dominating the surrounding territory around the village of the same name. It is approx. 6ha in size, and is surrounded by at least two enclosure ditches. It is a single-phase settlement associated with Vinča B pottery. Even though it was known by the mid-1970s it was only excavated for the first time in 2013 (Borić et al. in preparation).

Six radiocarbon dates, all on single samples of animal bone (two of them articulating) are currently available (Tab. 2). A model combining these results

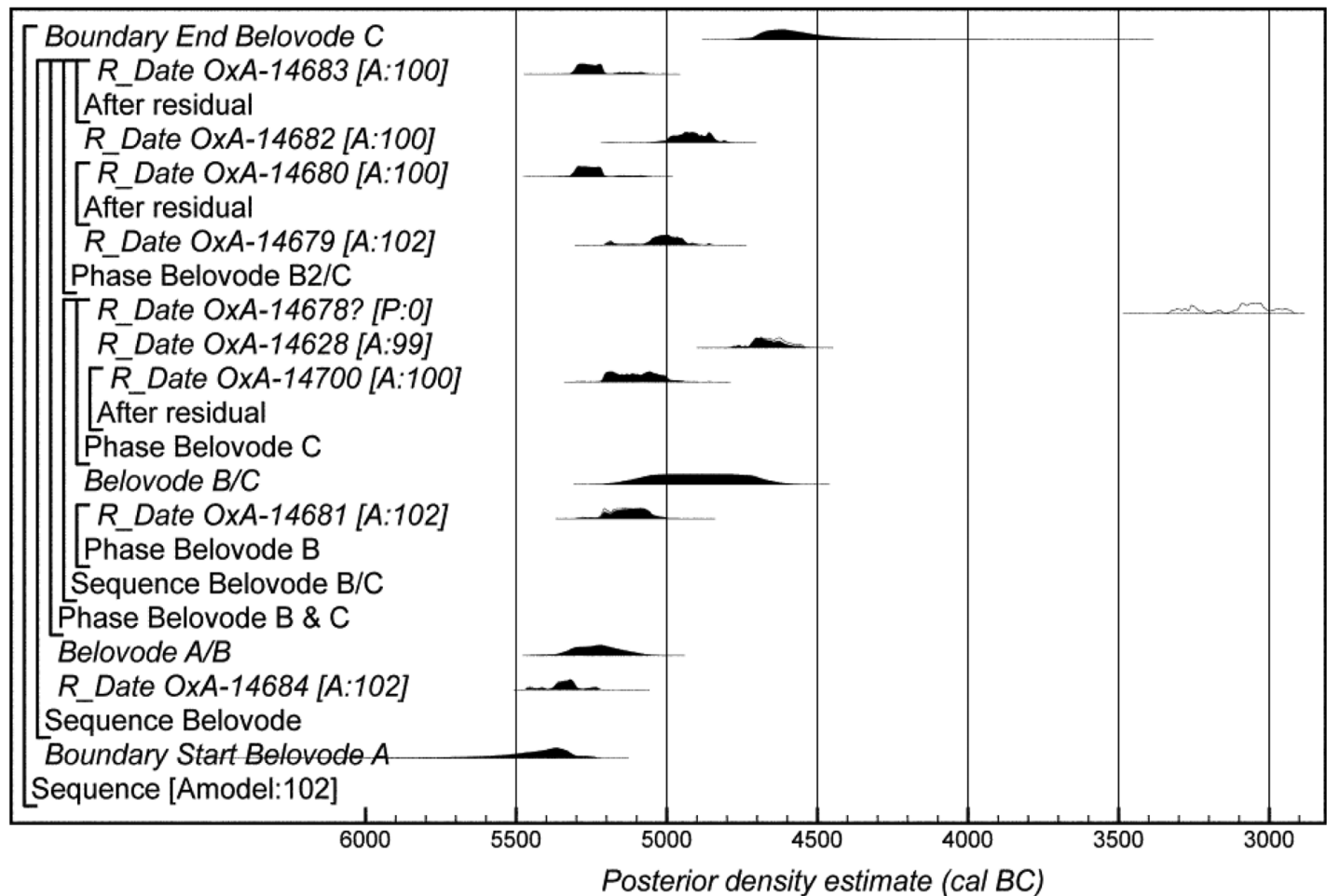

Fig. 19. Probability distributions of radiocarbon dates from Belovode. The format is identical to that of Figure 7. The large square brackets down the left-hand side along with the OxCal keywords define the overall model exactly. 


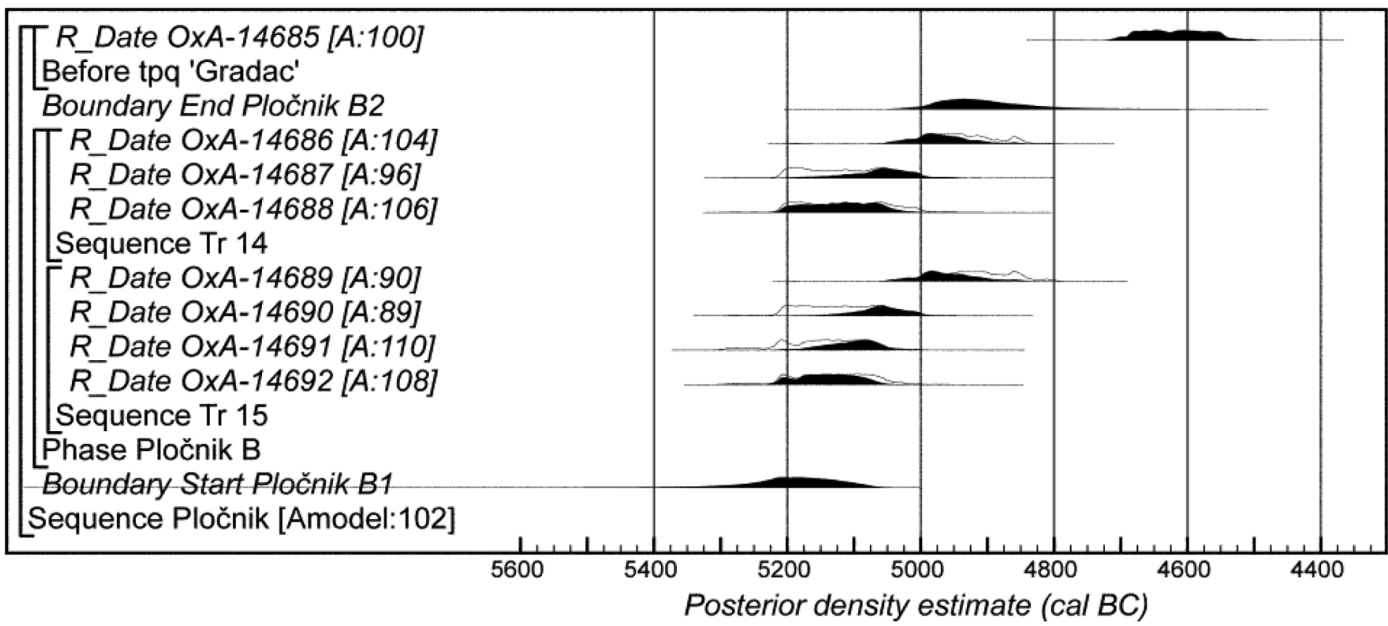

Fig. 20. Probability distributions of radiocarbon dates from Pločnik. The format is identical to that of Figure 7. The large square brackets down the left-hand side along with the OxCal keywords define the overall model exactly.

with the stratigraphic sequence is shown in Fig. 21, and has good overall agreement (Amodel: 105; Fig. 21). This suggests that the settlement at Oreškovica (and so Vinča B ceramics) began in 5400-5080 cal BC (95\% probability; Start Oreškovica B; Fig. 21), probably in 5335-5210 cal BC (67\% probability) or 5165-5155 cal BC (1\% probability), and ended in 5215-4935 cal BC (95\% probability; End Oreškovica B; Fig. 21), probably in 5200-5180 cal BC (4\% probability) or 5165-5030 cal BC (64\% probability).

Selevac-Staro Selo site lies in the Šumadija area, to the west of the lowest part of the Velika Morava River valley, barely $22 \mathrm{~km}$ south of its confluence with the Danube (Tringham, Krstic 1990a). The site is located $4.8 \mathrm{~km}$ east of the modern village of the same name on elevated ground west of the river.
The site was recognised in 1968, with small-scale excavations taking place until 1970 and again in 1973. The Selevac Archaeological Project ran from 1976 until 1981, and yielded settlement remains of the Late Neolithic Vinča period.

Twelve radiocarbon dates for Selevac were obtained on samples (bulk charcoal and bulk cereal grain) from a sequence of houses and associated features with Vinča B1 to C pottery (Tab. 2). We have used the ceramic phasing for this sequence presented by Schier (1995.Figs. 144-5), although unfortunately all the dates associated with Vinča B2 and C ceramics are on unidentified charcoal and so can only be included in the model as termini post quos. This model is shown in Fig. 22, which has good agreement (Amodel: 100). Generally, measurements from the Rudjer Bošković Institute, Zagreb, are likely to

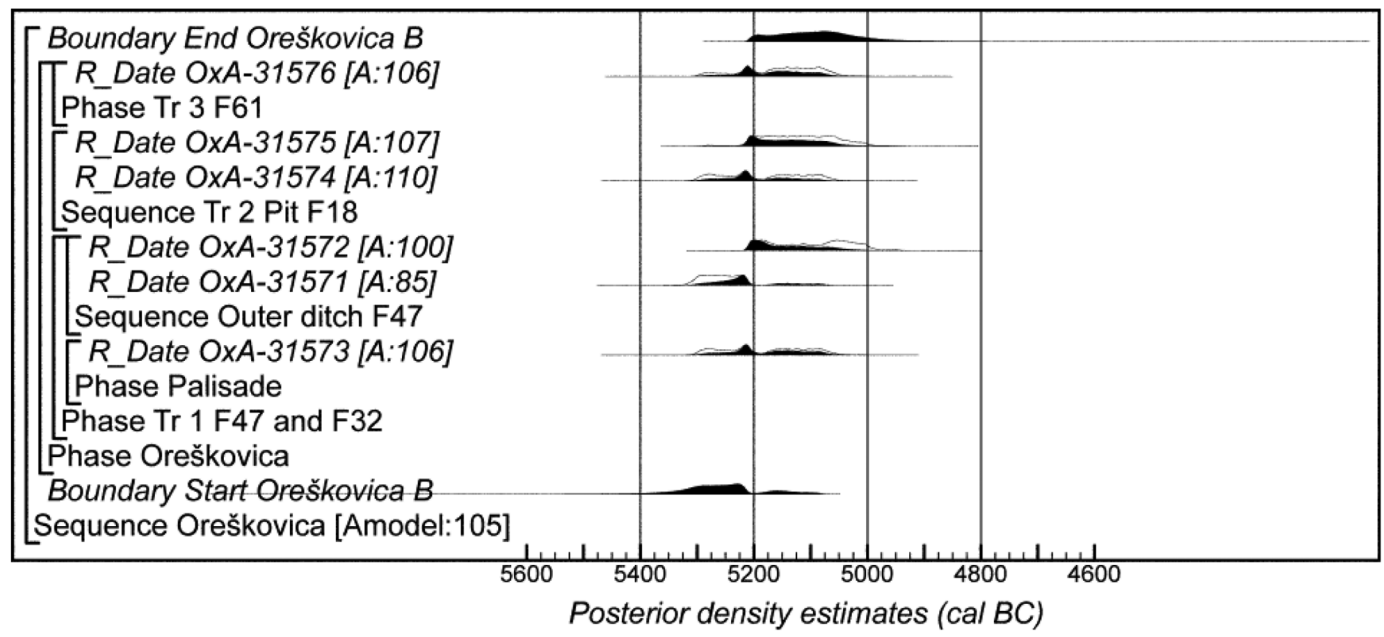

Fig. 21. Probability distributions of radiocarbon dates from Oreškovica. The format is identical to that of Figure 7. The large square brackets down the left-hand side along with the OxCal keywords define the overall model exactly. 
be on average 77 years too young (Horvatinčić et al. 1990.299). In this case, however, it can be noted that the two measurements in question (Z-233a-b) are statistically consistent with a third from La Jolla $\left(\mathrm{LJ}-2521 ; \mathrm{T}^{\prime}=0.4 ; \mathrm{T}^{\prime}(5 \%)=6.0 ; \mathrm{v}=2\right)$ and so they are probably accurate.

The model indicates that this activity, associated with Vinča B1 pottery, started in 6800-6685 cal BC $(2 \%$ probability; Start Selevac B1; Fig. 22) or 6340-4960 cal BC (93\% probability), probably in 5525-5010 cal BC (68\% probability). The transition between Vinča B1 and B2 occurred here in 5210-3585 cal BC (95\% probability; Selevac B1/B2; Fig. 22), probably in 5165-4655 cal BC (68\% probability). The dated occupation at Selevac ended in 4580-2460 cal BC (78\% probability; End Selevac C; Fig. 22) or 2195-1495 cal BC (17\% probability), probably in 4565-3190 cal BC (61\% probability) or 1770-1495 cal BC (7\% probability).

The site of Predionica is located in a suburb of Priština in Kosovo. It was excavated in 1955 and 1956 in advance of the construction of a factory building. It yielded a late Neolithic settlement with three building horizons (Galovic 1959). A single sample of oak charcoal was dated from a fire installation associated with Vinča A ceramics, and provides a terminus post quem of $5470-5400$ cal BC (6\% probability; Bln-435) or $5390-5045$ cal BC (89\% probability), probably of $5360-5205$ cal BC ( $57 \%$ probability) or $5165-5135$ cal BC (5\% probability) or $5130-5115$ cal BC (2\% probability) or $5110-5100$ cal BC (1\% probability) or $5095-5075 \mathrm{cal} \mathrm{BC} \mathrm{(3 \%} \mathrm{probability)}$ for the end of Vinča $A$ at this location.

The site of Valač is located in the north-west part of Kosovo, near the town of Kosovska Mitrovica. The site is located on a terraced hill on the edge of the Ibar River valley, and it appears to have been defended by a palisade and a stone wall (N. Tasic 1960). It was excavated briefly in 1957 . A single measurement on a bulk sample of charred acorns and peas from a pit associated with Vinča D ceramics dates this assemblage to 4960-4545 cal BC (95\% probability; Bln-436), probably to $4900-4865$ cal BC (7\% probability) or $4855-4685$ cal BC (61\% probability).

Beran Krš is located on a dominant ridge on the left bank of the river Lim, approx. $3 \mathrm{~km}$ from the town of Berane in Montenegro. Small test trenches were dug in 1961, but the main research excavations were undertaken in 1975 and 1976. The settlement consisted of several building horizons belonging to the Vinča period (Marković 1985).

Two measurements on unidentified bulk charcoal are available from two stratigraphically related deposits (Tab. 2). The published contextual details, how-

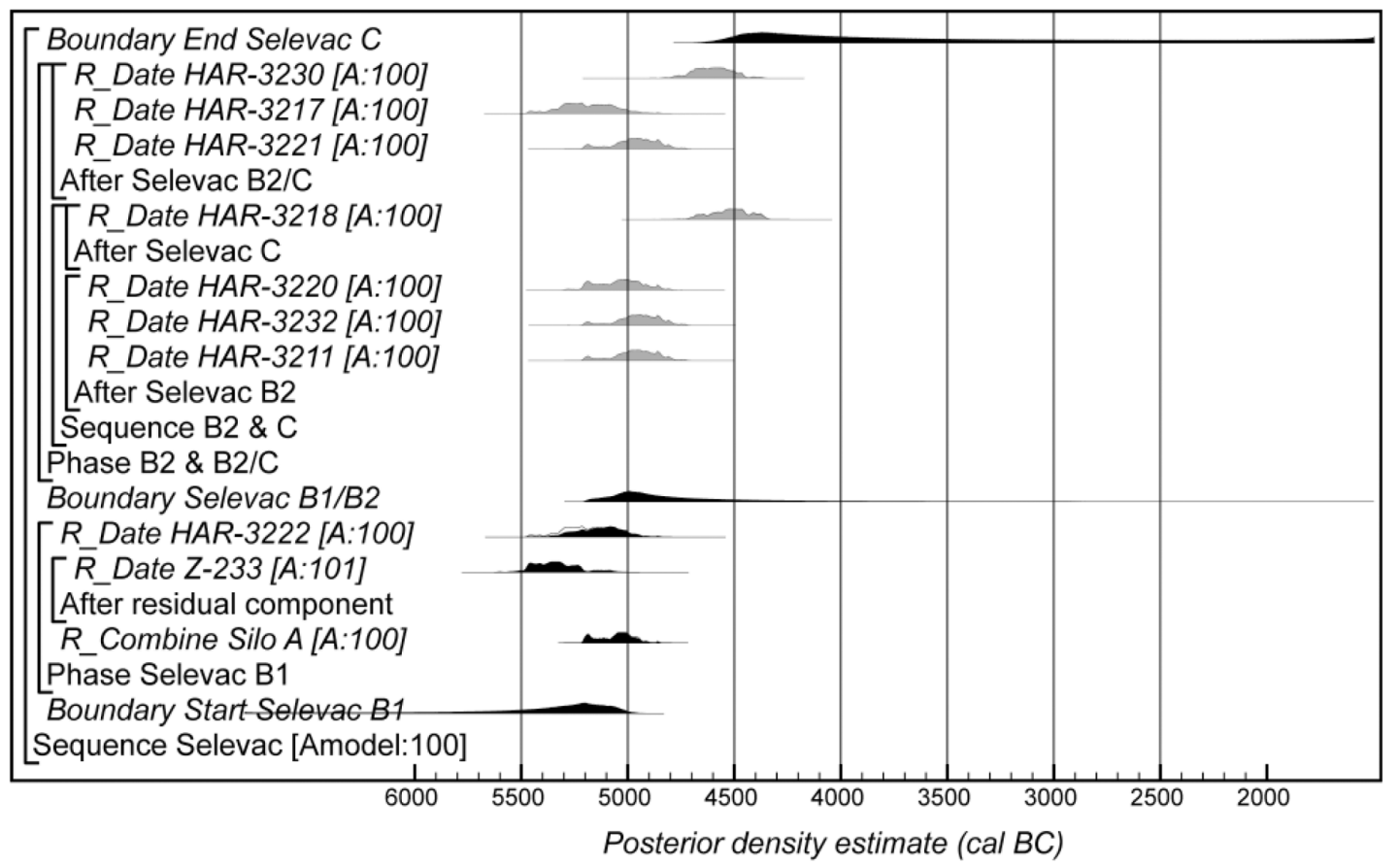

Fig. 22. Probability distributions of radiocarbon dates from Selevac. The format is identical to that of Figure 7. Grey tone indicates that the sample has a possible old-wood offset. The large square brackets down the left-hand side along with the OxCal keywords define the overall model exactly. 
ever, differ. Z-491 is attributed to Level VII and Z492 to Level XIII (Srdoč et al. 1977.474), but also to Levels III and IV/Horizon IIa (Marković 1985.70). Here, we follow Čedomir Marković (1985.72) in interpreting both dates as termini post quos for the end of Vinča $C$ ceramics at this location, of 52055165 cal BC (2\% probability; Z-491) or 5075-4765 cal BC (93\% probability), probably of 5000-4840 cal BC (68\% probability), and of 5210-5160 cal BC ( $1 \%$ probability; Z-492) or 5080-4440 cal BC (92\% probability) or $4425-4370$ cal BC (2\% probability), probably of 4930-4920 cal BC (1\% probability) or 49104545 cal BC (67\% probability). It should be noted that both measurements are from the Rudjer Bošković Institute, Zagreb, and it is likely that the measurements are on average 77 radiocarbon years too young (Horvatinčić et al. 1990.299).

The site of Donje Vranje in the southern Morava valley was excavated in advance of road construction in June 2013 (Kapuran et al. 2016). Several pits containing Vinča B2 ceramics were recorded. A single radiocarbon date on a disarticulated animal bone was dated from pit 1, providing a date of 5295-5240 cal BC (9\% probability; SUERC-57927) or 5235-5050 cal BC ( $86 \%$ probability), probably of $5220-5200 \mathrm{cal}$ BC ( $10 \%$ probability) or $5175-5070 \mathrm{cal} \mathrm{BC}(58 \%$ probability) for the use of Vinča $\mathrm{B} 2$ ceramics on the site.

\section{The Danube downstream of Vinča-Belo Brdo}

A single sample of unidentified charcoal has been dated from pit 21 at Gornea, providing a terminus post quem of $4895-4865$ cal BC (2\% probability; BM-1124) or $4850-4585$ cal BC (93\% probability), probably of $4825-4815$ cal BC (3\% probability) or 4805-4685 cal BC (65\% probability) for the associated assemblage of Vinča A ceramics (Burleigh, Hewson 1979.350). A bulk sample of charred grain from Liubcova (László 1997) has been dated from a context associated with Vinča B2 pottery, dating it to 5320-4905 cal BC (95\% probability; Bln-2133), probably to $5225-5000 \mathrm{cal} \mathrm{BC}$ (68\% probability).

The site of Rudna Glava is located in the village of the same name on a steep slope above it. The loca- tion is about $20 \mathrm{~km}$ south of the Danube in the area of the Iron Gorge (Jovanovic 1982). Rudna Glava is best known for its early copper metallurgy and was the first copper ore mine to be excavated in the Balkans. Discovered in the mid-1960s, the first archaeological survey took place in 1968 , followed by several seasons of excavations which uncovered multiple prehistoric shafts cut vertically into the cliff face.

Fourteen radiocarbon measurements are available on samples from Rudna Glava (Borić 2009.Tab. 1; Burleigh et al. 1982.255), but only eight of these appear to be associated with Vinča ceramics 14 . These have been assigned to the Gradac phase (Jovanovic 1982; 1994) which here we equate broadly with Milojčić phases $\mathrm{C}$ and $\mathrm{D}$. The relationships between the dated material and the ceramics, however, are not straightforward. The deposition of hoards in which the best preserved and diagnostically most sensitive vessels were found was probably structured and possibly ritualised. This may have taken place after a long period of use of the mining shafts, and it is also possible that the hoards represent an accumulation over time rather than single events. In these circumstances, we have interpreted the start of the period when Vinča ceramics were deposited at Rudna Glava as a terminus post quem for the start of Milojčić phase $\mathrm{C}$, and the end of the period when Vinča ceramics were deposited at Rudna Glava as a terminus post quem for the end of Milojčic phase D.

A model for the mining activities at Rudna Glava associated with Vinča C and D pottery is shown in Figure 23. A weighted mean has been taken on the statistically consistent measurements on antler RG8 before incorporation in the model (0xA-14624-5; $\left.\mathrm{T}^{\prime}=0.2, \mathrm{~T}^{\prime}(5 \%)=3.8, \mathrm{v}=1\right)$, which has good overall agreement (Amodel: 97; Fig. 23). This suggests that Vinča $C$ ceramics appeared here after 5745 5240 cal BC (95\% probability; tpq Rudna Glava C; Fig. 23), probably after 5505-5325 cal BC (68\% probability), and suggests that Vinča $\mathrm{D}$ ceramics were last deposited here after 4920-4445 cal BC (95\% probability; tpq Rudna Glava D; Fig. 23), probably after 4870-4685 cal BC (68\% probability).

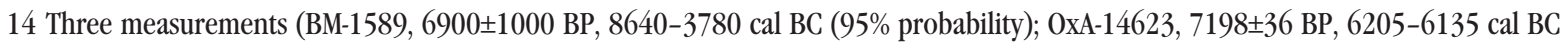
(8\% probability) or $6115-5995$ cal BC (87\% probability); OxA-14627, 6665 36 BP, $5645-5520$ cal BC (95\% probability)) appear to indicate use of the mining complex in the earlier part of the seventh millennium cal BC. The collagen in all these samples, however, was poorly preserved and so there must be some doubt over the accuracy of these dates. One further sample appears to indicate further use of the mines in the Copper Age (0xA-14676, 4273 $\pm 32 \mathrm{BP}, 3005-2990$ cal BC (1\% probability) or 29302865 cal BC ( $91 \%$ probability) or 2805-2775 cal BC (3\% probability)). Two of the Vinča period dates do not appear to be associated with ceramics and are not included in the model presented here (0xA-16585, 5816 $\pm 35 \mathrm{BP}, 4780-4550 \mathrm{cal} \mathrm{BC}(95 \%$ probability); OxA-14699, 5974 \pm 39 BP, 4975-4765 cal BC (94\% probability) or 4755-4740 cal BC (1\% probability)). 


\section{A timescape for Vinča pottery}

We begin by constructing a chronological model, in which the use of Vinča ceramics forms a continuous and relatively constant phase of activity, opening with the start of Milojčić phase A and ending with the end of Milojčić phase D (Fig. 24). The start of Milojčić phase $\mathrm{A}$ is constrained to be earlier than the start of Milojčić phase B1 in this model; the start of $\mathrm{B} 1$ is constrained to be earlier than the start of $\mathrm{B} 2$; the start of $\mathrm{B} 2$ is constrained to be earlier than the start of $\mathrm{C}$; and the start of $\mathrm{C}$ is constrained to be earlier than the start of D. The start of phase B (sites where we are unsure whether the ceramics are phase $\mathrm{B} 1$ or $\mathrm{B} 2$ ) is also constrained to be later than the start of Milojčić phase A. Since we are uncertain whether the transition from one phase to the next happened at the same time everywhere, we have not constrained the end of phase A to be earlier than the start of phase B1, for example. We have however constrained the end of Milojčic phase A to be earlier than the start of Milojčić phase $\mathrm{C}$ and the end of Milojčić phases B1 and B2 (and the combined phase B) to be earlier than the start of Milojčić phase D. We believe these constraints to be reasonable, since there appear to be no closed assemblages containing both Vinča A and Vinča C pottery, or both Vinča B and Vinča D pottery 15.

This approach means that we can examine whether there is any overlap between the use of ceramics assigned to successive phases in the Miljočić scheme. Where there are more than three radiocarbon dates for a site, key parameters from the site-based mod- els described above are imported as likelihoods in the synthetic models. For example, in the model component relating to the currency of Vinča A ceramics (Fig. 25), Vinča Belo Brdo is represented by two parameters - Belo Brdo start A and Belo Brdo A/B1 - which means that the 19 radiocarbon measurements from samples recovered between the depths of $9.3 \mathrm{~m}$ and $8.0 \mathrm{~m}$ in the Vasić sequence are not disproportionally weighted in the model in comparison with sites with fewer dates. Where there are one or two dates on short-lived materials securely associated with a ceramic phase, these are included fully in the model (e.g., Deb-2579 from Satchinez; Fig. 25). In other cases, where there are one or two results on charred plant material that might have included a component of old wood, the dates are modelled as termini post quos for the end of the phase. These distributions are shown in grey (e.g., Bln-435, a sample of oak charcoal from Predionica; Fig. 25). In a few cases, dates are clearly misfits, and have been excluded from the modelling (e.g., BM-1124, a sample of unidentified charcoal from Gornea) which is more than 400 years later than any other sample associated with Vinča A ceramics and must have contained component of intrusive material. These distributions are shown in red and the parameter name is followed by '?'.

The overall form of this chronological model (Model 1 ) is illustrated in Fig. 24 with its components illustrated in Figs. 25, 27, 29, 31-32 and 35. It is defined exactly by the CQL2 keywords and structure provided as supplementary information (Vinca_Milojcic_ Model_1.oxcal).

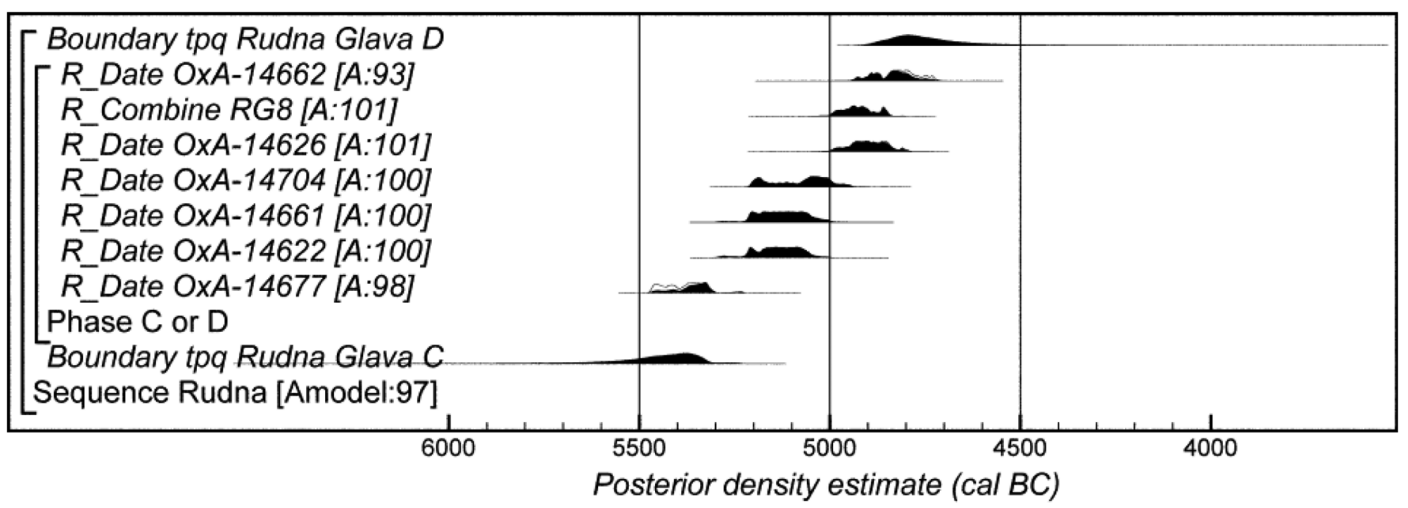

Fig. 23. Probability distributions of radiocarbon dates from Rudna Glava. The format is identical to that of Figure 7. The large square brackets down the left-hand side along with the OxCal keywords define the overall model exactly.

15 As part of the preliminary modelling undertaken for this study, we constructed a model which included no relative sequence between the phases of Vinča ceramics. This model suggests that start $A$ is earlier than start B1 (87\% probable), that start B1 is earlier than start B2 (95\% probable), that start B2 is earlier than start C (96\% probable), and that start C is earlier than start $D$ ( $88 \%$ probable). This model also suggests that end $A$ is earlier than start C $(96 \%$ probable), and that end $B 1$ and end $B 2$ are earlier than start $D(85 \%$ and $62 \%$ probable respectively). 


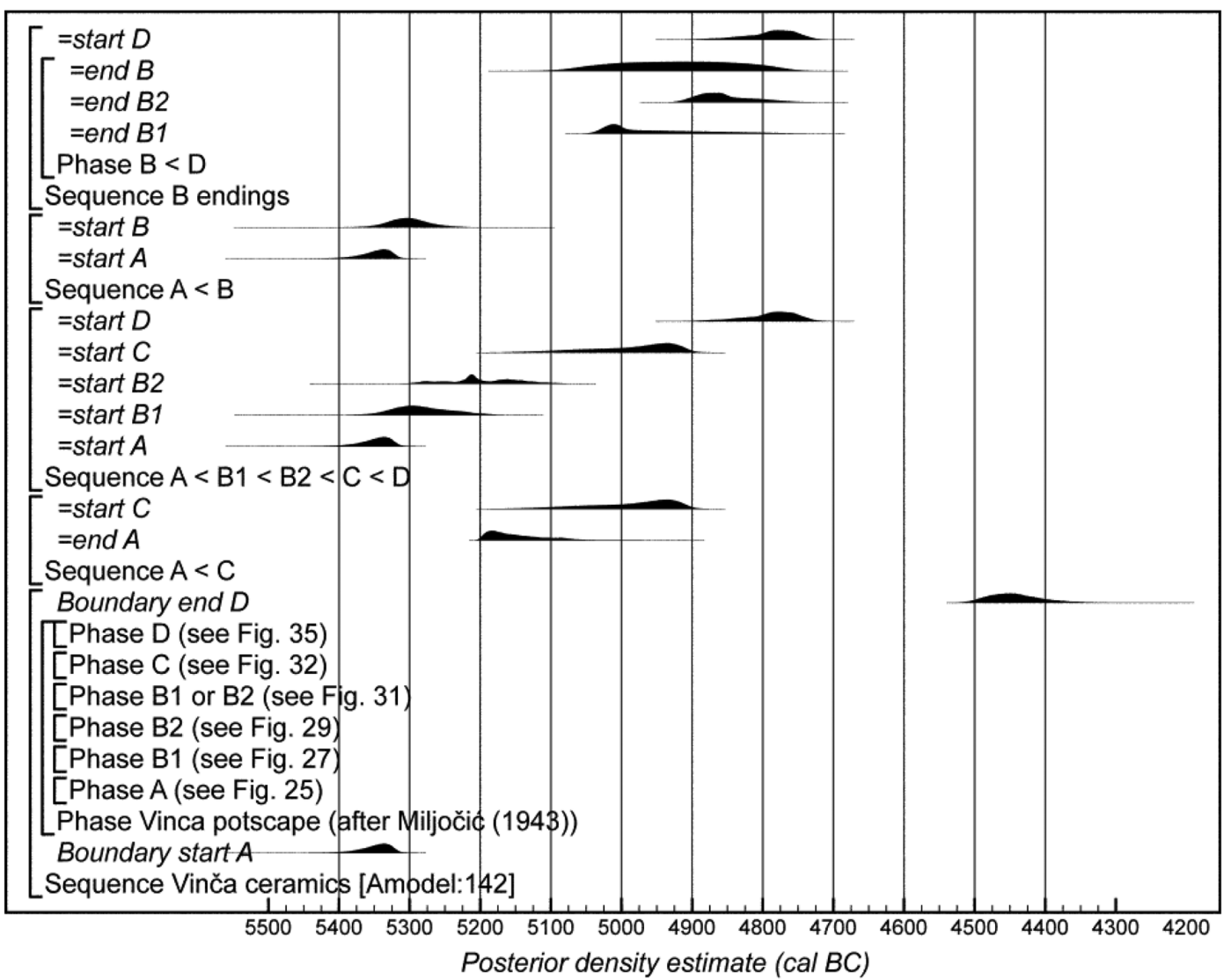

Fig. 24. Overall form of the chronological model for the phasing of Vinča pottery proposed by Milojčić (1943) (Model 1). The format is identical to that of Figure 7. Components of this model are illustrated in Figs. 25, 27, 29, 31-32 and 35. The model is defined exactly by the 0xCal keywords and structure provided as supplementary information (Vinca_Milojcic_Model_1.oxcal).

The component of this model relating to the currency of Vinča A ceramics is shown in Fig. 25. It suggests that this ceramic phase begun in 5405-5310 cal BC (95\% probability; start A; Fig. 25), probably in 5365-5320 cal BC (68\% probability). The use of Vinča A ceramics ended in 5205-5070 cal BC $(95 \%$ probability; end A; Fig. 25), probably in 5200-5130 cal BC (68\% probability). Vinča A ceramics were thus in use for a period of 125-295 years (95\% probability; duration A; Fig. 38), probably for 140-230 years (68\% probability).

The Vinča network appears to have been established very quickly - within the space of one or two human generations. Sites as widely spaced as SzederkényKukorica-dúló and Belovode were probably founded in the generation before 5300 cal BC (Figs. 25 and 26). Other sites came into being over the succeeding century, including the Vinča settlement at Belo Brdo itself, which as suspected by Lazarovici (1979.105106, Tab. 7, 122-123) was not among the very first foundations. We have modelled radiocarbon dates from sites from the northern and the western periphery of the Vinča A network, as well as from its cen- tre. Although there are known sites with characteristic Vinča A forms in the southern and eastern periphery of the network, either they are lacking radiocarbon dates, or the association between pottery phases and radiocarbon dates is not secure. Currently Szederkény-Kukorica-dúló in the extreme northwest of the network is the earliest known dated site with Vinča ceramics (on present evidence it is $60 \%$ probable that it was established before Belovode: Fig. 25). It is not possible to disentangle the direction of innovation without dating many more sites at the generational precision provided by ToTL at Szederkény-Kukorica-dúló, Versend and Belo Brdo. The network was established so quickly that we need to trace the foundations of different sites to within a few decades across the latter part of the $54^{\text {th }}$ and the earlier part of the $53^{\text {rd }}$ century cal BC.

Recent formal modelling of the earliest (älteste) LBK, however, allows us to compare the date when the Vinča network was established with the time when LBK ceramics rapidly spread across much of north and north-west Europe. Jakucs et alii (2016. Figs. 17-22) present three alternative models for 


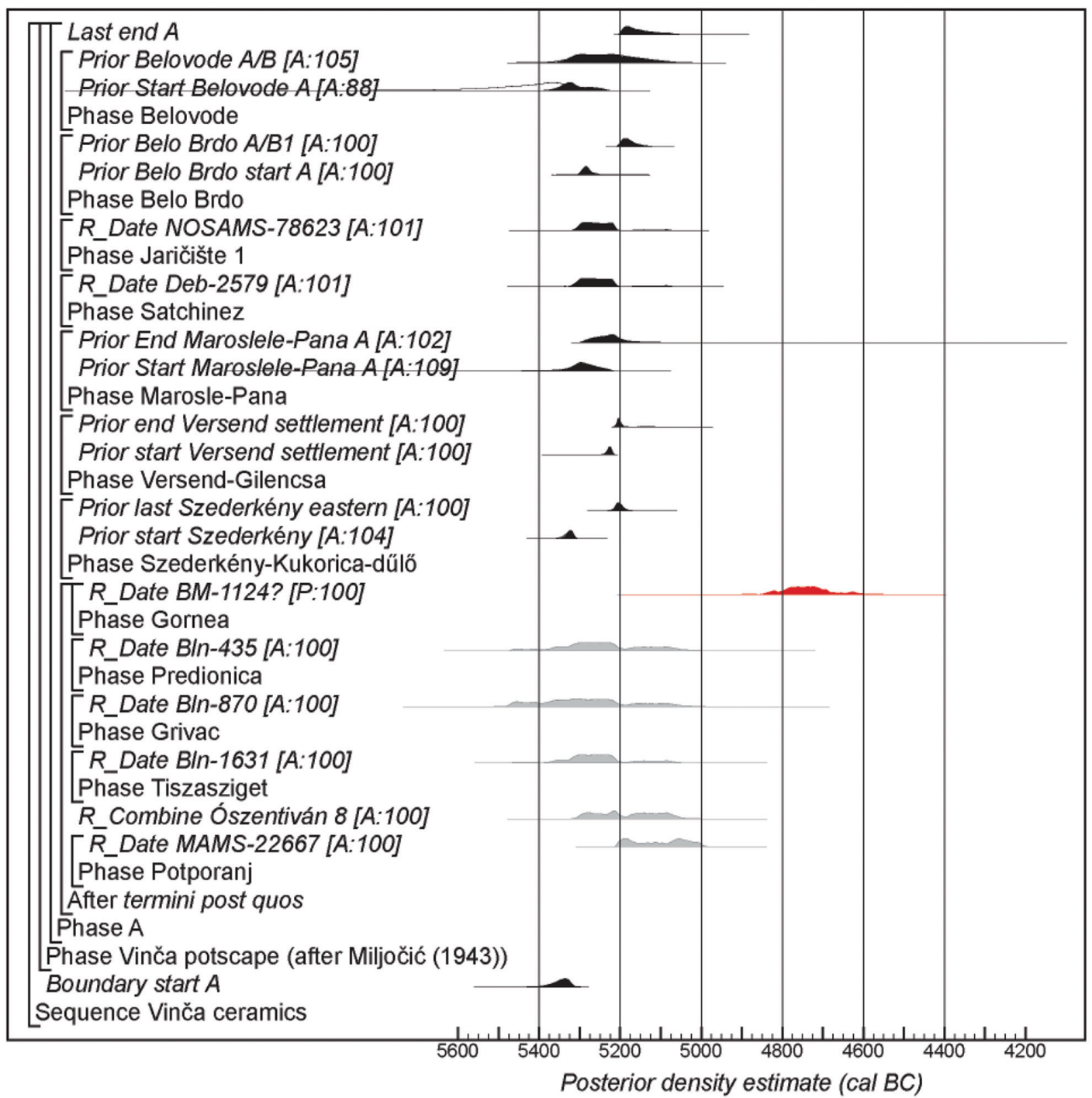

Fig. 25. Probability distributions of dates associated with Milojčić Vinča A ceramics (key parameters for individual sites have been imported from the models defined or cited in Figs. 4-23). The format is identical to that of Figure 7 (grey tone indicates the sample has a possible old-wood offset; red indicates a distribution excluded from the model). The model is defined exactly by the OxCal keywords and structure provided as supplementary information (Vinca_Milojcic_Model_1.oxcal).

the time when the LBK spread beyond the inital locus of its development in Transdanubia. Whatever the dating of its formative phase, all these models agree in placing this rapid expansion in the middle decades of the $54^{\text {th }}$ century cal BC (Fig. 41). This is precisely the time when the first Vinča pottery was made. The potential implications of this are explored in the Discussion below.

The component of the model relating to the currency of Vinča B1 ceramics is shown in Fig. 27. It suggests that this ceramic phase begun in 5355-5195 cal BC (95\% probability; start B1; Fig. 27), probably in 5330-5245 cal BC (68\% probability). The use of Vinča B1 ceramics ended in 5045-4800 cal BC (95\% probability; end B1; Fig. 27), probably in
5040-4915 cal BC (68\% probability). Vinča B1 ceramics were thus in use for a period of 185-505 years (95\% probability; duration B1; Fig. 38), probably for 230-395 years (68\% probability).

There is considerable uncertainty around the dating of Vinča B1 ceramics since, with the exception of Belo Brdo itself, all the sites are poorly dated. Such data as we have, however, are consistent with a relatively swift transition from Vinča $A$ at the beginning of the $52^{\text {nd }}$ century cal BC. There was a period of overlap (100\% probable), as is reflected in Lazarovici's $(1991.19-20,27)$ phase A3/B1. This period of overlap lasted for 25-245 years (95\% probability; $A / B 1$; Fig. 39), probably for $70-185$ years (68\% probability). 


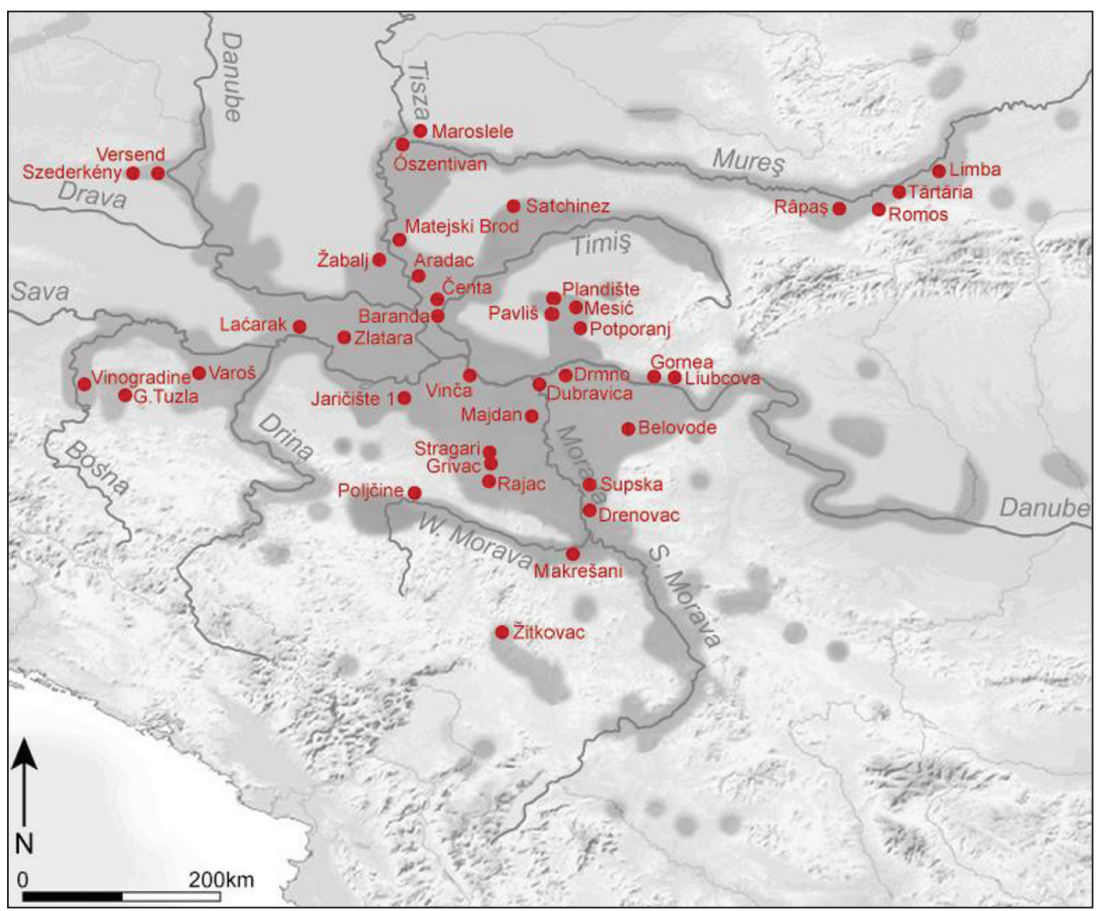

Fig. 26. Map showing distribution of sites from which Milojčić Vinča A ceramics have been recorded (greytone is approximately the maximum spatial extent of Vinča ceramics of all phases). For sites with radiocarbon dates see references in the text; for other sites see Marinković 1995; 2006; Vilotijević 1965; Stalio 1970; Jovanović 1965; Tasić 1958; 1965; Benac 1988; Leković 1995; Rašajski 1962; Jacanović 1988; Suciu 2009; Joanović, Prikić 1978; Jacanović, Đorđević 1990; Katunar 1988; Perić 2006; Garašanin, Garašanin 1979; Bogdanović 1988a; Nikitović 1995; and Stanković 1988; 1989. Râpaş is unpublished (A. Bărbat, pers. comm.)*.
There is a marked increase in the density of sites producing Vinča B1 ceramics (Fig. 28) in comparison to sites producing Vinča A ceramics (Fig. 26). It appears, however, that Vinča ceramics are no longer found upstream of the Danube confluence with the Tisza, although their continuing influence can be traced in the development of Sopot-type pottery. Sites with Vinča pottery are still found along the Timiş and Mureș valleys.

The component of the model relating to the currency of Vinča B2 ceramics is shown in Fig. 29. It suggests that this ceramic phase began in 5295-5105 cal BC (95\% probability; start B2; Fig. 29), probably in 5285-5270 cal BC (3\% probability), or in 5230-5130 cal BC (65\% probability). The use of Vinča B2 ceramics ended in 4920-4770 cal BC $(95 \%$ probability; end B2; Fig. 29), probably in 4905-4830 cal BC (68\% probability). Vinča B2 ceramics were thus in use for a period of 220-470 years (95\% probability; duration B2; Fig. 38), probably for 270405 years (68\% probability).

Again there was clearly a period of overlap (100\% probable) between Vinča B1 and Vinča B2 pottery.
This period of overlap lasted for $90-425$ years (95\% probability; B1/B2; Fig. 39), probably for 130-310 years $(68 \%$ probability).

The number of sites producing Vinča B2 pottery is greater than those producing Vinča B1 pottery, and its distribution extends further to the west and southeast. Sites in the lower Tisza valley, however, appear no longer to have access to Vinča pottery (Fig. 30), perhaps because the Szahálhát network was expanding from the north at this time ${ }^{16}$. The spatial distribution of the network appears to have reached its greatest extent in this phase (possibly in the later part of it, equivalent to Schier (1995) phase C1), spreading from Kalošević in the far west as far as Anzabegovo to the south-east and Ocna Sibilui to the north-east.

The component of the model relating to the currency of Vinča pottery which can only be assigned to Milojčić phases B1 or B2 is shown in Figure 31. It suggests that this combined phase began in 5360 5235 cal BC (95\% probability; start B; Fig. 31), probably in $5335-5275$ cal BC (68\% probability). This is entirely compatible with the estimated date for the

* We are aware of a number of sites in Bulgaria (e.g., Bulgarchevo) containing ceramic types which form part of the Vinča repertoire. They also occur, however, more widely in the area to the east of the Vinča network and so cannot be considered to be exclusively diagnostic Vinča forms. This contrasts with sites (e.g., Satchinez) which contain diagnostic Vinča pottery in contexts mixed with other clearly non-Vinča forms.

16 The Szakálhát culture evolves during Vinča B1 along the middle Tisza area. At the time of Vinča B2 Szakálhát and the closely related Bucovăt group dominate south-east Hungary and the western part of the Romanian Banat, extending well into the Serbian Vojvodina (Goldman 1985.64-66; Horváth 1983.90; Goldman, Goldman-Szenaszky 1991.194). 


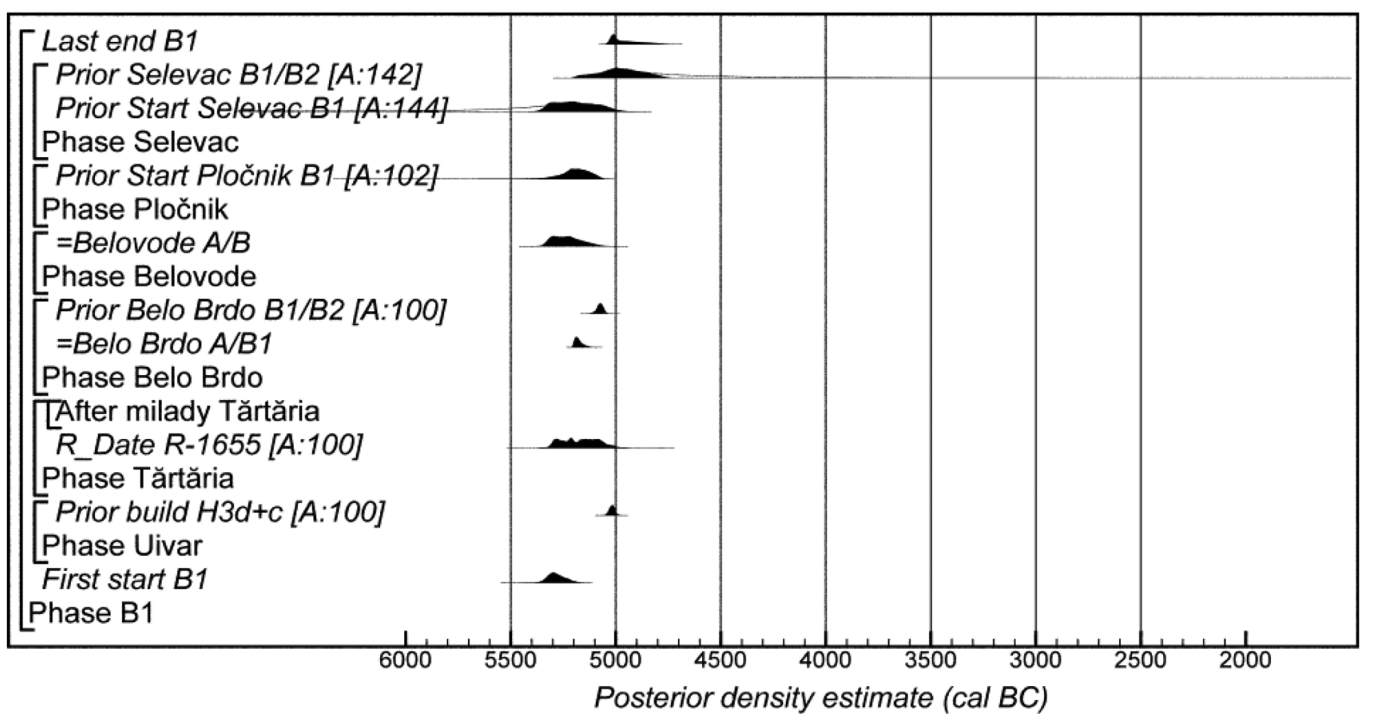

Fig. 27. Probability distributions of dates associated with Milojčić Vinča B1 ceramics (key parameters for individual sites have been imported from the models defined or cited in Figs. 4-23). The format is identical to that of Figure 7. The model is defined exactly by the OxCal keywords and structure provided as supplementary information (Vinca_Milojcic_Model_1.oxcal).

start of Milojčić phase B1 presented above (Fig. 27). This combined phase ended in 5070-4770 cal BC (95\% probability; end B; Fig. 31), probably in 50104825 cal BC (68\% probability). This posterior date estimate is entirely compatible with the estimated date for the end of Milojčić phase B2 presented above (Fig. 29), but is considerably less precise.

The component of the model relating to the currency of Vinča $\mathrm{C}$ ceramics is shown in Fig. 32. One distribution has been excluded from the model. This is the transition from Vinča $\mathrm{C}$ to Vinča D pottery at Petnica, which is 150 years earlier than the same transition from anywhere else. This seems implausible, since Petnica is a small occupation site which is not even on one of the major rivers that clearly provided the connectivity of the network; moreover, the stratigraphy of this site is not unproblematic (Orton 2012.16-20). Three distributions (shown in blue) for assemblages that can only be classified as either Vinča $\mathrm{C}$ or Vinča D are included as termini ante quos for the start of Vinča C. The model suggests that Vinča C began in 5115-4895 cal BC (95\% probability; start C; Fig. 32), probably in 5020-4905 cal BC (68\% probability). The use of Vinča $C$ ceramics ended in 4620-4400 cal BC (95\% probability; end C; Fig. 32), probably in 4550-4445 cal BC (68\% probability). Vinča $\mathrm{C}$ ceramics were thus in use for a period of 325-650 years (95\% probability; duration C; Fig. 38), probably for 390-555 years (68\% probability). Only the imprecisely dated sites at Belovode, Selevac and Gornja Tuzla suggest that Vinča $\mathrm{C}$ ceramics may have continued in use after $4700 \mathrm{cal} \mathrm{BC}$.
The distribution of sites producing Vinča $C$ pottery (Fig. 33) is very similar to that of sites producing Vinča B2 pottery (Fig. 30). Vinča ceramics are still absent from sites in the lower reaches of the Tisza valley but appear to occur on more sites in the Timiş valley.

Where we have been able to date the transition from Vinča B2 to Vinča C ceramics directly, the date estimates fall in a tight group in the generations around $4900 \mathrm{cal}$ BC (Fig. 34). There was clearly an overlap between these two ceramic phases $(100 \%$ probable). This period of overlap lasted for 20-260 years (95\% probability; B2/C; Fig. 39), probably for 50-180 years (68\% probability).

The component of the model relating to the currency of Vinča D ceramics is shown in Figure 35. It suggests that this ceramic phase began in 4870-4725 cal BC (95\% probability; start D; Fig. 35), probably in $4810-4740$ cal BC (68\% probability). The use of Vinča D ceramics ended in $4515-4360$ cal BC $(95 \%$ probability; end D; Fig. 35), probably in 4490-4415 cal BC (68\% probability). Vinča D ceramics were thus in use for a period of $250-455$ years $(95 \%$ probability; duration D; Fig. 38), probably for 285-390 years (68\% probability).

The distribution of sites with Vinča D ceramics is clearly concentrated to the south of the Danube with only a few sites in the southern Banat appearing on the north bank (Fig. 36). No pure Vinča D assemblages occur in Transylvania but it seems that the 
distribution of this type of pottery reaches the Sofia basin to the east.

Vinča D ceramics began after Vinča C pottery had first appeared, and endured for longer (100\% probable) (Fig. 37). Vinča C ceramics may have been in use for most of the currency of Vinča D types, if the late dating of Vinča $\mathrm{C}$ at Belovode, Selevac and Gornja Tuzla is robust (Fig. 32). The majority of dated sites came to an end in the 46th or the earlier part of the $45^{\text {th }}$ century cal BC (Fig. 35).

A summary of the dating of the phases of Vinča pottery suggested by Milojčić (1943) is shown in Figure 37 . Vinča pottery was clearly in use across a wide area from the mid- $54^{\text {th }}$ century cal $\mathrm{BC}$ to the mid$45^{\text {th }}$ century cal BC.

Each of these phases endured for several centuries, Vinča $\mathrm{A}$ being the briefest and Vinča $\mathrm{C}$ being the longest (Fig. 38). Successive phases routinely overlapped by a century or two (Fig. 39), but phases C and D overlapped by around 300 years. Either the connectivity of the network was loosening in the later centuries of its existence and there was more diversity in contemporary pottery forms, or our dating of the latest sites with Vinča $C$ ceramics (in particular Belovode, Gornja Tuzla and Selevac) is anomalous. The implications of this are discussed further below.

\section{Sensitivity analyses}

We further explore the robustness of the results from Model 1 by constructing an alternative model which treats the five Milojcić phases as sequential and abutting ( $c f$. Fig. 2). This means, for example, that there is no ending to phase $\mathrm{A}$ and no beginning to phase $\mathrm{B} 1$ but rather an abrupt transition from $\mathrm{A}$ to B1. The overall form of this model is illustrated in Fig. 40. The components of the model are similar to those illustrated in Figs. 25, 27, 29, 31-2 and 35 but where we have formal estimates for the dates of transitions at particular sites these have been combined in the model. The model is defined exactly by the CQL2 keywords and structure provided as supplementary information (Vinca_Milojcic_Model_2. oxcal).

We must make clear from the outset that this alternative model, Model 2, has poor overall agreement between the radiocarbon dates and the strict sequence of non-overlapping abutting phases (Amodel: 4; Fig. 40). This means that it is statistically implausible. Where the radiocarbon dates contradict the typological sequence is, however, enlightening and helps us to interpret the results of the preferred model.

All the data in Milojčić Phases A and B1 have good agreement with a strict sequence between them, and the two sites where we have been able to formally

Fig. 28. Map showing distribution of sites from which Milojčić Vinča B1 ceramics have been recorded (greytone is approximately the maximum spatial extent of Vinča ceramics of all phases). For sites with radiocarbon dates see references in the text; for other sites see Banner 1960; Grbić 1950; Draşovean 1996; Suciu 2009; Gligor 2009; Lazarovici 1979; Marinković 1995; 2006; Babović 1992; Stalio 1970; Joanović, Prikić 1978; Joanovič 1992; Jovanović 1965; Benac 1988; Marijanović 1988a; Mrkobrad 1982; Babović 1986; Jacanović, Đorđević 1990; Jacanović 1988; Trbuhović, Vasiljević 1970; Garašanin, Garašanin 1955; 1958; 1979; Perić 2006; Nikitović

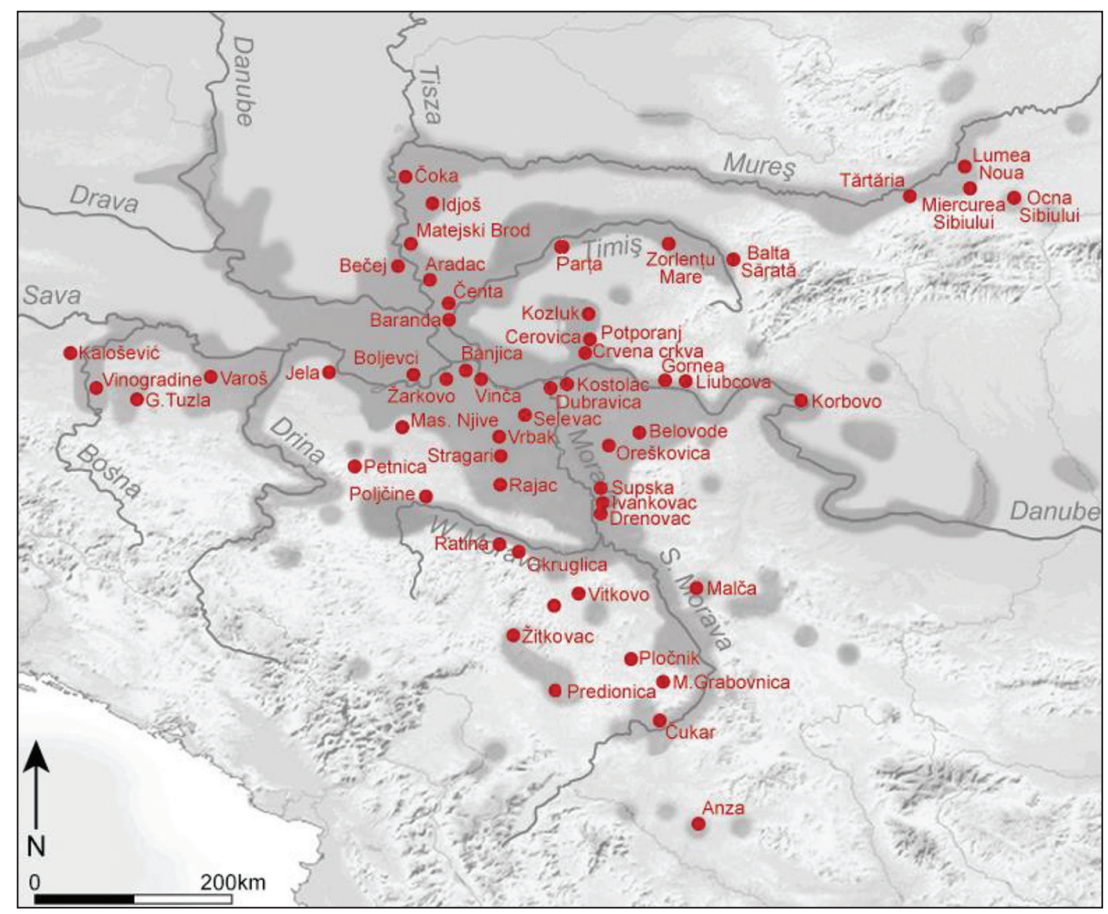
1995; Bogdanović 1983; 1988a; Stanković 1989; Madas 1970; Valović 1983; 1987; Tasić 1958; Krstić 1959; Tomić, Vukadin 1969; Garašanin, Ivanović 1958. 


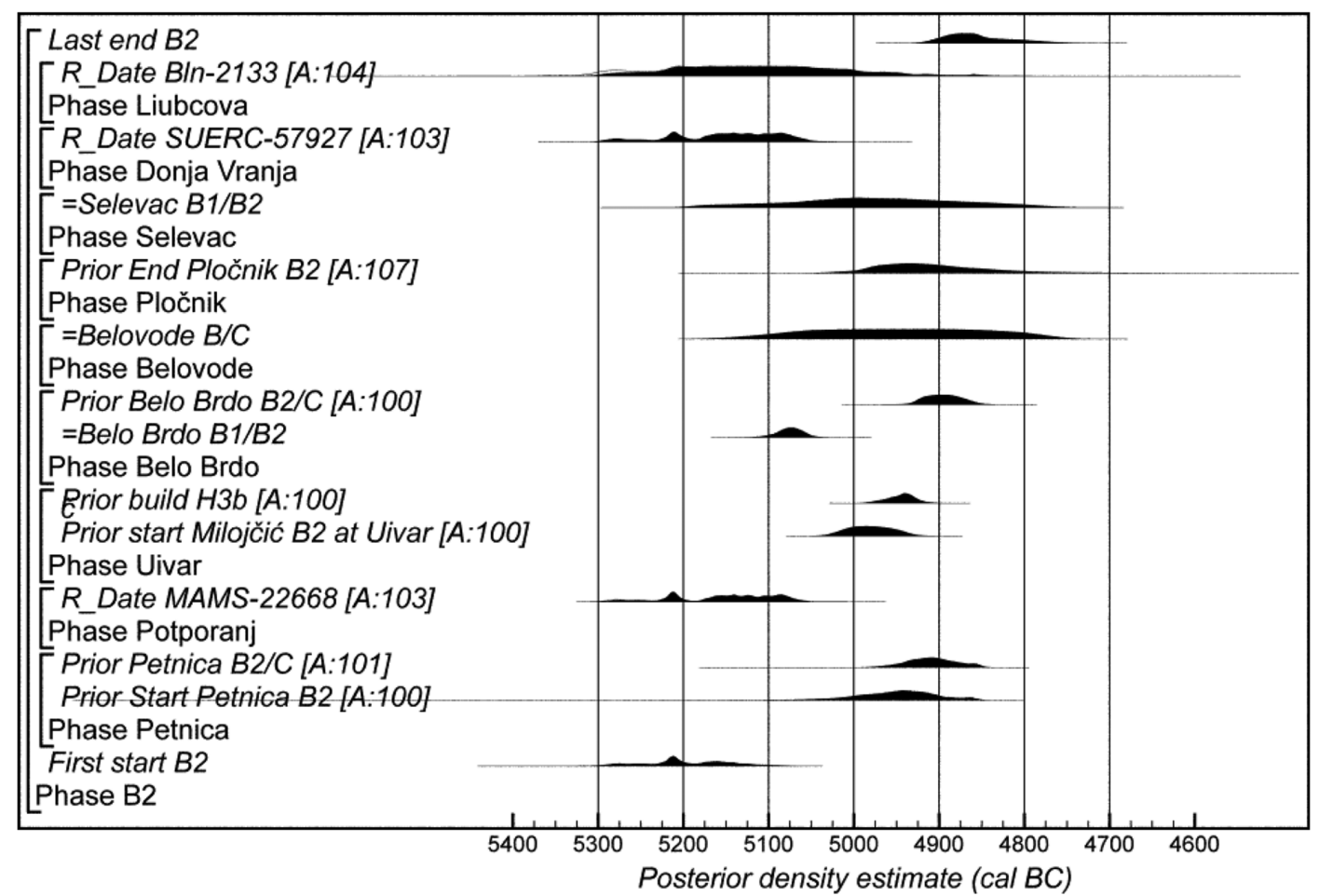

Fig. 29. Probability distributions of dates associated with Milojčić Vinča B2 ceramics (key parameters for individual sites have been imported from the models defined or cited in Figs. 4-23). The format is identical to that of Figure 7. The model is defined exactly by the OxCal keywords and structure provided as supplementary information (Vinca_Milojcic_Model_1.oxcal).

model the A/B1 boundary (at Belovode and Belo Brdo) have produced compatible date estimates for this transition $(A c o m b=108, A n=50, n=2)$. It seems likely therefore that the transition from Vinča A to B1 occurs relatively swiftly within the first decades of the $52^{\text {nd }}$ century cal BC.

Three distributions have poor agreement with a strict sequence between Milojčić phases B1 and B2. $M A M S-22668$, an animal bone from Potporanj (A: 13), and SUERC-57927, an animal bone from a pit at Donje Vranje (A: 21), are both rather earlier than would be expected if the strict succession of Vinča $\mathrm{B} 1$ and $\mathrm{B} 2$ is valid everywhere. In Vinča B1, build $H 3 d+c$ from Uivar is rather later than would be expected, on the same basis, for an assemblage of Vinča B1 ceramics. We note, however, that this Uivar assemblage is thought to be an imitation by local potters of Vinča B1 types, and so the archetype of the imitation may not have been new when copied. A variant of Model 2, which excludes build $\mathrm{H} 3 d+c$ from Uivar, brings the dates from Potporanj and Donje Vranje into good agreement with the sequence
(A: 87 and A: 88, respectively). The two sites where we have calculated the transition from B1 to B2 directly (Belo Brdo and Selevac) have produced date estimates that are compatible $(\mathrm{Acomb}=106, \mathrm{An}=$ $50, \mathrm{n}=2$ ). On this basis, it again seems likely that the transition from Vinča B1 to B2 was relatively swift, in the decades around or just after $5100 \mathrm{cal}$ BC 17.

All the data from Milojčić phases B2 and C are compatible with a strict sequence between them, and the three sites where we have been able to formally model the B2/C transition (Petnica, Belo Brdo and Belovode) have produced date estimates that are also compatible (Acomb $=123, \mathrm{An}=41, \mathrm{n}=3)$. Model 2 therefore agrees with our inference from Model 1 (see Fig. 34) that this transition occurred swiftly in the decades around or slightly before 4900 cal BC. The data from Vinča C, however, are not compatible with a strict sequence to Vinča D. Posterior distributions for the end of Vinča $C$ from Belovode (A: 56), Selevac (A: 2) and Gornja Tuzla (A: 0 and A: 47) are all later than would be expeted

17 Early dates from Masinske Nijve and Oreškovica may perhaps impart caution as to the speed of this transition, since the posterior density estimates for the start of both sites, currently assigned only generally to Vinča B, have poor agreement (A: 10 and A: 40, respectively) with the strict succession from Vinča A to B. 
Fig. 30. Map showing distribution of sites from which Milojéić Vinča B2 ceramics have been recorded (greytone is approximately the maximum spatial extent of Vinča ceramics of all phases). For sites with radiocarbon dates see references in the text; for other sites see Gligor 2009; G. Lazarovici 1979; Tasić 1961; Marijanović 1988a; Jacanović 1988; Madas, Brmbolić 1986; Jacanović, Šljivar 1995; Benac 1988; Marinković 1995; Tasić, Tomić 1969; Babović 1986; Jacanović, Đorđević 1990; Borović-Dimić 1995; Garašanin, Garašanin 1958; 1979; Perić 2006; Nikitović 1995; Bogdanović 1988a; Stanković 1989; Madas 1970; Valović 1983; 1987; Tasić

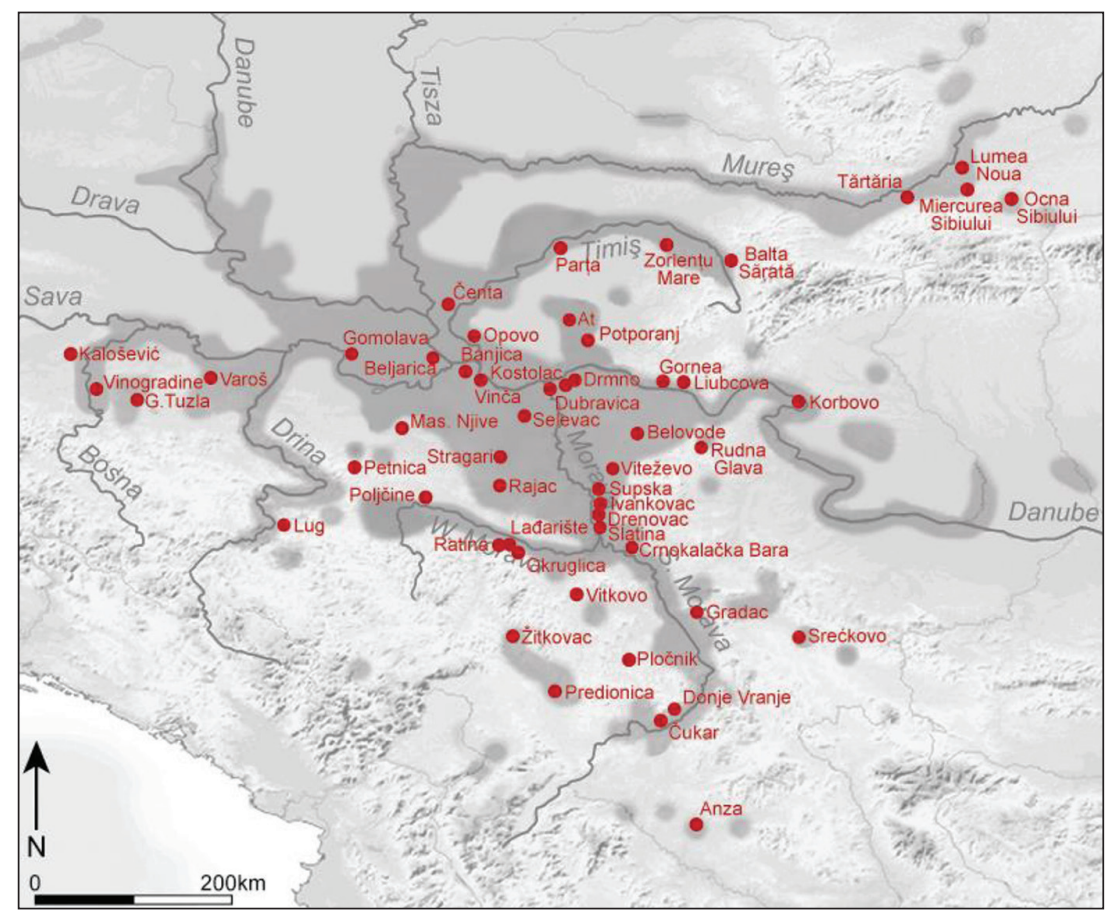
1958; Tomić, Vukadin 1969; Marić, Marić-Mirković 2011.

if Vinča C ceramics ceased to circulate at the time when Vinča D ceramics were first introduced. Of the three sites where we have formally modelled the $\mathrm{C} /$ D transition (Gomolava, Belo Brdo and Divostin 18), the date estimate for the transition at Gomolava is substantively earlier (by almost a century; A: 2) than the other two posterior distributions (Acomb $=76$, An $=41, n=3$ ).

It is not impossible that there was actually a swift transition from Vinča $C$ to Vinča $D$ in the first decades of the $47^{\text {th }}$ century cal BC. The dates from Selevac and Gornja Tuzla were on conventional bulk samples of charred plant material that could have contained an element of intrusive, later material, although the date estimate from Gomolava appears to be robust, since it rests on no fewer than ten results on samples of animal bone (Fig. 12). If the earliest sample associated with Vinča D at Gomolava, OxA-14710, a bone tool, however, was residual, then the estimated date of the transition here would shift more in line with those from Belo Brdo and Divostin. On the whole, however, the cumulative weight of these strands of evidence may be sufficient to indicate that there was really a considerable overlap between the use of Vinča $C$ and Vinča D ceramics. This has implications for the connectivity of the cultural network in the final centuries of its existence.
In conclusion, this sensitivity analysis suggests that, within the precision obtainable by the data that are currently available, the chest-of-drawers model of sequential ceramic phases is not importantly wrong, except perhaps in relation to the transition between Vinča $C$ and Vinča $D$, where a significant period of concurrent use seems probable.

\section{Discussion}

Over 45 years later, the claim of Colin Renfrew (1970.53) that analysis of the development of the Vinča culture 'represents one of the most challenging tasks in European prehistory' remains valid. In our introduction, we outlined many aspects of the Vinča culture, but here we are going to concentrate, first, on beginnings or origins, and secondly, on the character of the developed stages of the phenomenon. What insights do the better timings provided by formally modelled estimates provide?

We need, first, to set out briefly the interpretive frame within which better timings can be interrogated. As one of us has recently sketched (Boric 2015. 159-162), three main approaches to the study of the Vinča culture can be identified in past research: culture-historical, processual and post-processual. Each of these has given rather different answers to the related questions of beginnings and the nature

18 We have already excluded the estimate for this transition at Petnica as anomalous: see above. 


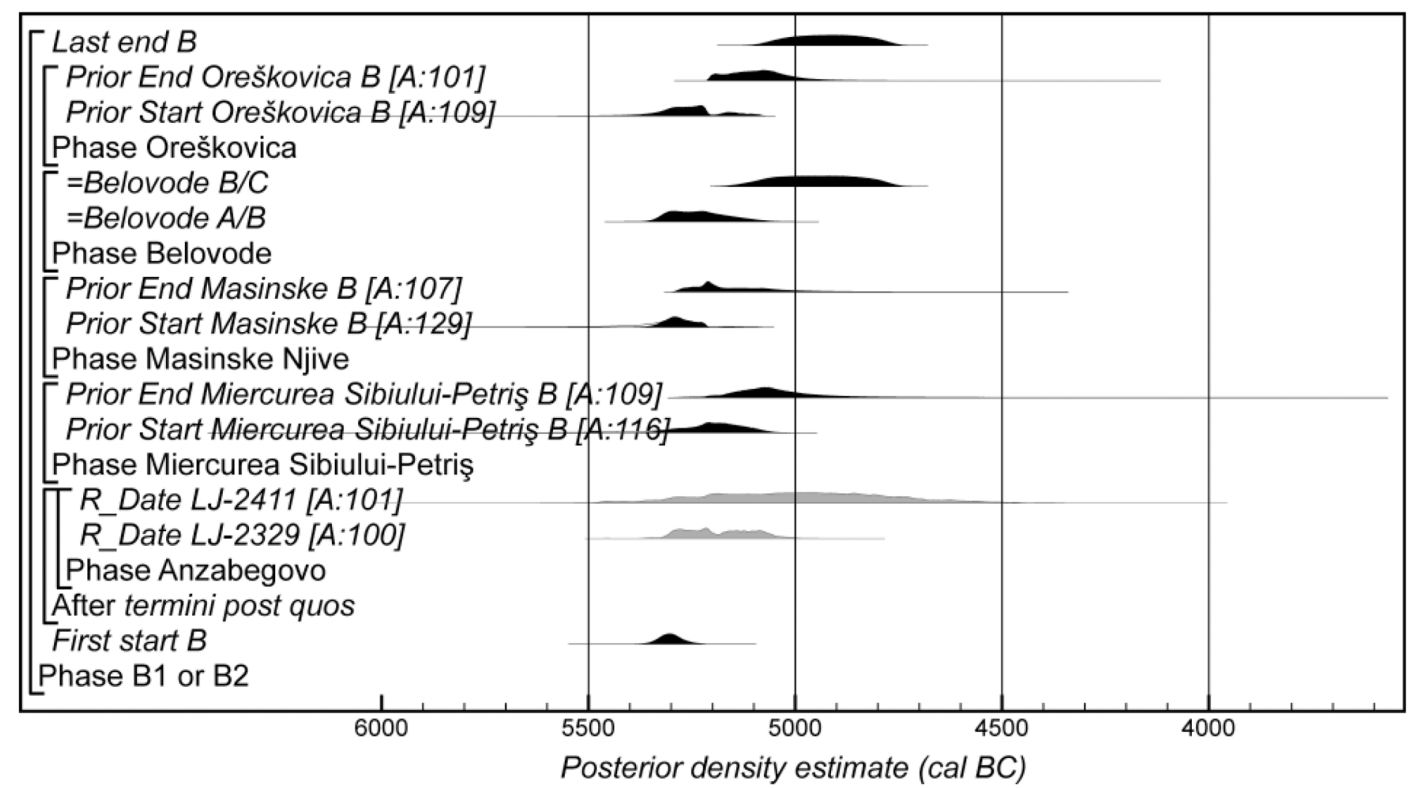

Fig. 31. Probability distributions of dates associated with Milojčić Vinča B1 or B2 ceramics (key parameters for individual sites have been imported from the models defined or cited in Figs. 4-23). The format is identical to that of Figure 7 (grey tone indicates the sample has a possible old-wood offset). The model is defined exactly by the OxCal keywords and structure provided as supplementary information (Vinca_Milojcic_Model_1.oxcal).

of subsequent development. The culture-historical approach has been dominant among researchers in the region, though not universally so (see, for example, Korošec 1965). Out of the total range of Vinča material culture, this approach has placed heavy reliance on pottery typology (charted by Chapman 1981.Ch. 4). For origins, it sees disjuncture in longerterm sequences, and derives fresh beginnings from the outside, on a large scale and potentially from long distances: in some accounts from as far afield as Anatolia (Efe 2000; Garašanin 2000). There was little further explicit reflection on the character and conditions of different kinds of population displacement and colonisation. Subsequent developments were largely left to take care of themselves, except in those variants which saw another wave of arrivals of southern origin: the so-called Vinča C 'shock' already noted above. The approach did, however, create coherent (though often varying) narratives about the broad history of a perceived social entity.

The processual approach to the Vinča culture was characteristically concerned with the playing out of local or regional conditions. In the quotation above, Colin Renfrew (1970.53) elaborated that the Vinča culture 'developed in these areas through the operation of local factors, and must be explained in terms of these factors', though he certainly took seriously the previous claims for outside involvement. In terms of origins, continuity was sought, though on then imprecisely defined timescales, especially in material sequences, including those of pottery, and in landscape use (Chapman 1981.5, Ch. 4). Consistent with this kind of focus, the concept of the autonomous household was proposed as a major agent of change in the processual narrative of the development and eventual break-up of the Vinča culture (Tringham, Krstic 1990b.581). Broad trends rather than precise chronology were the temporal currency. Post-processual approaches have focused on selected situations. An important sketch of the development of Vinča-Belo Brdo itself was offered, with careful consideration given to the character and sources of material in use at the tell; the resulting account asserting the early dominance and eventual slow decline of the site implies a wider narrative, but does not explicitly document it (Chapman 2000.203-220). Other themes, broadly classifiable as post-processual, have included the nature of deposition and symbolic dimensions of houses (Boric 2008; 2015.162; Tripković 2007; 2013; Crnobrnja et al. 2009; Spasić, Živanović 2015). Wider narratives of beginnings and subsequent development, however, have often been laid aside in this change of focus, and for the most part, chronological precision has not been a major concern of such contextual approaches.

Other interpretive approaches might be advocated. Culture evolutionary theory (as variously set out in, for example, Shennan 2009; Bentley et al. 2011) could be advocated (Boric 2015.189-191). The 


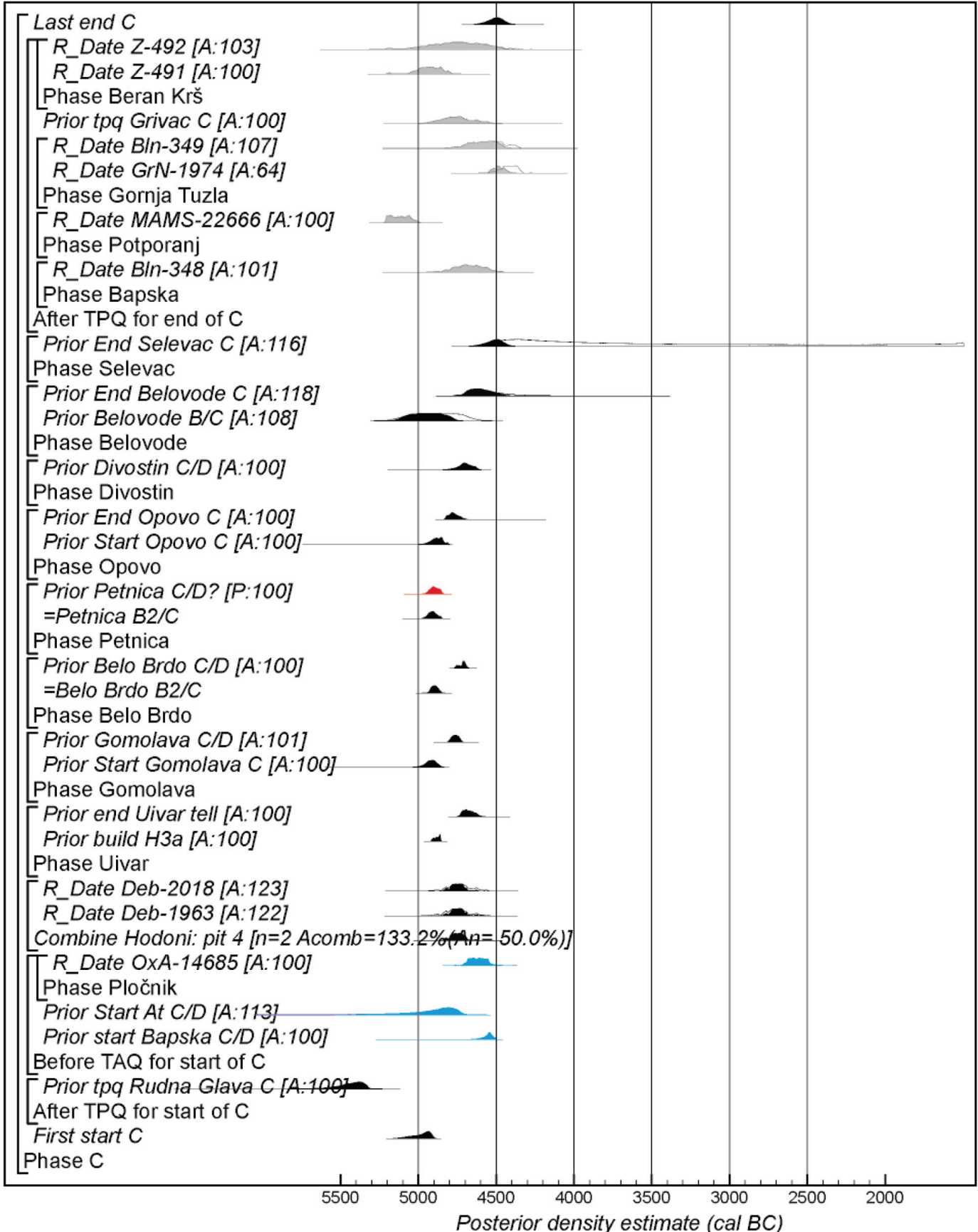

Fig. 32. Probability distributions of dates associated with Milojčić Vinča C ceramics (key parameters for individual sites have been imported from the models defined or cited in Figs. 4-23). The format is identical to that of Figure 7 (grey tone indicates that a sample has a possible old-wood offset; red indicates a distribution excluded from the model; blue indicates a distribution modelled as a terminus ante quem). The model is defined exactly by the OxCal keywords and structure provided as supplementary information (Vinca_Milojcic_Model_1.oxcal).

recent fashion of ascribing much greater agency to things - the ontological turn (among a host of others, see Olsen 2010; Hodder 2012; Rivzi 2015; see also Borić 2015.191-193) - could be extended to the rich material assemblages of the Vinča culture. Here, we choose not to follow either. The former tends to dehumanise complex processes of social interaction, and it is hard to escape the neo-Darwi- nian baggage that comes with it. The latter requires a much longer debate than we have space for here. It deliberately decentres human agency (see also Van Dyke 2015), much more precise narratives for which we are seeking to establish in this paper ( $c f$. Drassovean et al. submitted). If both approaches are for further discussion elsewhere, what we have found helpful are some of the terms and concepts 
Fig. 33. Map showing distribution of sites from which Milojčić Vinča C ceramics have been recorded (greytone is approximately the maximum spatial extent of Vinča ceramics of all phases). For sites with radiocarbon dates see references in the text; for other sites see Draşovean 1996; Gligor 2009; Jacanović 1988; Marijanovič 1988b; Benac 1988; Trbuhović, Vasiljević 1970; 1975; Brukner 1961; Tasić, Tomić 1969; Babović 1986; Jocić 1989; Borović-Dimić 1995; Garašanin, Garašanin 1958; 1979; Perić 2006; Nikitović 1987; 1995; Bogdanović 1988; Jurišić 1959; Krstić 1964; Anđelković-Despotović, Redžić 1991; Valović 1983; 1987; Marić, Marić-Mirković

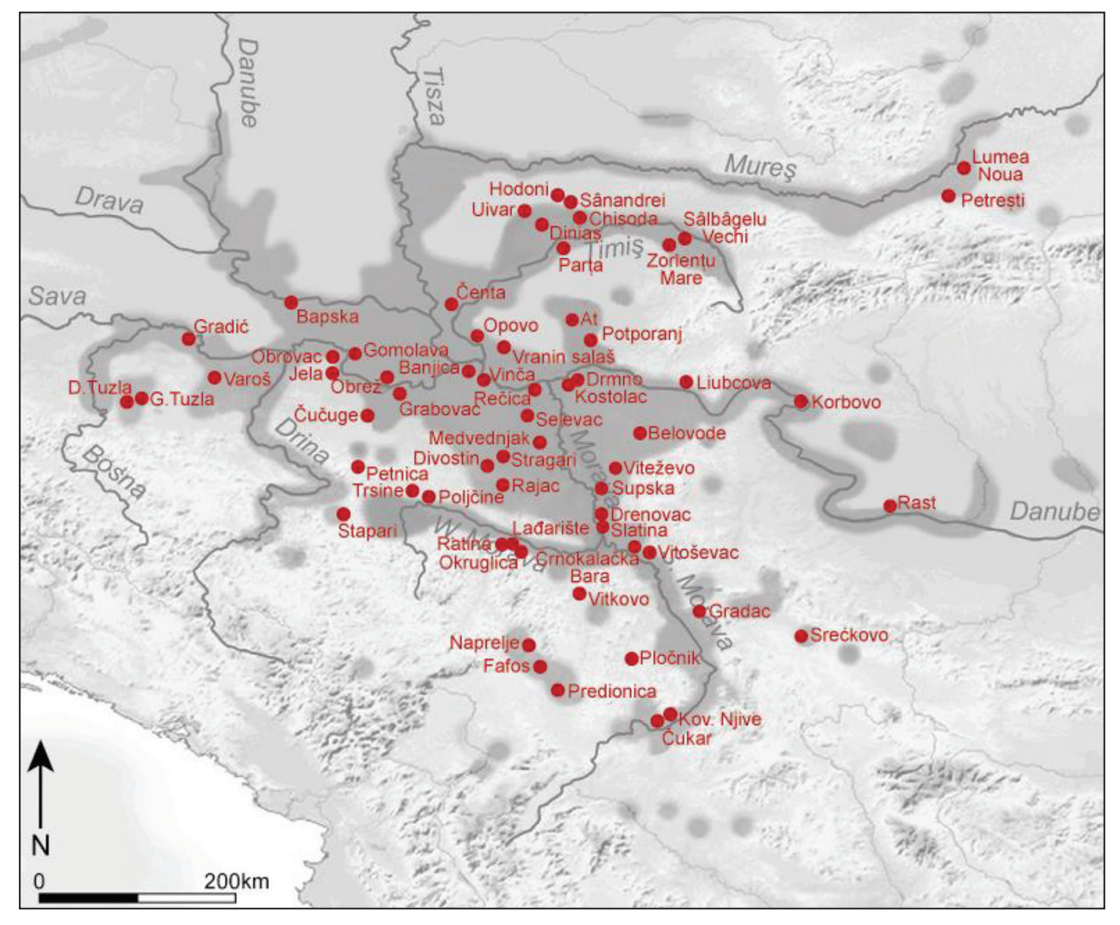
2011; Madas, Brmbolić 1986; Lazić et al. 1988; Todorović 1968; Bulatović 2003; Jacanović, Šljivar 1995; Tomić, Vukadin 1969; Stalio, Galović 1956; Vuković et al. 2016; Dumitrescu 1980. Petreşti is unpublished.

from ongoing debates on themes of hybridity and ethnogenesis, in the field of the archaeology of colonialism. As a proposition which is useful for us to reflect upon, Matthew Liebmann (2013.27) has asserted of the three primary means by which new things come into being, that invention ("the creation of wholly original objects, styles and technologies") is the rarest, that divergence (or evolution, by which "changes to an existing form through time result in the eventual creation of multiple separate types through splitting and branching") has been the focus of much archaeological attention, and that convergence, or "creation through recombination", is "probably the most common", though less studied in past research by archaeologists. In these terms, it seems clear that the culture-historical approach to the Vinča culture has favoured some version of invention for origins and kinds of divergence for subsequent development, while the processual approach has largely plumped for divergence; the possibility of convergence, in these terms, appears largely to have been neglected.

This is not the place to review in detail all the competing notions such as hybridity, acculturation, syncretism, bricolage, creolisation and mestizaje, or the advantages and disadvantages of their deployment (Liebmann 2013; 2015; Silliman 2015; and references), but it is useful to retain the sense of grounded detail which such studies offer. Matthew Lieb- mann (2015.331-334), for example, looks at the production of soup plates within the repertoire of Spanish-inspired Pueblo ceramics, over the specific timeframe of 1598-1700, noting an interplay of external and local factors in their design and decoration. Barbara Voss (2015.665-660) associates the wider notion of ethnogenesis with historical circumstances in which practices of identification are structurally transformed', often as the result of 'substantive demographic shifts - aggregation, disaggregation, displacement, and migration - combined with the emergence or imposition of new structures of power'. She stresses, however, that ethnicity has to be demonstrated rather than assumed (Voss 2015. 658 ), and questions the often lazy translation of archaeological culture into ethnic entity (Voss 2015. 660).

We therefore seek to interpret the timings of Vinča ceramics presented in this paper within an approach that might broadly be classified as contextual and practice-based. Our principal evidence is that of the pottery itself, and it is important to stress that the vast majority of Vinča ceramics have been found in settlement contexts, and especially in association with houses and dwelling horizons. There is a wealth of information about later Vinča houses. Well-preserved contexts such as houses at Crkvine-Stubline, part of a local network of sites of varying size, some $40 \mathrm{~km}$ south-west of Belgrade and Vinča-Belo Brdo 


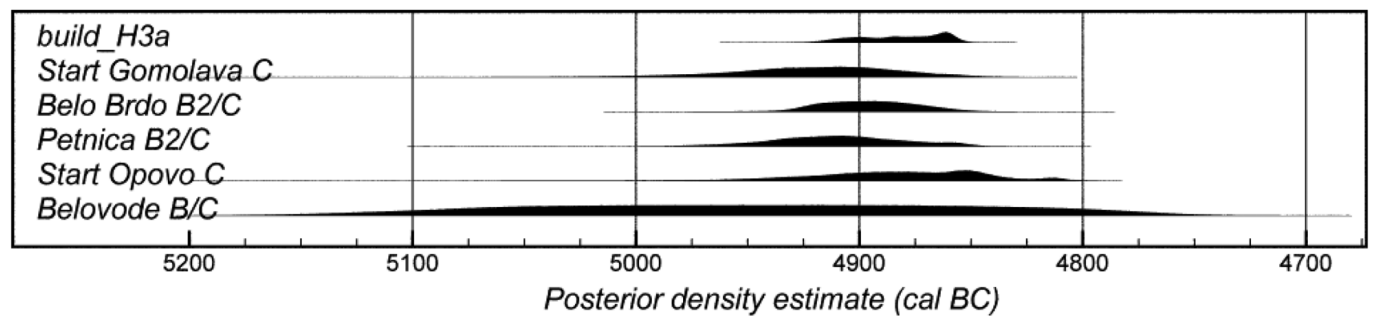

Fig. 34. Probability distributions of dates associated with the introduction of Vinča C ceramics, derived from Model 1.

(Crnobrnja et al. 2009; Crnobrnja 2012), had lots of pots in them: 'dozens of ceramic vessels' and 'a large number of storage vessels' in house $1 / 2008$ (Spasić, Živanović 2015.220). Some of these may have been stacked on wooden shelves (Crnobrnja et al. 2009.19). There are plentiful other examples, such as at Divostin (Tripković 2010). Occasionally pots are found in the spaces outside, in between houses (Nikolić, Vuković 2008). This household setting is therefore presumably the context in which Vinča pottery was principally used, for a wide range of tasks, from food preparation (though the direct evidence for that is surprisingly sparse), storage and consumption. It may be that vessels most open to public gaze, literally passable from hand to hand, such as certain types of bowls, were the ones most likely to change the fastest through time, as evidenced in the correspondence analyses of bowls from Vinča-Belo Brdo (Schier 1996; 2000); these might also have been the vessels most likely to break (David 1972). Some forms, such as protome vessels, seem to have remained more or less unchanged through the sequence (Spasic, Crnobrnja 2014). And it is important to remember that pottery was only one element of the total materiality of the house, and other constituents such as tables, hearths

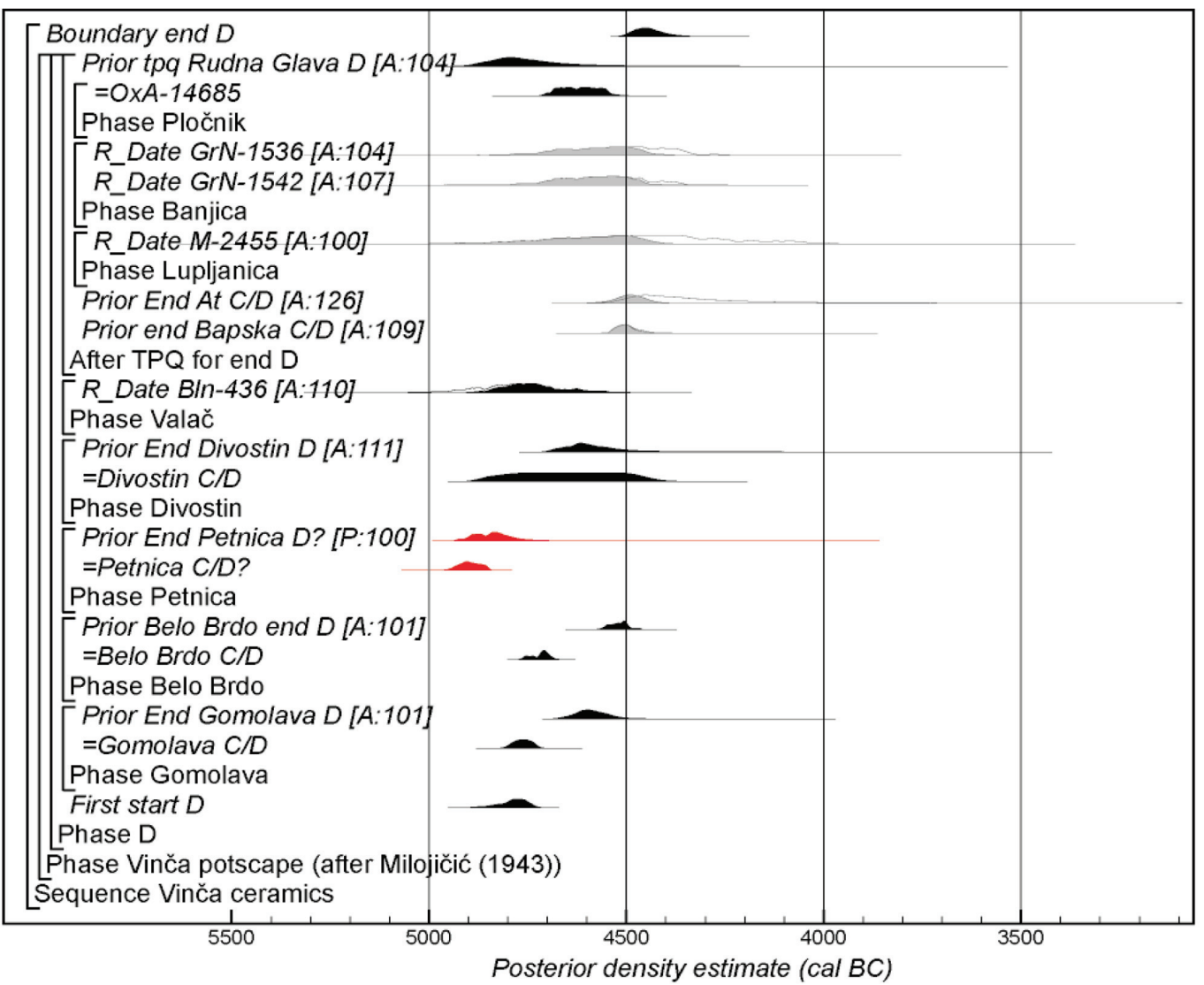

Fig. 35. Probability distributions of dates associated with Milojčić Vinča D ceramics (key parameters for individual sites have been imported from the models defined or cited in Figs. 4-23). The format is identical to that of Figure 7 (grey tone indicates that a sample has a possible old-wood offset; red indicates a distribution excluded from the model). The model is defined exactly by the OxCal keywords and structure provided as supplementary information (Vinca_Milojcic_Model_1.oxcal). 
Fig. 36. Map showing distribution of sites from which Milojčić Vinča D ceramics have been recorded (greytone is approximately the maximum spatial extent of Vinča ceramics of all phases). For sites with radiocarbon dates see references in the text; for other sites see Jacanović 1988; Vuković et al. 2016; Marijanović 1988b; Benac 1988; Crnobrnja et al. 2009; Marić 2010; Todorović 1966; Bogdanović 1988a; 1988b; Jocić 1989; BorovićDimić 1995; Garašanin, Garašanin 1979; Perić 2006; Jurišić 1960; Bogdanović 1988a; 1988b; Todorova 1990; Anđelković-Despotović, Redžić 1991; Valović 1983; 1987; Madas, Brmbolić 1986; Lazić et al. 1988; Jacanović, Šljivar 1995.

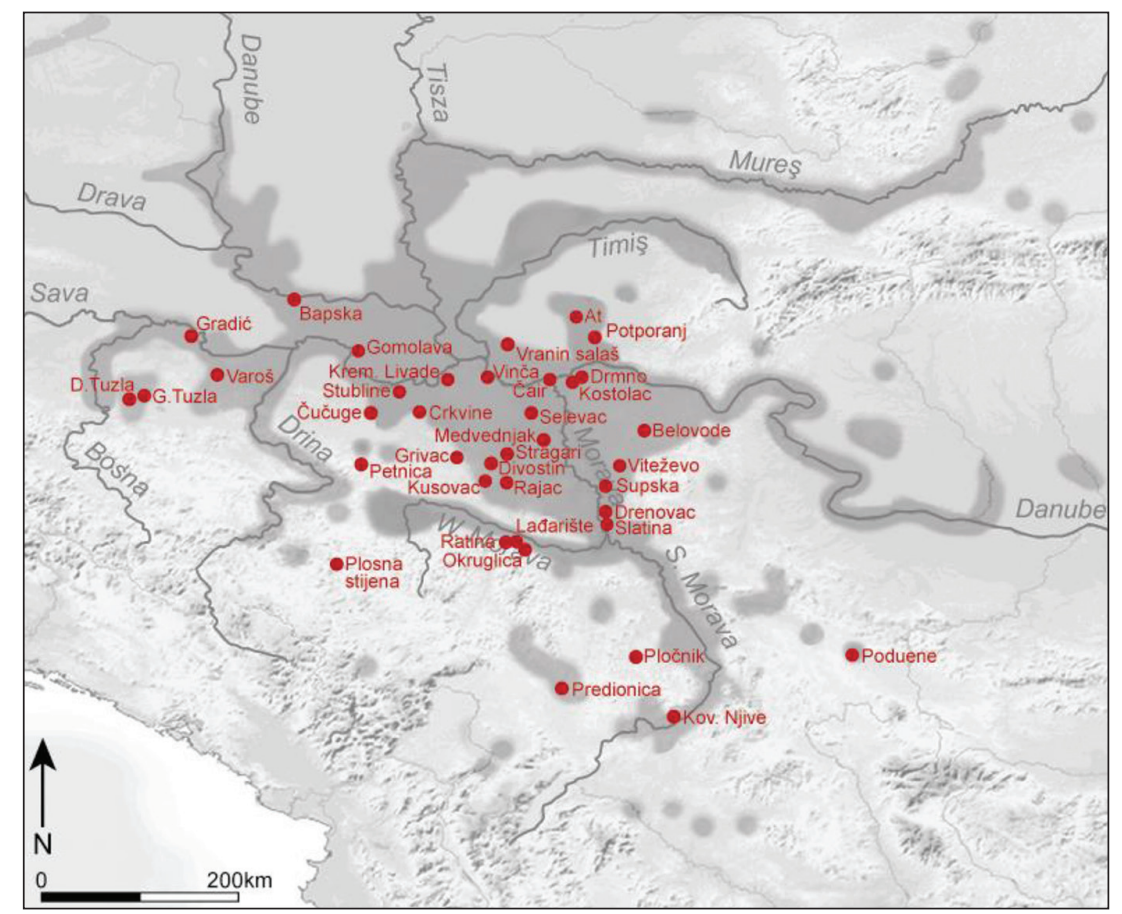

and storage facilities, which help to define a suite of eating practices (Spasić, Živanović 2015), and the layout of house interiors themselves, could have been at least as important as pottery in the creation and projection of social identities. So the context of pottery use was probably primarily associated with houses, but given the broad sharing of style seen in the wide distributions (Figs. 26, 28, 30, 33, and 36), on this basis alone it is extremely unlikely that households were autonomous; it is far more likely that groups of houses and neighbourhoods were the nodes through which intense connections were effected. On a note of caution, we have to recognise that our knowledge so far of early Vinča domestic contexts is much worse (though that helps to define a clear goal for future research). The detailed record for Vinča A contexts in Serbia, especially, is dire. By way of brief example, Trnovača has poorly defined wattle and daub structures (Jovanović 1965), while Stagari is reported to have similar structures, but these are not illustrated (Stankovic 1989). Likewise, while there is detailed information on the mix of ceramic styles associated with particular longhouses at Szederkény and Versend in south-west Hungary (Jakucs et al. 2016; submitted), the material comes from flanking pits, not house floors. This lacuna hampers what we can say about the conditions of the emergence of the Vinča ceramic style.

Another gap in knowledge concerns the making of pottery. Few if any structures have been identified as being associated with pottery production; the northern part of the interior of house 8 at Banjica has been suggested as a candidate (Tripković 2007. 74,119 ), but the evidence is ambiguous (Todorovic, Cermanović 1961). Importantly, we do not know whether all households made pottery, or if certain potters served communities at large. Whilst more data on chaînes opératoires and archaeometric analyses will help us refine our understanding of pottery production as a whole, they are of limited use to identify units and scales of production. Another avenue worth exploring would be the identification of differences in standardisation, as tentatively identified by Vuković (2011) between the sites of VinčaBelo Brdo and Motel Slatina, assuming that they reflect levels of craft specialisation. We further note a fragment of the perforated clay floor which separated the fire chamber from the pottery chamber in a two-chambered kiln that was recovered from a lower fill of enclosure ditch F1053 at Uivar. This find provides a terminus ante quem for the use of two-chambered kilns in the production of ceramics of 4855-4755 cal BC (95\% probability; dig F1053; Schier et al. forthcoming.Fig. 6.17), probably of 4830-4780 cal BC (68\% probability) - a time when Vinča B2 ceramics were current (Schier 2005).

In turning then to beginnings and development, it is obvious that we have gathered up a sample that represents currently available dated sites, with a range in both the quality and quantity of samples. 
Without doubt, a better dataset can be created in the future. We have also raised questions about the detail of the available typological schemes. Those can also be refined in the future. But we believe that the combination of more precise estimates of timings, order and duration, the distributions and density of known sites with diagnostic pottery through successive phases, and information about context, is sufficiently powerful to enable a preliminary reconsideration of important dimensions of the Vinča culture.

\section{Beginnings}

The modelled estimates for the appearance of Vinča A pottery given above suggest a rapid introduction. The earliest sites dated so far belong in the north of the distribution. The overall density of sites is not as great as in later phases. Simply in these terms, neither the spatial pattern nor the temporal distribution match what the formerly proposed bigscale migrations might be expected to have produced. Those earlier hypotheses were never accompanied by explicit consideration of either the conditions in the homeland of colonists or of the circumstances in which newcomers operated once arrived in fresh territory. That has, however, been set out elsewhere, and on a comparative (but not necessarily universal) basis, there often seems to be a process of initial scouting, followed by movement by selective groups, rather than wholesale populations (Anthony 1990; 1997). To take just one specific example, Susan Alt $(2006.290,294)$ set out three criteria for detecting possible migration into the American Bottom at the onset of the Mississippian phase - regional population growth, patterns of diversity and the distribution of non-local pottery types - but she also proposed a framework in which both migration and local development could be seen as components of the same process, involving convergence and hybridity.
Now it certainly seems to be the case that ceramic traits that overlap with the Vinča repertoire are found widely in the southern Balkans and northern Greece broadly in the same horizon as the appearance of Vinča ceramics. This refers to the widely distributed dark burnished wares that are variously represented among the ceramic assemblages of Karanovo III and the Late Neolithic or Tsangli phases of Bulgaria and northern Greece (Georgiev 1961; Lazarovici 1979.72-74; Efstratiou et al. 1998; Kotsakis 2014). But these dark wares are only part of much wider repertoires; there are many painted wares as well (Kotsakis 2014.61). To take just two examples, unusual circumstances of preservation in one context at Promachon-Topolnitsa on the GreekBulgarian border produced decorated bark, part of a wide range of pot forms and decorations (Koukouli-Chryssanthaki et al. 2007.Fig. 19), and there were some painted vessels among the mainly dark wares in phase II at Makri in Agean Thrace, informally estimated as dating after $5500 \mathrm{cal} \mathrm{BC} \mathrm{(Efstratiou} \mathrm{et}$ al. 1998.32). Informal estimates for the start of the northern Greek Late Neolithic are certainly compatible with the Vinča chronology set out above, but relatively few sites have so far been radiocarbon dated with rigour (see, for example, Dispilio: Facorellis et al. 2014), and there has been little Bayesian modelling so far of this horizon (Kostas Kotsakis, pers. comm.). It does seem to be the case that in these areas this horizon sees a marked increase in the number of sites and their much wider distribution across the landscape, compared with earlier settlement (Kotsakis 2014.60); the lakeside site of Dispilio (Karkanas et al. 2011) can usefully stand as a specific single example of this trend. So there is no need to disconnect processes in the southern Balkans and northern Greece from those operating further north, but it now appears a very clumsy explanation to derive all northern changes from the south.

Posterior density estimate (cal BC)

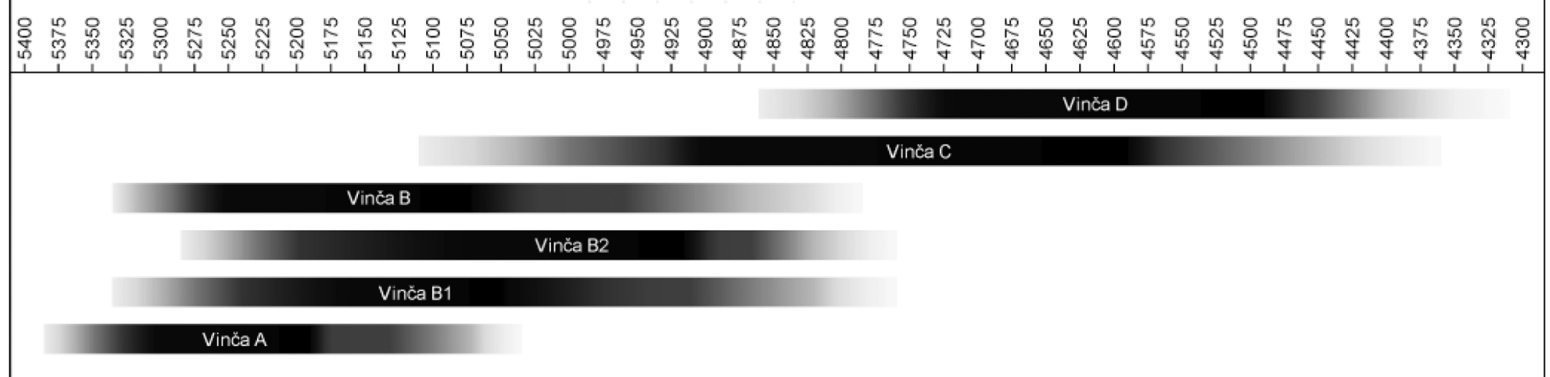

Fig. 37. Schematic diagram showing the currency of the different phases of Vinča ceramics proposed by Milojčić (1943) (the darker the shading the more probable that a ceramic phase was present in a particular 25-year period), derived from Model 1. 


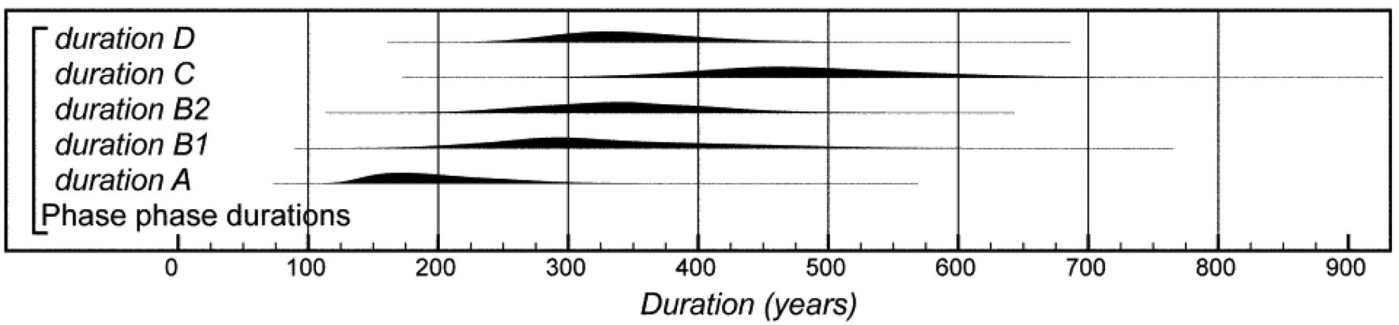

Fig. 38. Key parameters for the duration of the phases of Vinča ceramics proposed by Milojčić (1943), derived from Model 1.

The timing and distribution of Vinča A ceramics as set out above can be argued to better align with processual explanation of local or regional development. But things may not have been as simple as this, and that processual approach turns out, in our view, to have been far too myopic: too constrained within too narrow a spatial perspective. There is, first, still the question of how material culture developed from the Starčevo to the Vinča repertoire. Some elements of local continuity have already been noted (as proposed by Chapman 1981; Lekovic 1990); the Hungarian notion of 'proto-Vinča' elements (Makkay 1990) has long been debated. On their own, however, these seem insufficient, without a further assumption of rapid and extensive material changes. We know that there was a measurable gap in the occupation of Vinča-Belo Brdo itself between the Starčevo and Vinča phases (Tasić et al. 2016a; 2016b), but there is still much work to be done and beyond the remit of this paper - to date and model the timing and tempo of this transition (see also Porčić et al. 2016). What we can stress here is the apparent synchronicity of the appearance of Vinča ceramics and the earliest LBK diaspora, as set out above. Now, entirely indigenist explanations for the appearance of the LBK (e.g., Whittle 1996) have not stood the test of time, and the increasing weight of aDNA evidence (now bolstered by genomic analysis) supports a substantial, perhaps major, element of new population dispersing into central and western Europe (among others, see Brandt et al. 2013; D. Hofmann 2015; Szécsényi-Nagy et al. 2015; Olalde et al. 2015; Hofmanová et al. 2016; Lazaridis et al. 2016). On the evidence of Szederkény and Versend in southern Hungary (Jakucs et al. 2016; submitted), the $54^{\text {th }}$ and $53^{\text {rd }}$ centuries cal $\mathrm{BC}$ were also a time of considerable cultural and material fluidity, in circumstances that also involved people on the move. So it is probably better to see the transformations which led to the emergence of Vinča material repertoires and practices in this kind of wider perspective, and a degree of convergence, as well as divergence, should certainly be kept in mind. Given the aDNA evidence both from the periphery of the Vinča world (Hervella et al. 2015) and from the northern part of the Carpathian basin (Szécsényi-Nagy et al. 2015; Gamba et al. 2014) for further shifts in the patterns of haplotypes through the longer sequence from the sixth to the fifth millennia cal BC, it would be unwise to exclude entirely the possibility of some population movement from the south to the north, though that could also be derived from complex displacements and shifts within the northern part of the Carpathian basin. Further genomic analysis (cf. Hofmanová et al. 2016; Lazaridis et al. 2016) may help to clarify some of these issues in future research.

We suggest that in place of 'the old tired accounts of migration and diffusion' (Kotsakis 2014.65) a much more complex and challenging account needs now to be given of rapid and extensive change, that has to be seen at local, regional and inter-regional scales, which involved material transformations to suit the changing circumstances of increasing populations more widely distributed across their landscapes, and some of whom may have been caught up in processes of movement and displacement. Some strands in shifting material repertoires were very widely distributed, but those can probably best

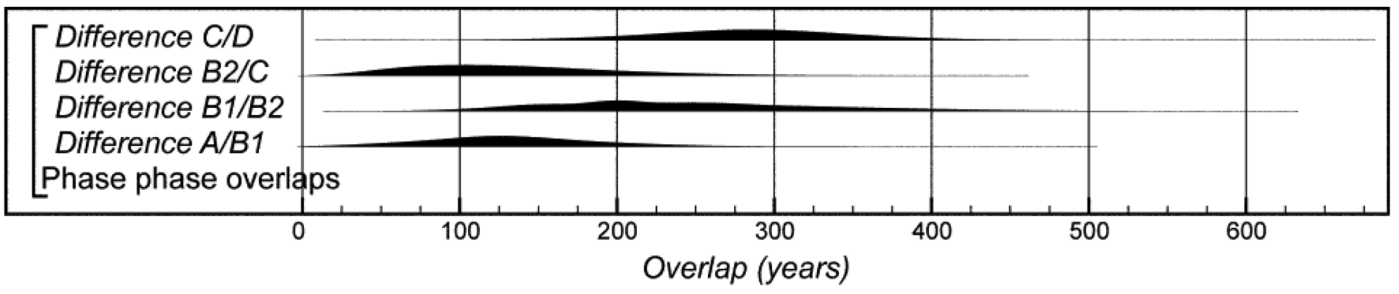

Fig. 39. Key parameters for the overlap between phases of Vinča ceramics proposed by Milojčić (1943), derived from Model 1. 


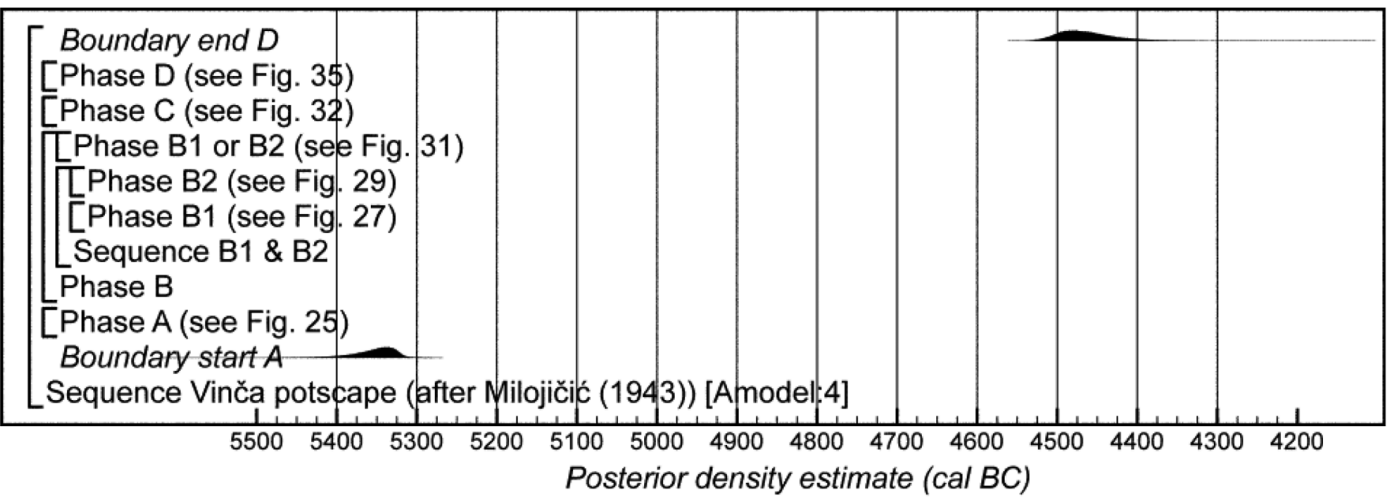

Fig. 40. Overall form of the chronological model for the phasing of Vinča pottery proposed by Milojčić (1943) (Model 2). The format is identical to that of Figure 7. Components of this model are illustrated in Figures 25, 27, 29, 31-32, and 35. The model is defined exactly by the OxCal keywords and structure provided as supplementary information (Vinca_Milojcic_Model_2.oxcal).

be further investigated as media through which social connections across this very broad, shifting world were expressed. As a discipline, we have been comfortable debating intensely the beginnings of the Neolithic, but we have been far less successful so far in thinking through subsequent transformations.

\section{Development}

Increasing connectivity seems to define the next phases of development, from Vinča B1 through Vinča D. though we have noted difficulties above in differentiating between $\mathrm{B} 1$ and $\mathrm{B} 2$ assemblages in some areas, it seems that the trend following the A phase was towards the appearance of more sites in the landscape. The greatest density is reached overall already by the Vinča B2 phase, and that is then maintained in the Vinča $C$ phase. On the ground, this coincides, as noted also above for northern Greece and the southern Balkans, with a spread in the distributions of sites across local landscapes (e.g., Chapman 1990), and with the appearance of more tells and larger flat sites. At this point, we can indeed perhaps best think in terms of local and regional factors at work. This appears to have been an intensifying but at the same time stable phenomenon, the timings set out above showing long continuities at a landscape scale, and to varying degrees in particular locations. The notion of the 'shock of Vinča C' is probably now best translated into the peak connectivity of the system, and the timings suggest that that was anyway reached earlier, in Vinča B2. There appears to be no particular need to invoke further population movement at the start of the Vinča $\mathrm{C}$ phase, even though the models set out above suggest a probably quite rapid transition from Vinča $\mathrm{B} 2$ to Vinča $\mathrm{C}$ ceramics. But yet again, the possibility of some smallscale displacements need not entirely be excluded. It is also worth noting that the emergence of Vinča
C ceramics followed the end of the LBK, and may have coincided with a hiatus between LBK and Hinkelstein in some parts of the Rhineland (Denaire et al. in press); further east, there was probably more continuity after the end of the LBK (Link 2014), but as with beginnings, it is useful to keep an eye on the wider situation and connections.

In our view, as already hinted at in the language used throughout this paper, it is probably best in the first place to see this developed Vinča phenomenon, from Vinča B1 right through into Vinča D, as an extended social network. The overall distribution is markedly riverine, and one of us has recently sketched the connectivity in terms of 'various influences, borrowings, emulations, exchange, trade and breeding networks' (Borić 2015.158), underpinned by flows of material into sites and played out in the household settings described above. The culture historical approach has tended to construct a further sense of unifying or coherent group or ethnic identity. We have noted the warning of Voss (2015.660) about equating 'ethnonyms' with real ethnicities, and it was normal processual procedure to set that kind of interpretation aside. But it has long been apparent that the Vinča phenomenon was long-lasting and in that sense stable, which the more precise timings set out in this paper serve only to underline. Without removing local differences, there must have been much that was shared throughout the Vinča network, and from widespread, common practices there surely came a shared way of acting in and understanding the world. The virtual absence of formal or archaeologically visible mortuary practice throughout the network and the wide distributions of altars, anthropomorphic figurines (Tasić 2016), face-lids and masks, may also speak to widely shared ways of thought. Cumulatively, this perhaps gets us closer 
to Voss's (2015.658, quoting Vermeulen, Govers 1994 ) very general definition of ethnicity as a "consciousness of difference", "that is negotiated both through external debates about differences between 'us' and 'them' and through internal contests over community self-definition". But it is far from clear that the Vinča network had rigidly defined or sharp boundaries, even though from Vinča B1 onwards different kinds of ceramics were preferred in southern Hungary, for example. And whether the network at its peak projected "ideologies of shared and divergent history, ancestry, and tradition" (Voss 2015. 658), in contrast to or opposition to other contemporary cultural groupings, perhaps also remains a moot point; wider connectivity seems to have been at least as important as local or regional self-definition.

\section{Endings}

Some of the most intriguing questions raised by our study relate to the Vinča D phase. Though this now appears shorter than frequently suggested in the past, it nonetheless represents overall a substantive continuation of existing practice. Though this was the phase in which some tells began to be abandoned, others, such as Vinča-Belo Brdo itself (Tasić et al. 2015; 2016a; 2016b), continued to rise steadily, until endings perhaps mainly in the $46^{\text {th }}$ century cal BC. Simply on the basis of two well-dated sites, Vinča-Belo Brdo and Uivar (Draşovean et al. submitted), it could be the case that house burnings became more frequent in the last two centuries or so of the Vinča network. Now there are many ways to interpret house burnings, and there is not the space here to set out again all the arguments for scale and motivation (see Tasić et al. 2015.10771079). Suffice it to say that they could be seen as one symptom of changing times and increased intercommunal tensions and aggression. We have already suggested that it seems insufficient to ascribe all putative tensions to the activities of the autonomous late Vinča household, as communal dimensions still seem paramount, for example in contexts like Stubline, though we note the appearance of larger houses in some contexts such as Banjica (Tripković 2007).

The situation remains unclear, which the timings given in this paper underline. There are probable tensions, and these and perhaps other factors not yet defined, or a combination of these possibilities, appear to have brought the Vinča network and its associated ways of living to an end. Continuing the theme of tracking the Vinča and Danubian worlds in parallel, the end of the Danubian world was probably staggered across the end of the Vinča network. As with beginnings in the Vinča A phase, we still badly need a much longer list of well-dated late Vinča sites, in order to unpick the sequence and tempo of endings. Another puzzle remains. If the Vinča phenomenon unravelled because of internal tensions (however constituted), this does not seem to have been accompanied by the same kind of material regionalisation as seen for example in the late LBK (e.g., Pechtl 2015). Some regionalisation is apparent, and this paper has followed the categorisation of the Turdas culture in Transylvania as distinct from late Vinča culture (Draşovean 1996.28, 9394). But material culture including ceramics in the Vinča D phase does not appear to project the kind of much tighter regional groupings, perhaps reflective of increasing concern for local identities and interests, which seem to characterise the end of the LBK. We note again, however, the date estimates for a greater overlap between Vinča C and Vinča D ceramics than was apparent with earlier phases, and perhaps this greater variability could be an important clue to follow further at a variety of regional and local scales.

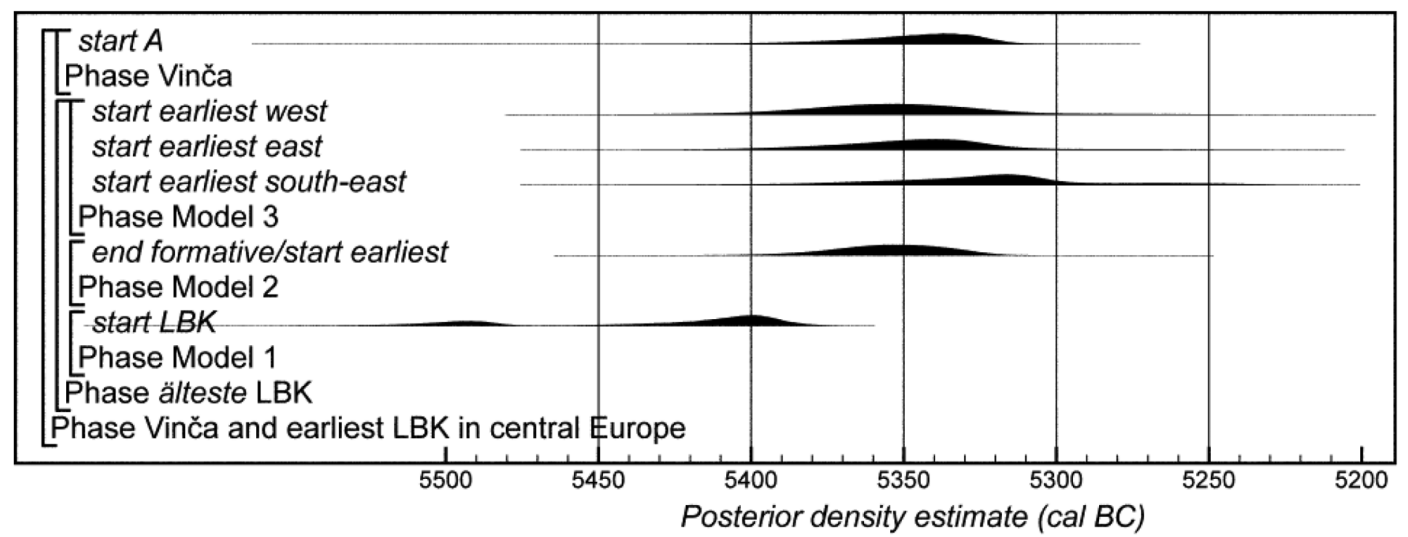

Fig. 41. Earliest Vinča A ceramics (cf. Fig. 25) in comparison to various readings of the dating of the LBK diaspora (cf. Jakucs et al. 2016.Fig 24). 


\section{Conclusions and questions for future research}

We conclude that this study indicates much more complex circumstances for the appearance of the Vinča phenomenon than envisaged in most previous approaches; that it sketches a steadily intensifying network, which reached its peak of connectivity already in the Vinča B2 phase, which was maintained through the Vinča $C$ phase and even into the Vinča D phase, though there are some signs of regionalisation in that late phase; and that Vinča ceramics remained relatively stable in the Vinča D phase, even though this is a time widely characterised by many researchers as one of tensions and even crisis. We have used the term network in preference to that of culture; the nature of the network is compatible with widely shared practices and perhaps beliefs, but connectivity rather than exclusiveness is characteristic, and sharp boundaries are not apparent.

Although these conclusions help to redefine the nature of the Vinča phenomenon, our study has raised at least as many questions as answers. In particular, it has highlighted a long list of questions about the circumstances of beginnings and endings, but there are also plenty of unresolved aspects of the long, middle part of the sequence. To answer such questions in future research, a series of challenges need to be met. The typology of Vinča ceramics could be much further refined (with no disrespect intended towards the long list of heroic pioneers and predecessors in this fundamentally important field). Correspondence analysis of the bowls in the upper portion of the Vinča-Belo Brdo stratigraphy needs to be completed, and comparable exercises could be carried out on other key assemblages across the distribution of the network. More sites should and could be radiocarbon dated, using short-life samples of known taphonomy from definable contexts, to avoid age-offsets. All these tasks are feasible, and exploitation of existing archives (as shown in the study of Vinča-Belo Brdo: Tasić et alii 2016a) is at least as important as the application of best practice in new excavations. The scale of new dating, if within a refined system of typology and seriations, need not be massive to be effective. There is every reason to be optimistic that further refinements to the chronology of the Vinča potscape, down to the precision of lifetimes and generations, can realistically be achieved in the next generation or two of research.

The supplementary information for the Vinca_Miloj cic_Model_1.oxcal and Vinca_Milojcic_Model_2.oxcal are available at http://dx.doi.org/10.4312/dp.43.1

We are grateful to Miroslav Birclin, Marcel Buric, Evanthia Kalogiropoulous, Dimitris Kloukinas, Kostas Kotsakis, Krisztian Oross, Cosmin Suciu, and Johannes van der Plicht for providing information. Kirsty Harding helped with the figures. Previously unpublished radiocarbon dates from Oreškovica were funded by the NERC Radiocarbon Facility (grant NF/2014/2/15), and we thank Duško Šljivar, Bryan Hanks, Roger Doonan, Seren Griffiths, Miroslav Kočic, and Jelena Bulatović for permission to cite them in advance of full publication. Unpublished radiocarbon dates from Masinske Njive were also funded by the NERC Radiocarbon Facility (grant NF/2011/2/5); those from Poporanj were funded by the Ministry of Culture of the Republic of Serbia as part of a project undertaken by the City Museum Vršac; and those from At were funded by the Deutsche Forschungsgemeinschaft through the Collaborative Research Center 806 'Our way to Europe' as part of project undertaken in collaboration by the Universities of Cologne and Belgrade. We are grateful to John Chapman for generously sharing his encylopaedic knowledge of the Vinča world to improve various aspects of this paper, and for providing access to his extensive library! The dating and modelling reported here have been carried out within The Times of Their Lives, funded by the European Research Council (Advanced Investigator Grant 295412), and led by Alasdair Whittle and Alex Bayliss. 


\section{References}

Alt S. M. 2006. The power of diversity: The roles of migration and hybridity in culture change. In B. M. Butler, P. D. Welch (eds.), Leadership and polity in Mississippian society. Southern Illinois University Press. Carbondale: 289-308.

Anđelković-Despotović Z., Redžić M. 1991. Arheološka iskopavanja neolitskog lokaliteta Ilića Brdo u selu Čučuge. Zbornik Narodnog muzeja u Beogradu 14: 93-98.

Anthony D. 1990. Migration in archeology: the baby and the bathwater. American Anthropologist 92: 895-914.

1997. Prehistoric migration as social process. In J. Chapman, H. Hamerow (eds.), Migrations and invasions in archaeological explanation. British Archaeological Reports IS 664. Archaeopress. 0xford: 21-32.

Babović Lj. 1986. Zbradila - Korbovo: compte-rendu des fouilles en 1981. Đerdapske Sveske III: 95-115.

1992. Rezultati detaljnog rekognosciranja neolitskih lokaliteta u širem području Bečeja. Rad vojvođanskih muzeja 34: 43-84.

Banner J. 1960. The Neolithic settlement on the Kremenjak hill at Csoka (Čoka). Acta Archaeologica Academiae Scientarium Hungaricae 12: 1-56.

Bayliss A. 2015. Quality in Bayesian chronological models in archaeology. World Archaeology 47: 677-700.

Bayliss A. and 16 co-authors. 2016. Peopling the past: creating a site biography in the Hungarian Neolithic. Bericht der Römisch-Germanischen Kommission 94: 23-91.

Benac A. 1988. Vinogradine. In Arheološki Leksikon Bosne $i$ Hercegovine Tom 2. Arheološka nalazišta. Regija 1-13. Zemaljski Muzej Bosne i Hercegovine. Sarajevo: 68.

Bentley R. A., Earls M. and O'Brien M. 2011. I'll have what she's having: mapping social behaviour. MIT Press. London.

Berciu D. 1961. Contributii la problemele neoliticului în Romînia în lumina noilor cercetări. Editura Academiei Republicii Populare Romine. Bucureşti.

Biagi P., Spataro M. 2005. New observations on the radiocarbon chronology of the Starčevo-Criş and Körös cultures. In L. Nikolova, J. Fritz and J. Higgins (eds.), Prehistoric Archaeology and Anthropological Theory and Education. Reports of Prehistoric Research Projects 6-7. Salt Lake City, Karlovo: 35-40.

Biagi P., Shennan S. and Spataro M. 2005. Rapid rivers and slow seas? New data for the radiocarbon chronology of the Balkan Peninsula. In L. Nikolova, J. Fritz and J. Higgins (eds.), Prehistoric Archaeology and Anthropological Theory and Education. Reports of Prehistoric Research Projects 6-7. Salt Lake City, Karlovo: 41-52.

Biagi P., Gratuze B. and Boucetta S. 2007. New data on the archaeological obsidian from Banat and Transylvania. In M. Spataro, P. Biagi (eds.), A short walk to the Balkans: the first farmers of the Carpathian Basin and the adjacent areas. Museo Civico di Storia Naturale. Trieste: 129-148.

Bogdanović M. 1977. Prilog proučavanju bronzanog i starijeg gvozednog doba na području centralne Srbije. Starinar 22: 145-156.

1983. Arheološka istraživanja na području centralne Srbije. In B. Vitković (ed.), Staništa: zbornik radova za političku, kulturnu i privrednu istoriju Kragujevca $i$ okoline. Istorijski arhiv Šumadije. Kragujevac: 9-26.

1988a. Rajac - Donje Grbice. In D. Srejović, N. Tasić (eds.), Vinča and its world. Serbian Academy of Sciences and Arts, Centre for Archaeological Research, Faculty of Philosophy. Belgrade: 87-88.

1988b. Brdo - Kusovac. In D. Srejović, N. Tasić (eds.), Vinča and its world. Serbian Academy of Sciences and Arts, Centre for Archaeological Research, Faculty of Philosophy. Belgrade: 71-72.

2004. Uvod. In M. Bogdanović (ed.), Grivac. Naselja Protostarčevačke $i$ Vinčanske kulture. Centar za naučna istraživanja SANU i Univerziteta u Kragujevcu, Narodni Muzej Kragujevac. Kragujevac: 9-16.

Borić D. 1996. Social dimensions of mortuary practices in the Neolithic: a case study. Starinar 47: 67-83.

2008. First households and "house societies" in European prehistory. In A. Jones (ed.), Prehistoric Europe: theory and practice. Wiley and Blackwell. Oxford: 109142.

2009. Absolute dating of metallurgical innovations in the Vinča culture of the Balkans. In T. L. Kienlin, B. W. Roberts (eds.), Metals and societies: studies in honour of Barbara S. Ottaway. Habelt. Bonn: 191-245.

2015. The end of the Vinča world: modelling the Late Neolithic to Copper Age transition and the notion of archaeological culture. In S. Hansen, P. Raczky, A. Anders and A. Reingruber (eds.), Neolithic and Copper Age between the Carpathians and the Aegean Sea: chronologies and technologies from the $6^{\text {th }}$ to the $4^{\text {th }}$ millennium BCE. Habelt. Bonn: 157-217. 
Borić D., Hanks B., Šljivar D., Doonan R., Kočić M., Bulatović J., Griffiths S. and Jacanović D. in preparation. Enclosing the Neolithic world: an early Vinča culture enclosed settlement in the Balkans.

Borojević K. 2006. Terra and Silva in the Pannonian Plain: Opovo agro-gathering in the Late Neolithic. British Archaeological Reports IS 1563. Archaeopress. Oxford.

Borović-Dimić J. 1995. Vinčanska glinena plastika sa Lađarišta. Glasnik Srpskog arheološkog društva 10: 104114.

Brandt G. and 17 co-authors. 2013. Ancient DNA reveals key stages in the formation of central European mitochondrial genetic diversity. Science 342: 257-261.

Breunig P. 1987. C14 Chronologie des vorderasiatischen, südost und mitteleuropäischen Neolitikums. Fundamenta A13. Bohlau. Köln.

Bronk Ramsey C. 2008. Deposition models for chronological records. Quaternary Science Reviews 27: 42-60.

2009. Bayesian analysis of radiocarbon dates. Radiocarbon 51: 337-360.

Bronk Ramsey C., Lee S. 2013. Recent and planned developments of the program OxCal. Radiocarbon 55: 720 730 .

Brukner B. 1961. Beletinci, Obrež - naselje vinčanske kulture. Arheološki pregled 3: 17-21.

1980. Naselje vinčanske grupe na Gomolavi (Neolitski i Ranoeneolitski sloj). Izveštaj sa iskopavanja 19671976. Rad Vojvođanskih Muzeja 26: 5-54.

1988. Die Siedlung der Vinča-Gruppe auf Gomolava (Die Wohnschicht des Spätneolithikums und Frühäneolithikums (Gomolava Ia, Ia-b und II) und der Wohnhorizont des äneolithischen Humus (Gomolava II)). In N. Tasić, J. Petrović (eds.), Gomolava. Chronologie und Stratigraphie der vorgeschichtlichen und antiken Kulturen der Donauniederung und Südosteuropas. Vojvođanski Muzej and Balkanološki Institut. Novi Sad, Belgrade: 1938 .

Bulatović A. 2003. Nalazi vinčanske kulture sa Fafosa $i$ Valača. Vranje: Narodni muzej.

Burić M. 2011. Gradac u Bapskoj - slika života istočne Hrvatske prije 7000 godina. Filozofski fakultet, odsjek za arheologiju. Zagreb.

2015. Problems of the late Neolithic chronology in Eastern Croatia. In S. Hansen, P. Raczky, A. Anders and A. Reingruber (eds.), Neolithic and Copper Age between the Carpathians and the Aegean Sea: chronologies and technologies from the $6^{\text {th }}$ to the $4^{\text {th }}$ millennium $B C E$. Archäologie in Eurasien 31. Habelt. Bonn: 143156.

Burić M., Težak-Gregl T. 2009. Bapska, a Late Neolithic settlement in Eastern Croatia - a new project. In F. Draşovean, D. L. Ciobotaru and M. Maddison (eds.), Ten years after: the Neolithic of the Balkans as uncovered by the last decade of research. Editura Marineasa. Timişoara: 85-100.

Burleigh R., Hewson A. 1979. British Museum Natural Radiocarbon Measurements XI. Radiocarbon 21: 339-352.

Burleigh R., Matthews K. and Ambers J. 1982. British Museum Natural Radiocarbon Measurements XIV. Radiocarbon 24: 229-261.

Chapman J. 1981. The Vinča culture of south-east Europe: studies in chronology, economy and society. British Archaeological Reports IS 117. Archaeopress. Oxford.

1990. The Neolithic in the Morava-Danube confluence area: a regional assessment of settlement patterns. In $\mathrm{R}$. Tringham, D. Krstić (eds.), Selevac, a Neolithic village in Yugoslavia. Institute of Archaeology. Los Angeles: $13-45$.

2000. Fragmentation in archaeology: people, places and broken objects in the prehistory of south eastern Europe. Routledge. London.

Childe V. G. 1929. The Danube in prehistory. Clarendon Press. 0xford.

Chu W., Mihailović D., Pantović I. Zeeden C., Hauck T. and Lehmkuhl F. 2016. Archaeological excavations at the site of At (Vršac, Serbia). Antiquity 90. Project gallery 352.

Čović B. 1961. Rezultati sondiranja na preistorijskom naselju u Gornjoj Tuzli. Glasnik Zemaljskog muzeja u Sarajevu 15-16: 79-139.

Crane H. R., Griffin J. B. 1972. University of Michigan Radiocarbon Dates XIV. Radiocarbon 14: 155-194.

Crnobrnja A. N. 2012. Group identities in the central Balkan Late Neolithic. Documenta Praehistorica 39: 155165.

Crnobrnja A., Simić A. and Janković M. 2009. Late Vinča culture settlement at Crkvine in Stubline. Starinar 59: 925 .

David N. 1972. On the life span of pottery, type frequencies, and archaeological inference. American Antiquity 37: 141-142. 
Denaire A., Lefranc P., Wahl J., Bronk Ramsey C., Dunbar E., Goslar T., Bayliss A., Beavan N., Bickle P. and Whittle A. in press. The cultural project: formal chronological modelling of the Early and Middle Neolithic sequence in Lower Alsace. Journal of Archaeological Method and Theory.

Dimitrijević S. 1968. Sopotsko-Lenđelska kultura. Arheološki Institut, Filozofski Fakultet Sveučilišta u Zagrebu. Zagreb.

1974. Problem stupnjevanja starčevačke kulture s posebnim obzirom na doprinos južnopanonskih nalazišta rješavanju ovog problema. Materijali 10: 59-122.

Draşovean F. 1993. Așezarea neoliticăde la Satchinez (jud. Timiş). Analele Banatului 2: 25-48.

1994. Die Stufe Vinča C im Banat. Germania 72: 409425 .

1996. Cultura Vinča târzie în Banat. Relatiile cu vecinii. Editura Mirton. Timişoara.

2013. In regards to certain Late Neolithic-Early Eneolithic synchronism from Banat and Transylvania. A Bayesian approach to published absolute dates. Studii de Preistorie 10: 13-48.

2014. On the Late Neolithic and Early Eneolithic relative and absolute chronology of the Eastern Carpathian Basin. A Bayesian approach. In W. Schier, F. Drassovean (eds.), The Neolithic and Eneolithic in Southeast Europe. New approaches to dating and cultural dynamics in the $6^{\text {th }}$ to $4^{\text {th }}$ millennium $B C$. Marie Leidorf. Rahden: 129-171.

Draşovean F., Schier W. 2009. The Neolithic tell sites of Parţa and Uivar (Romanian Banat): a comparison of their architectural sequence and organization of social space. In S. Hansen (ed.), Leben auf dem Tell als soziale Praxis. Habelt. Bonn: 165-187.

Draşovean F., Schier W., Bayliss A., Gaydarska B. and Whittle A. submitted. The lives of houses: duration, context and history at Neolithic Uivar. European Journal of Archaeo$\log y$.

Draşovean F., Ţeicu D. and Muntean M. 1996. Hodoni. Locuirile neolitice şi necropola medievală. Muzeul Banatului Montan. Reşiţa.

Dumitrescu V. 1980. The Neolithic settlement at Rast. British Archaeological Report IS 72. Archaeopress. 0xford.

Efe T. 2000. Recent investigation in inland northwest Anatolia and its contribution to Early Balkan-Anatolian connections. In S. Hiller, V. Nikolov (eds.), Karanovo III: Beiträge zum Neolithikum in Südosteuropa. Österreich-
isch-Bulgarische Ausgrabungen und Forschungen in Karanovo. Phoibos Verlag. Vienna: 171-184.

Efstratiou N., Fumanal M. P., Ferrer C., Urem Kotsos D., Curci A., Tagliocozzo A., Stratouli G., Valamoti S. M., Ntinou M., Badal E., Madella M. and Skourtopoulou A. 1998. Excavations at the Neolithic settlement of Makri, Thrace, Greece (1988-1996) - a preliminary report. Saguntum 31: $11-62$.

Facorellis Y., Sofronidou M. and Hourmouziadis G. 2014. Radiocarbon dating of the Neolithic lakeside settlement of Dispilio, Kastoria, northern Greece. Radiocarbon 56: 511-528.

Galović R. 1959. Predionica, neolitsko naselje kod Prištine. Muzej Kosova i Metohije. Priština.

Gamba C. and 16 co-authors. 2014. Genome flux and stasis during five millennia of Hungarian prehistory. Nature Communications 5: 21 October 2014. doi: 10.1038/ncom ms6257

Garašanin M. 1951. Hronologija vinčanske grupe. Arheološki Seminar. Univerza v Ljubljani. Ljubljana.

1979. Centralno-balkanska zona. In A. Benac (ed.), Praistorija jugoslavenskih zemalja II - Neolitsko doba. Akademija nauka i umjetnosti Bosne i Hercegovine. Centar za balkanološka ispitivanja. Sarajevo: 79-212.

1993. Zu den Problemen der Vinča-Gruppe in Rumanien. Balcanica 24: 7-20.

2000. Zum Begriff des Balkanisch-Anatolischen Komplexes des Späten Neolithikums. In S. Hiller, V. Nikolov (eds.), Karanovo III: Beiträge zum Neolithikum in Südosteuropa. Österreichisch-Bulgarische Ausgrabungen und Forschungen in Karanovo. Phoibos Verlag. Vienna: 343-347.

Garašanin M., Garašanin D. 1955. Neolitsko naselje u Žarkovu. Starinar 3-4 (1952-1953): 107-126.

1958. Pavlovac kod Vranja, praistorijsko naselje. Starinar 7-8(1956-1957): 398.

Garašanin D., Garašanin M. 1979. Supska "Stublina" praistorijsko naselje vinčanske grupe. Narodni muzej. Beograd.

Garašanin M., Ivanović V. 1958. Praistorija leskovačkog kraja. Narodni muzej. Leskovac.

Georgiev G. I. 1961. Kulturgruppen der Jungstein- under Kupferzeit in der Ebene von Thrazien (Südbulgarien). In J. Böhm, S. J. de Laet (eds.), L'Europe à la fin de l'âge de la pierre. Éditions de l'Academie tchécoslovaque des Sciences. Praha: 45-100. 
Gimbutas M. 1974. Anza, ca. 6500-5000 B.C.: a cultural yardstick for the study of Neolithic southeast Europe. Journal of Field Archaeology 1: 26-66.

1976. Neolithic Macedonia as reflected by excavation at Anza, southeast Yugoslavia. Institute of Archaeology. University of California. Los Angeles.

Girić M. 1988. Geschichte der Archäeologischen Ausgrabungen auf Gomolava. In N. Tasić, J. Petrović (eds.), Gomolava. Chronologie und Stratigraphie der Vorgeschichtlichen und Antiken Kulturen der Donauniederung und Südosteuropas. Vojvođanski Muzej and Balkanološki Institut SANU. Novi Sad-Belgrade: 13-17.

Gläser R. 1996. Zur absoluten Datierung der Vinča-Kultur anhand von 14C-Daten. In F. Draşovean (ed.), The Vinča culture, its role and connections. The Museum of Banat. Timişoara: 175-212.

Gligor M. 2009. Aşezarea neolitică şi eneolitică de la Alba lulia-Lumea Nouă în lumina noilor cercetări. Mega. Cluj-Napoca.

Goldman G. 1985. Battonya-Gödrösök, eine neolithische Siedlung in Südost-Ungarn. Kövizig. Békéscsaba.

Goldman G., Goldman-Szénászky J. 1991. Die SzakálhátKultur am Rand des Vinča-Kreises. Banatica 11: 193-200.

Grbić M. 1950. Gradište kod Kikinde. Starinar 1: 113-118.

Hervella M., Rotea M., Izagirre N., Constaninescu M., Alonso S., Ioana M., Lazăr C., Ridiche F., Soficaru A. D., Netea M. G. and de-la-Rua C. 2015. Ancient DNA from south-east Europe reveals different events during Early and Middle Neolithic influencing the European genetic heritage. PLoS ONE 10(6): e0128810.

Hodder I. 2012. Entangled: an archaeology of the relationships between humans and things. Wiley-Blackwell. Chichester.

Hofmann D. 2015. What have genetics ever done for us? The implications of aDNA data for interpreting identity in early neolithic central Europe. European Journal of Archaeology 18: 454-476

Hofmanová Z. and 38 co-authors. 2016. Early farmers from across Europe directly descended from Neolithic Aegeans. Proceedings of the National Academy of Sciences of USA 113: 6886-6891.

Holste F. 1939. Zur chronologische Stellung der Vinča-Keramik. Wiener Prähistorische Zeitschrift 26: 1-21.

Horváth L. 1983. Die neolithische Siedlung von SzentesIlonapart. Dissertationes Archaeologica Ser. II - 12. ELTE. Budapest.
Horváth F., Draşovean F. 2010. Remarks on the connections between the Banat and the Great Hungarian Plain at the beginning of the Middle Neolithic (Satchinez-Alföld Linear Pottery-Esztár-Vinča). Prehistoric Studies: 1-19.

Horváth F., Hertelendi E. 1994. Contribution to the 14C based absolute chronology of the Early and Middle Tisza region. Jósa András Múzeum Évkönyve 36: 111-133.

Horvatinčić N., Srdoč D., Obelić B. and Krajcar Bronić I., 1990. Radiocarbon dating of intercomparison samples at the Zagreb Radiocarbon Laboratory. Radiocarbon 32: 295-300.

Ingold T. 1993. The temporality of the landscape. World Archaeology 25: 152-174.

Jacanović D. 1988. Neolithic Sites in the Danubian Region from the mouth of the Velika Morava to Golubac. In D. Srejović, N. Tasić (eds.), Vinča and its world. Serbian Academy of Sciences and Arts. Centre for Archaeological Research, Faculty of Philosophy. Belgrade: 111-119.

Jacanović D., Đorđević A. 1990. Višeslojno praistorijsko nalazište Orašje u Dubravici. Viminacivm 4-5: 7-80.

Jacanović D., Šljivar D. 1995. Rezultati arheoloških istraživanja neolitskog naselja Konjušnica u Viteževu. Glasnik Srpskog arheološkog društva 10: 181-185.

Jakucs J., Voicsek V. 2015. The northernmost distribution of the early Vinča culture in the Danube valley: a preliminary study from Szederkény-Kukorica-dúló (Baranya County, southern Hungary). Antaeus 33: 13-54.

Jakucs J., Bánffy E., Oross K., Voicsek V., Bronk Ramsey C., Dunbar E., Kromer B., Bayliss A., Hofmann D., Marshall P. and Whittle A. 2016. Between the Vinča and Linearbandkeramik worlds: the diversity of practices and identities in the $54^{\text {th }}-53^{\text {rd }}$ centuries cal BC in south-west Hungary and beyond. Journal of World Prehistory Online First (September 2016) http://link.springer.com/article/10. 1007/s10963-016-9096-x

Jakucs J., Oross K., Bánffy E., Voicsek V., Dunbar E., Reimer P., Bayliss A., Marshall P. and Whittle A. submitted. Rows with the neighbours: the short lives of long houses at the Neolithic site of Versend-Gilencsa, Hungary. Antiquity.

Joanovič Š. 1992. Novi nalazi vinčanske kulture u jugoistočnom Banatu. Rad vojvođanskih muzeja 34: 33-42.

Joanović Š., Prikić M. 1978. Pregled nalazišta. In Lj. Reljić (ed.), Neolit južnog Banata. Narodni muzej. Pančevo: 1730 .

Jocić S. 1989. Vranin salaš - naselje vinčanske kulture kod Pančeva. Glasnik 2: 3-23. 
Jovanović B. 1965. Starija vinčanska grupa u južnom Banatu. Iskopavanje lokaliteta Trnovača kod Barande. Rad vojvođanskih muzeja 14: 15-41.

1982. Rudna glava. Najstarije rudarstvo bakra na Centralnom Balkanu. Muzej Rudarstva i Metalurgije and Arheološki Institut. Bor and Belgrade.

1994. Gradac phase in the relative chronology of the late Vinča culture. Starinar 43-44: 1-11.

Jovanović B., Glišič, J. 1961. Fafos II, Kosovska Mitrovica, naselje vinčanske kulture. Arheološki pregled 3: 22-27.

Jovanović M. 2015. Gomolava, Hrtkovci - vinčanska nekropola. Rad Muzeja Vojvodine 57: 7-60.

Jurišić A. 1960. Zaštitna iskopavanja u selu Radoinji. Starinar 11: 99-111.

Kaiser T., Voytek B. 1983. Sedentism and economic change in the Balkan Neolithic. Journal of Anthropological Archaeology 2: 323-353.

Kapuran A., Bulatović A. and Milanović D. 2016. Donje Vranje, naselje iz neolita i kasne antike. In S. Perić, A. Bulatović (eds.), Arheološka istraživanja na autoputu E75. Arheološki institute. Beograd: 115-134.

Karkanas P., Pavlopoulos K., Kouli K., Ntinou M., Tsartsidou G., Facorellis Y. and Tsourou T. 2011. Palaeoenvironments and site formation processes at the Neolithic lakeside settlement of Dispilio, Kastoria, northern Greece. Geoarchaeology: An International Journal 26: 83-117.

Katunar R. 1988. Majdan - Smederevska Palanka. In D. Srejović, N. Tasić (eds.), Vinča and its world. Serbian Academy of Sciences and Arts. Centre for Archaeological Research. Faculty of Philosophy. Belgrade: 81-82.

Kohl G., Quitta H. 1970. Berlin radiocarbon measurements IV. Radiocarbon 12: 400-420.

Korošec J. 1965. Nekateri problem podunavsko-balkanskog neolita. Situla 8: 165-175.

Kotsakis K. 2014. Domesticating the periphery: new research into the Neolithic of Greece. Pharos 20: 41-73.

Koukouli-Chryssanthaki Ch., Todorova H., Aslanis I., Vajsov I. and Valla M. 2007. Promachon-Topolnica. A GreekBulgarian archaeological project. In H. Todorova, M. Stefanovich and G. Ivanov (eds.), In the steps of James Harvey Gaul, volume 2: the Struma/Strymon river valley in prehistory. Gerda Henkel Stiftung. Sofia: 43-78.

Krstić D. 1959 Radajče kod Malče, neolitsko naselje. Starinar 9-10: 369-370.
1964. Neolitsko naselje u Vitoševcu kod Ražnja. Zbornik Narodnog muzeja u Beogradu 4: 51-63.

Laszló A. 1997. Datarea prin metoda radiocarbon în arheologie. National Museum of Romanian History. București.

Lazaridis I. and 53 co-authors. 2016. Genomic insights into the origin of farming in the ancient Near East. Nature 536: 419-424.

Lazarovici C.-M. 2006. Absolute chronology of the late Vinča culture in Romania and its role in the development of the Early Copper Age. In N. Tasić, C. Grozdanov (eds.), Homage to Milutin Garašanin. Serbian Academy of Sciences and Arts and Macedonian Academy of Sciences and Arts. Belgrade-Skopje: 277-293.

Lazarovici G. 1979. Neoliticul Banatului. Bibliotheca Musei Napocensis IV. Cluj-Napoca.

1981. Die Periodisierung der Vinča-Kultur in Rumänien. Prähistorische Zeitschrift 56: 169-196.

1987. 'Şocul' Vinča C în Transylvania. Acta Musei Porolissensis 11: 33-55.

1991. Cultura Banatului. In G. Lazarovici and F. Draşovean (eds), Cultura Vinča în România. (Origine, evolutie, legături, sinteze). Comisia muzeelor şi colecţiilor. Timişoara: 32-40.

2000. Vinča-Lengyel and Transylvania. Acta Musei Napocensis 37: 7-20.

2009. The Zau culture. In F. Draşovean, D. L. Ciobota$\mathrm{ru}$, D. L. and Maddison, M. (eds.), Ten years after: the Neolithic of the Balkans, as uncovered by the last decade of research. Editura Marineasa. Timişoara: 179217.

2010. Evolution, absolute and relative chronology of the Zau culture. In P. Kalábková, B. Kovár, P. Pavúk and J. Šuteková (eds.), PANTA RHEI: studies in chronology and cultural development of South-Eastern and Central Europe in earlier prehistory presented to Juraj Pavúk on the occasion of his $75^{\text {th }}$ birthday. Comenius University. Bratislava: 115-128.

2014. Cronologia absolute, relative şi evoluţia culturii Zau. In S. M. Colesniuc, Cultura Zau. Editura Ex Ponto. Constanţa: 15-32.

Lazić M., Sladić M. and Katunar R. 1988. Medvednjak Smederevska Palanka. In D. Srejović, N. Tasić (eds.), Vin$\check{c} a$ and its world. Serbian Academy of Sciences and Arts. Centre for Archaeological Research. Faculty of Philosophy. Belgrade: 83-84. 
Leković V. 1990. The Vinčanization of Starčevo culture. In D. Srejović, N. Tasić (eds.), Vinča and its world. Serbian Academy of Sciences and Arts. Centre for Archaeological Research. Faculty of Philosophy. Belgrade: 67-74.

1995. Neolitska Naselja. In Z. Vapa (ed.), Arheološka istraživanja duž autoputa kroz Srem. Pokrajinski zavod za zaštitu spomenika kulture. Novi Sad: 25-44.

Liebmann M. 2013. Parsing hybridity: archaeologies of amalgamation in seventeenth-century New Mexico. In J. J. Card (ed.), The archaeology of hybrid material culture. Southern Illinois University Press. Carbondale: 25-49.

2015. The Mickey Mouse kachina and other 'double objects': hybridity in the material culture of colonial encounters. Journal of Social Archaeology 15: 319-341.

Linick T. W. 1977. La Jolla natural radiocarbon measurements VII. Radiocarbon 19: 19-48.

Link T. 2006. Das Ende der neolithischen Tellsiedlungen. Ein kulturgeschichtliches Phänomen des 5. Jahrtausends v. Chr. im Karpatenbecken. Habelt. Bonn.

2014. Welche Krise? Das Ende der Linienbandkeramik aus östlicher Perspektive. In T. Link, D. Schimmelpfennig (eds.), No future? Brüche und Ende kultureller Erscheinungen. Beispiele aus dem 6.-2. Jahrtausend $v$. Chr. Welt an Erde. Kerpen-Loogh: 95-111.

Luca S. 2003. Date noi cu privire la cronologia absolută a eneoliticului timpuriu din Transilvania - Rezultatele prelucrării probelor radiocarbon de la Orăştie-Dealul Pemilor, punct X2, jud. Hunedoara. Banatica 16: 77-102.

Luca S., Diaconescu D., Georgescu A. and Suciu C. 2006. Cercetarile arheologice de la Miercurea Sibiului - Petris (jud. Sibiu), Campaniile anilor 1997-2005. Brukenthal Acta Musei I: 9-20.

Madas D. 1970. Kraljevo polje, Ćuprija: neolitsko naselje. Arheološki pregled 12: 16-18.

Madas D., Brmbolić M. 1986. Slatina, neolitsko, ranogvozdeno, rimsko i vizantijsko naselje. Arheološki pregled 26: 42-43.

Makkay J. 1990. The Protovinča problem - as seen from the northernmost frontier. In D. Srejović, N. Tasić (eds.) Vinča and its world. Serbian Academy of Sciences and Arts. Centre for Archaeological Research. Faculty of Philosophy. Belgrade: 113-122.

Mantu C. M. 2000. Relative and absolute chronology of the Romanian Neolithic. Analele Banatului VII-VIII: 75105.
Marić M. 2010. Arhitektura i idealna rekonstrukcija objekata od lepa. Kolubara 5: 69-83.

2013. Zaštitna arheološka istraživanja na lokalitetu Jaričište 1 (Rescue excavations on the Jaričište 1 site). In V. Filipović, R. Arsić and D. Antonović (eds.), Rezultati novih arheoloških istraživanja u severozapadnoj Srbiji i susednim teritorijama. Srpsko Arheološko Društvo and Zavod za zaštitu spomenika kulture Valjevo. Beograd and Valjevo: 17-31.

Marić M., Marić-Mirković N. 2011. Obrenovac kod Dimitrovgrada, naselje vinčanske kulture. Glasnik Društva konzervatora Srbije 35: 65-68.

Marijanović B. 1988a. Malo brdo. In Arheološki Leksikon Bosne i Hercegovine Tom 2. Arheološka nalazišta. Regija 1-13. Zemaljski Muzej Bosne i Hercegovine. Sarajevo: 120 .

1988b. Gradić. In Arheološki Leksikon Bosne i Hercegovine Tom 2. Arheološka nalazišta. Regija 1-13. Zemaljski Muzej Bosne i Hercegovine. Sarajevo: 77.

Marinković S. 1995 Zaštitna arheološka iskopavanja na lokaliteti Mali alas kod Čente 1971. godine. Glasnik muzeja Banata 6: 13-21.

Marinković S. 2006. Matejski brod. Narodni muzej. Zrenjanin.

Markotić V. 1984. The Vinča culture. Western Publishers. Calgary.

Marković Č. 1985. Neolit Crne Gore. Centar za arheološka istraživanja Filozofski fakultet u Beogradu. Zavod za zaštitu spomenika kulture Crne Gore. Beograd.

Mazăre P. 2005. Artefacte din os descoperite în aşezarea neolitică de la Limba, jud. Alba. In C. I. Popa, G. T. Rustoiu (eds.), Omagiu profesorului Ioan Andrițoiu cu prilejul implinirii a 65 de ani. Studii şi cercetări arheologice. Alba Iulia: 237-312.

McPherron A., Srejović D. (eds.) 1988. Divostin and the Neolithic of central Serbia. University of Pittsburgh. Pittsburgh.

Menghin 0. 1931. Weltgeschichte der Steinzeit. Anton Schroll. Wien.

Merlini M. 2011. Mortuary practices and ritual grave to consecrate a novel ancestor. In Gh. Lazarovici, C-M. Lazarovici and M. Merlini (eds.), Tărtăria and the sacred tables. Editura Mega. Cluj-Napoca: 209-238.

Merlini M., Lazarovici Gh. 2008. Settling discovery circumstances, dating and utilization of the Tărtăria tablets. Acta Terrae Septemcastrensis VII: 111-196. 
Milojčić V. 1943. Das ältere Neolithikum in Serbien. Unpublished PhD thesis. Vienna University. Vienna.

1949a. Chronologie der jüngeren Steinzeit Mittel- und Südosteuropas. Walter. Berlin.

1949b. South-eastern elements in the prehistoric civilization of Serbia. Annual of the British School at Athens 44: 258-306.

Mrkobrad D. 1982. Boljevci kod Zemuna - višeslojno nalazište. Arheološki pregled 23: 28-31.

Nikitović L. 1987. Trsine, naselje vinčanske i starčevačke kulture. Zbornik radova Narodnog muzeja u Čačku 7 : $5-28$.

1995. Neolitski lokalitet Poljčine u Ostri kod Čačka. Zbornik radova Narodnog muzeja u Čačku 25: 27-32.

Nikolić D., Vuković J. 2008. Vinča ritual vessels: archaeological context and possible meaning. Starinar 58: 51-69.

Olalde I. and 20 co-authors. 2015. A common genetic origin for early farmers from Mediterranean Cardial and Central European LBK cultures. Molecular Biology and Evolution 32: 3132-3142.

Olsen B. 2010. In defense of things: archaeology and ontology of objects. Altamira Press. Lanham.

Orton D. 2010. Both subject and object: herding, inalienability and sentient property in prehistory. World Archaeology 42: 188-200.

2012. Herding, settlement, and chronology in the Balkan Neolithic. European Journal of Archaeology 15: 5-40.

Orton D., Gaastra J. and Vander Linden M. 2016. Between the Danube and the deep blue sea: zooarchaeological meta-analysis reveals variability in the spread and development of Neolithic farming across the Western Balkans. Open Quaternary. 2: 6.

Paluch T. 2011. Maroslele-Pana: egy középsó neolitikus lelóhely a kultúrák határvidékén (Maroslele-Pana: a Middle Neolithic site at the frontier of cultures). Monographia Archaeologica 2. Szeged.

Parzinger H. 1993. Studien zur Chronologie und Kulturgeschichte der Jungstein-, Kupfer- und Frühbronzezeit zwischen Karpaten und Taurus. Römisch-germanische Forschungen. Philipp von Zabern. Mainz.

Pechtl J. 2015. Linearbandkeramik pottery and society. In C. Fowler, J. Harding and D. Hofmann (eds.), The Oxford handbook of Neolithic Europe. Oxford University Press. Oxford: 555-572.
Perić S. 2006. The Gradac period in the Neolithic settlements in the Middle Morava valley. In N. Tasić, C. Grozdanov (eds.) Homage to Milutin Garašanin. Serbian Academy of Sciences and Arts, and Macedonian Academy of Sciences and Arts. Belgrade-Skopje: 235-250.

Porčić M. 2011. An exercise in archaeological demography: estimating the population size of Late Neolithic settlements in the central Balkans. Documenta Praehistorica 38: 323-332.

2012. Social complexity and inequality in the Late Neolithic of the central Balkans: reviewing the evidence. Documenta Praehistorica 39: 167-183.

Porčić M., Blagojević T. and Stefanović S. 2016. Demography of the early Neolithic population in central Balkans: population dynamics reconstruction using summed radiocarbon probability distributions. PLOS ONE August 10, 2016. doi 10.1371/journal.pone.0160832

Quitta H., Kohl G. 1969. Neue Radiocarbondaten zum Neolithikum und zur frühen Bronzezeit Südosteuropas und der Sowjetunion. Zeitschrift für Archäologie 3: 223-255.

Rašajski R. 1962. Beluca, Pavliš, Vršac - višeslojno praistorijsko naselje. Arheološki pregled 4: 26-28.

Reimer P. J. and 29 co-authors. 2013. IntCal13 and Marine13 radiocarbon age calibration curves $0-50,000$ years cal BP. Radiocarbon 55: 1869-1887.

Renfrew C. 1970. The place of the Vinča culture in European prehistory. Zbornik radova Narodnog muzeja $\mathrm{u}$ Beogradu 6: 45-57.

Rivzi U. Z. 2015. Crafting resonance: empathy and belonging in ancient Rajasthan. Journal of Social Archaeology 15: $254-273$.

Sanev V., Stamenova M. 1989. Neolitska naselba "Stranata" vo selo Angelci. Zbornik na trudovi na Štipskiot muzej 9: 63.

Schier W. 1995. Vinča-Studien: Tradition und Innovation im Spätneolithikum des zentralen Balkanraumes am Beispiel der Gefäßkeramik aus Vinča-Belo Brdo. Unpublished Habilitation thesis. Heidelberg University. Heidelberg.

1996. The relative and absolute chronology of Vinča: new evidence from the type site. In F. Draşovean (ed.), The Vinča culture, its role and cultural connections. The Museum of Banat. Timişoara: 141-62.

2000. Measuring change: the Neolithic pottery sequence of Vinča-Belo Brdo. Documenta Praehistorica 27: 187197. 
2008. Uivar: a late Neolithic-early Eneolithic fortified tell site in western Romania. In D. Bailey, A. Whittle and D. Hofmann (eds.), Living well together? Settlement and materiality in the Neolithic of south-east and central Europe. Oxbow Books. Oxford: 54-67.

2014. The Copper Age in southeast Europe - historical epoch or typo-chronological construct? In W. Schier, F. Draşovean (eds.), The Neolithic and Eneolithic in southeast Europe: new approaches to dating and cultural dynamics in the $6^{\text {th }}$ to $4^{\text {th }}$ millennium $B C$. Marie Leidorf. Rahden: 419-435.

2016. Uivar "Gomila" und der Übergang vom Spätneolithikum zur Kupferzeit im südöstlichen Karpaten-becken im Vergleich zur Unteren Donau und dem westlichen Schwarzmeergebiet. In V. Nikolov, W. Schier (eds.), Der Schwarzmeerraum vom Neolithikum bis in die Früheisenzeit (6000-600 v. Chr.): Kulturelle Interferenzen in der zirkumpontischen Zone und Kontakte mit ihren Nachbargebieten. Marie Leidorf. Rahden: 7591.

Schier W., Draşovean F. 2004. Vorbericht über die rumänisch-deutschen Prospektionen und Ausgrabungen in der befestigen Tellsiedlung von Uivar, jud. Timiş, Rumänien (1998-2002). Praehistorische Zeitschrift 79: 145-230.

Schier W., Draşovean F., Bayliss A., Gaydarska B. and Whittle A. forthcoming. Chapter 6: Scientific dating and chronological modelling. In W. Schier, F. Draşovean (eds.), Uivar "Gomila" - a prehistoric tell settlement in Romanian Banat. Vol. I: site, architecture, stratigraphy and dating.

Shennan S. 2009. Pattern and process in cultural evolution: an introduction. In S. Shennan (ed.), Pattern and process in cultural evolution. University of California Press. Berkeley: 1-18.

Silliman S. W. 2015. A requiem for hybridity? The problem with Frankensteins, purées, and mules. Journal of Social Archaeology 15: 277-298.

Spasić M., Crnobrnja A. N. 2014. Vinča bowls with protoma. Starinar 64: 185-203.

Spasić M., Živanović S. 2015. Foodways architecture: storing, processing and dining structures at the Late Neolithic Vinča culture site at Stubline. Documenta Praehistorica 42: 219-230.

Srdoč, D., Sliepčvić A. and Planinc J. 1975. Rudjer Bošković Institute radiocarbon measurements III. Radiocarbon 17: 149-155.

Srdoč D., Sliepčević A., Obelić B. and Horvatinčić N. 1977. Rudjer Boskovic Institute radiocarbon measurements IV. Radiocarbon 19: 465-475.
Srdoč D., Horvatinčić N., Obelić B., Krajcar Bronić I. and Sliepčević A. 1987. Rudjer Boskovic Institute radiocarbon measurements IX. Radiocarbon 29: 115-134.

Stalio B. 1964. Novi metalni nalazi sa Pločnika. Zbornik Narodnog muzeja u Beogradu IV: 35-41.

1970. Aradac: "Kameniti vinogradi". Zbornik Narodnog muzeja u Beogradu 6: 73-81.

1973. Četvrti nalaz bakarnog i kamenog oruđa sa Pločnika kod Prokuplja. Zbornik Narodnog muzeja u Beogradu VII: 157-161.

Stalio B., Galović R. 1956. Naprelje, neolitsko naselje kod Novog Pazara. Narodni muzej. Beograd.

Stanković S. 1988. Ornice - Makrešani. In D. Srejović, N. Tasić (eds.), Vinča and its world. Serbian Academy of Sciences and Arts. Centre for Archaeological Research. Faculty of Philosophy. Belgrade: 85-86.

Stanković S. 1989. Neolitsko naselje kod sela Stragara. Glasnik Srpskog arheološkog društva 5: 106-113.

Starović A. 1993. Analiza keramičkih artefakata sa neolitskog naselja u Petnici. Petničke Sveske 29: 34-72.

Stuiver M., Reimer P. 1993. Extended 14C database and revised CALIB radiocarbon calibration program. Radiocarbon 35: 215-230

Suciu C. 2009. Cultura Vinča in Transylvania. ALTIP. Alba Iulia.

2011. Early Vinča culture dynamic in south-eastern Transylvania. In S. Mills, P. Mirea (eds.), The lower Danube in prehistory: landscape changes and humanenvironment interactions. Editura Renaissance. București: $75-85$.

Szécsényi-Nagy A. and 27 co-authors. 2015. Tracing the genetic origin of Europe's first farmers reveals insights into their social organization. Proceedings of the Royal Society B 282/1085, 2015, 20150339. DOI: 10.1098/rspb. 2015.0339.

Šljivar D., Jacanović D. 1996. Veliko Laole, "Belovode" naselje vinčanske grupe. Glasnik Srpskog arheloškog društva 11: 185-189.

Šljivar D., Kuzmanović Cvetković J. P. and Živković J. 2010. Belovode, Pločnik; on copper metallurgy in the Vinča culture. Zbornik Narodnog muzeja u Beogradu XX: 27-45.

Tasić N. 1958. Žitkovac i neki problemi relativnog hronološkog odnosa neolitskih i eneolitskih naselja na Kosovu 
i u dolini Ibra. Glasnik Muzeja Kosova i Metohije 3: 1146.

1960. Zavrna istraivanja na praistorijskom naselju kod Valaca. Glasnik Muzeja Kosova i Metohije 45: 11-82.

1961. Obala Dunava, Zemun-praistorijska naselja. Arheološki pregled 3: 29-31.

1965. Mala strana, Laćarak, Sremska Mitrovica - neolitsko naselje vinčanske grupe. Arheološki pregled 7: 14- 16.

1988. Comparative C-14 dates for the Neolithic settlements in Serbia. In D. Srejović, N. Tasić (eds.), Vinča and its world. Serbian Academy of Sciences and Arts. Centre for Archaeological Research. Faculty of Philosophy. Belgrade: 45-47.

2011. Anthropomorphic figurines from Vinča excavations 1998-2009. Documenta Praehistorica 38: 149157.

2016. Vinča figurines: identities hidden and revealed. In K. Bačvarov, R. Gleser (eds.), Southeast Europe and Anatolia in prehistory: essays in honor of Vassil Nikolov on his 65th anniversary. Habelt. Bonn: 357-373.

Tasić N., Marić M., Penezić K., Filipović D., Borojević K., Borić D., Reimer P., Russell N., Bayliss A., Barclay A., Gaydarska B. and Whittle A. 2015. The end of the affair: formal chronological modelling for the top of the Neolithic tell of Vinča-Belo Brdo. Antiquity 89: 1064-1082.

Tasić N., Marić M., Bronk Ramsey C., Kromer B., Barclay A., Bayliss A., Beavan N., Gaydarska B. and Whittle A. 2016a. Vinča-Belo Brdo, Serbia: the times of a tell. Germania 93: $1-76$.

Tasić N., Marić M., Filipović D., Penezić K., Dunbar E., Reimer P., Barclay A., Bayliss A., Gaydarska B. and Whittle A. 2016b. Interwoven strands for refining the chronology of the Neolithic tell of Vinča-Belo Brdo, Serbia. Radiocarbon 58/4, published online: 30 August 2016. Doi: 10.1017/ RDC.2016.56

Tasić N., Srejović D. and Stojanović B. 1990. Vinča - centre of the Neolithic culture of the Danubian region. Centre for Archaeological Research, Faculty of Philosophy. Belgrade.

Tasić N., Tomić E. 1969. Crnokalačka Bara. Naselje starčevačke i vinčanske kulture. Narodni Muzej Kruševac. Arheološko društvo Jugoslavije. Beograd.

Todorova H. 1990. Ein mittelaneolithisches Haus aus Poduene (Sofia) aus der Vinca D2 Zeit. In D. Srejović, N. Tasić (eds.), Vinča and its world. Serbian Academy of Sciences and Arts. Centre for Archaeological Research. Faculty of Philosophy. Belgrade: 155-165.
Todorović J. 1966. Kremenite njive, Barajevo, Obrenovac - neolitsko naselje. Arheološki pregled 8: 18-19.

1968. Grabovac, Đurića vinogradi, Obrenovac - naselje starčevačke i vinčanske kulture. Arheološki pregled 11: 11-13.

Todorović J., Cermanović A. 1961. Banjica, naselje vinčanske grupe. Muzej grada Beograda. Beograd.

Tomić E., Vukadin 0. 1969. Vitkovo, Aleksandrovac - naselje vinčanske kulture. Arheološki pregled 11: 21-22.

Trbuhović V., Vasiljević M. 1970. Jela, Šabac - praistorijsko naselje. Arheološki pregled 12: 23-25.

1975. „Obrovci“ poseban tip neolitskih naselja u zapadnoj Srbiji. Starinar 24-25: 157-161.

Tringham R., Brukner B., Kaiser T., Borojević K., Russell N., Stehli P., Stevanović M. and Voytek B. 1992. Excavations at Opovo 1985-7: socioeconomic change in the Balkan Neolithic. Journal of Field Archaeology 19: 351-86.

Tringham R., Brukner B. and Voytek B. 1985. The Opovo project: a study of socioeconomic change in the Balkan Neolithic. Journal of Field Archaeology 12: 425-444.

Tringham R., Krstić D. 1990a. Introduction: The Selevac Archaeological Project. In R. Tringham and D. Krstić (eds.), Selevac: a Neolithic village in Yugoslavia. University of California Press. Los Angeles: 1-12.

1990b. Selevac and the transformation of southeast European prehistory. In R. Tringham, D. Krstić (eds.), Selevac: a Neolithic village in Yugoslavia. University of California Press. Los Angeles: 567-616.

(eds.) 1990c. Selevac: a Neolithic village in Yugoslavia. University of California Press. Los Angeles.

Tripković B. 2007. Domaćinstvo i prostor u kasnom neolitu. Vinčansko naselje na Banjici (Household and space in the Late Vinča settlement at Banjica). Srpsko arheološko društvo. Beograd.

2010. House(hold) continuities in the central Balkans, 5300-4600 BC. Opuscula Archaeologica 33: 7-28.

2011. Containers and grains: food storage and symbolism in the central Balkans (Vinča period). Documenta Praehistorica 38: 159-172.

2013. Domaćinstvo i zajednica. Kućne i naseobinske istorije u kasnom neolitu Centralnog Balkana. Filozofski fakultet. Univerzitet u Beogradu. Beograd.

Tripković B, Milić M. 2009. The origin and exchange of obsidian from Vinča-Belo Brdo. Starinar 58: 71-86. 
Trogmayer 0. 1964. Megjegyzések a Körös csoport relatív idôrendjéhez (Remarks to the relative chronology of the Körös group). Archaeologiai Értesitó 91: 67-86.

1980. Újabb adatok a vonaldíszes kerámia relatív idôrendjéhez (Neue Beiträge zur relativen Chronologie der Linearkeramik). Móra Ferenc Múzeum Evkönyve 1978/ 79: 297-301.

Valović S. 1983. Neolitsko naselje u Ratini i njegovo mesto u vinčanskom kulturnom kompleksu. Zbornik radova Narodnog muzeja u Čačku 13: 33-45.

1987. Okruglica - višeslojni lokalitet starčevačke i vinčanske kulture u Vitanovcu kod Kraljeva. Naša prošlost (Kraljevo) 2: 33-65.

Vander Linden M., Pandžić I. and Orton D. 2014. New radiocarbon dates for the Neolithic period in Bosnia and Herzegovina. Godišnjak 43: 7-34.

Van Dyke R. M. 2015. Materiality in practice: an introduction. In R. M. Van Dyke (ed.), Practicing materiality. University of Arizona Press. Tucson: 3-32.

Vermeulen H., Govers C. (eds.) 1994. The anthropology of ethnicity: beyond ethnic groups and boundaries. Het Spinhuis. Amsterdam.

Vilotijević D. 1965. Nove Zemlje, Žabalj - višelsojno praistorijsko nalazište. Arheološki pregled 7: 31-32.
Vogel J. C., Waterbolk H. T. 1963. Groningen radiocarbon dates IV. Radiocarbon 5: 163-202.

Voss B. L. 2015. What's new? Rethinking ethnogenesis in the archaeology of colonialism. American Antiquity 80: 655-670.

Vuković J. 2011. Late Neolithic pottery standardization: application of statistical analyses. Starinar 41: 81-100.

Vuković J., Vitezović S. and Milanović D. 2016. Pavlovac Kovačke njive - neolitski horizonti. In S. Perić and A. Bulatović (eds.), Arheološka istraživanja na autoputu E75. Arheološki institut. Beograd: 167-204.

Ward G. K., Wilson S. R. 1978. Procedures for comparing and combining radiocarbon age determinations: a critique. Archaeometry 20: 19-31.

Waterbolk H. 1988. C14-Datierungen von Gomolava. In N. Tasić, J. Petrović (eds.), Gomolava: Symposium. Muzej Vojvodine. Novi Sad: 117-121.

Whittle A. 1996. Europe in the Neolithic: the creation of new worlds. Cambridge University Press. Cambridge.

Whittle A., Bartosiewicz L., Borić D., Pettitt P. and Richards M. 2002. In the beginning: new radiocarbon dates for the Early Neolithic in northern Serbia and south-east Hungary. Antaeus 25: 63-117. 
Tab. 1. Summary of radiocarbon dating evidence considered in this review 19.

\begin{tabular}{|c|c|c|c|c|}
\hline Site & $\left|\begin{array}{c}\text { No. of }{ }^{14} \mathrm{C} \\
\text { results }\end{array}\right|$ & $\begin{array}{c}\text { No. of }{ }^{14} \mathrm{C} \text { results } \\
\text { (excluded) }\end{array}$ & $\begin{array}{c}\text { No. of }{ }^{14} \mathrm{C} \\
\text { results (TPQ) }\end{array}$ & References \\
\hline \multicolumn{5}{|l|}{ Danube upstream of Tisza } \\
\hline Szederkény-Kukorica-dűlő & 41 & 2 & & Jakucs et al. 2016.Tab. 1 \\
\hline Versend & 68 & 2 & & Jakucs et al. submitted.Tab. 1 \\
\hline Bapska & 8 & 1 & 1 & Table 2 \\
\hline \multicolumn{5}{|l|}{ Tisza and Mureş } \\
\hline Maroslele Pana & 5 & & & Table 2 \\
\hline At & 4 & & 1 & Table 2 \\
\hline Potporanj & 3 & & 2 & Table 2 \\
\hline Ószentiván 8 & 4 & & 4 & Kohl, Quitta 1970 \\
\hline Tiszasziget & 1 & & 1 & Table 2 \\
\hline Satchinez & 1 & & & Table 2 \\
\hline Hodoni & 2 & & & Table 2 \\
\hline Uivar & 182 & 27 & 86 & Schier et al. forthcoming. Tabs. 6.2-6.6 \\
\hline Tărtăria & 3 & 1 & 1 & Table 2 \\
\hline Limba & 1 & 1 & & Biagi et al. 2005.49 \\
\hline Cauce Cave & 1 & 1 & & Paolo Biagi, pers. comm. \\
\hline Orăştie-Dealul Pemilor, punct $X_{2}$ & 3 & 3 & & Luca 2003 \\
\hline Cârcea Viaduct & 8 & 8 & & Mantu 2000.99; Biagi, Spataro 2005.37 \\
\hline Miercurea Sibiului-Petriş & 4 & 1 & 1 & Biagi et al. 2007. Fig. 3; Luca et al. 2006.17 \\
\hline \multicolumn{5}{|l|}{ Sava catchment } \\
\hline Lupljanica & 1 & & 1 & Table 2 \\
\hline Gornja Tuzla & 5 & 3 & 2 & Table 2 \\
\hline Gomolava & 32 & 3 & 15 & $\begin{array}{l}\text { Borić 2009.Tab. 5; Orton 2012.Tab. 2; } \\
\text { Waterbolk 1988. Beilage } 1\end{array}$ \\
\hline Petnica & 7 & & & Borić 2009.Tab. 6; Orton 2012.Tab. 2 \\
\hline Masinske Njive & 3 & & & Table 2 \\
\hline Jaričište 1 & 1 & & & Table 2 \\
\hline \multicolumn{5}{|l|}{ Belgrade area } \\
\hline Vinča Belo-Brdo & 85 & 2 & 7 & Tasić et al. 2016a.Tab. 2 \\
\hline Opovo & 13 & & 2 & Orton 2012.Tab. 2; Table 2 \\
\hline Banjica & 3 & 1 & 2 & Table 2 \\
\hline \multicolumn{5}{|l|}{ Central Serbia } \\
\hline Grivac & 6 & 1 & 5 & Table 2 \\
\hline Divostin II & 11 & 2 & 8 & McPherron, Srejović 1988; Borić 2009 \\
\hline \multicolumn{5}{|l|}{ Morava catchment } \\
\hline Anzabegovo & 2 & & 2 & Table 2 \\
\hline Belovode & 9 & 1 & 3 & Borić 2009.Tab. 2 \\
\hline Pločnik & 8 & & & Table 2 \\
\hline Oreškovica & 6 & & & Table 2 \\
\hline Selevac & 12 & & 7 & Table 2 \\
\hline Predionica & 1 & & 1 & Table 2 \\
\hline Valač & 1 & & & Table 2 \\
\hline Beran-Krš & 2 & & 2 & Table 2 \\
\hline Donje Vranje & 1 & & 1 & Table 2 \\
\hline \multicolumn{5}{|l|}{ Danube downstream of Vinča } \\
\hline Liubcova & 1 & & & Table 2 \\
\hline Gornea & 1 & & 1 & Table 2 \\
\hline Rudna Glava & 14 & 6 & & Borić 2009.Tab. 1 \\
\hline
\end{tabular}

19 Additionally, five thermoluminescence (TL) ages are reported on sherds from Feature 121 at Divostin II by McPherron and Srejović (1988.Ch. 4). These measurements were made using the fine-grain technique (Zimmerman 1971), although no checks were made for anomalous fading (Wintle 1973) nor radon escape (Desai, Aitken 1974). Given the provisional nature of these measurements, no error is quoted for the measurements on each sherd and so they cannot be included in the modelling presented here. Similarly, no error is reported for the average magnetic inclination and declination measurements made from samples from Houses 14, 15, and 16 at Divostin II, two houses from Grivac, and the middle of the Vinča layer at Gomolava, which are also reported by McPherron and Srejović (1988.Ch. 4). Again, this prevents these measurements from being calibrated and included in the chronological models. 
Tab. 2. Radiocarbon determinations and related stable isotopic measurements for samples associated with Vinča ceramics (all stable isotope measurements were made using Isotope Ratio Mass Spectrometry, except those marked * which were made by Accelerator Mass Spectrometry).

\begin{tabular}{|c|c|c|c|c|c|c|c|}
\hline Site & $\begin{array}{l}\text { Laboratory } \\
\text { number }\end{array}$ & Material and stratigraphic details & $\left|\begin{array}{c}\text { Radiocarbon } \\
\text { age (BP) }\end{array}\right|$ & $\begin{array}{l}\delta^{13} \mathrm{C} \\
(\% \circ)\end{array}$ & $\begin{array}{l}\delta^{15} \mathrm{~N} \\
(\% \circ)\end{array}$ & C:N & References \\
\hline Bapska & Bln-348 & $\begin{array}{l}\text { Sample } 1 \text {, charcoal, Ulmus sp. from } \\
\text { foundation of house } 2-A ; 1.4 \mathrm{~m} \text { in } \\
\text { Dimitrijević } 1964 \text { trench associated } \\
\text { with a Vinča } C \text { vessel }\end{array}$ & $5820 \pm 80$ & & & & $\begin{array}{l}\text { Quitta, Kohl 1969; } \\
\text { Dimitrijević 1968.92 }\end{array}$ \\
\hline Bapska & Beta-241657a & $\begin{array}{l}\text { Charred Triticum dicoccum from } \\
\text { house } 2 \text { associated with Vinča C/D } \\
\text { pottery (Burić 2015.150) }\end{array}$ & $5710 \pm 40$ & -23.6 & & & Burić 2015; 2011 \\
\hline Bapska & Beta-241657b & $\begin{array}{l}\text { Carbonised wheat grains from a con- } \\
\text { centration with traces of a wooden } \\
\text { framework from behind house } 1\end{array}$ & $5690 \pm 40$ & -23.6 & & & $\begin{array}{l}\text { Burić, Tezac-Gregl } \\
\text { 2009; Burić 2011; } 2015\end{array}$ \\
\hline Bapska & Beta-241659 & $\begin{array}{l}\text { Charred unidentified animal bone } \\
\text { from exterior of house } 2 \text { building } \\
\text { level associated with Vinča C/D } \\
\text { pottery (Burić 2015.150) } \\
\end{array}$ & $5660 \pm 40$ & -23.7 & & & Burić 2011; 2015 \\
\hline Bapska & OxA-23592 & $\begin{array}{l}\text { Unidentified animal bone from exterior } \\
\text { of house } 2 \text { building level associated } \\
\text { with Vinča C/D pottery (Burić 2015.150) }\end{array}$ & $5714 \pm 31$ & -20.3 & & & Burić 2011; 2015 \\
\hline Bapska & OxA-23593 & $\begin{array}{l}\text { Unidentified animal bone from build- } \\
\text { ing level of houses } 1 \text { and } 2\end{array}$ & $5715 \pm 33$ & -20.2 & & & Burić 2011; 2015 \\
\hline Bapska & Beta-333534 & $\begin{array}{l}\text { Charred grains from house } 2 \text { associated } \\
\text { with a Vinča C/D vessel (Burić 2015.150) }\end{array}$ & $5700 \pm 40$ & & & & Burić 2015 \\
\hline $\begin{array}{l}\text { Maroslele- } \\
\text { Pana }\end{array}$ & Poz-28647 & $\begin{array}{l}\text { Unidentified animal bone from pit } 119 \\
\text { containing a few diagnostic sherds, } \\
\text { some of which resemble Vinča A1-A2 } \\
\text { forms, while others resemble early } \\
\text { Alföld LBK material }\end{array}$ & $6290 \pm 40$ & & & & $\begin{array}{l}\text { Paluch 2011. Figs. 115- } \\
116\end{array}$ \\
\hline $\begin{array}{l}\text { Maroslele- } \\
\text { Pana }\end{array}$ & Poz-42773 & $\begin{array}{l}\text { Unidentified animal bone from pit } 114 \\
\text { containing diagnostic Vinča } \mathrm{A}_{1}-\mathrm{A}_{2} \\
\text { pottery and diagnostic early } \\
\text { Alföld LBK material }\end{array}$ & $6255 \pm 40$ & & & & $\begin{array}{l}\text { Paluch 2011. Figs. 102- } \\
114\end{array}$ \\
\hline $\begin{array}{l}\text { Maroslele- } \\
\text { Pana }\end{array}$ & Poz-28646 & $\begin{array}{l}\text { Unidentified animal bone from pit } 103 \\
\text { containing diagnostic Vinča } \mathrm{A}_{1}-\mathrm{A}_{2} \\
\text { pottery and diagnostic early } \\
\text { Alföld LBK material }\end{array}$ & $6280 \pm 40$ & & & & $\begin{array}{l}\text { Paluch 2011. Figs. 92- } \\
101\end{array}$ \\
\hline $\begin{array}{l}\text { Maroslele- } \\
\text { Pana }\end{array}$ & Poz-28645 & $\begin{array}{l}\text { Unidentified animal bone from pit } 102 \\
\text { containing a few diagnostic sherds, } \\
\text { some of which resemble Vinča } \mathrm{A}_{1}-\mathrm{A}_{2} \\
\text { forms }\end{array}$ & $6280 \pm 40$ & & & & $\begin{array}{l}\text { Paluch 2011. Figs. 90- } \\
91\end{array}$ \\
\hline $\begin{array}{l}\text { Maroslele- } \\
\text { Pana }\end{array}$ & Poz-28644 & $\begin{array}{l}\text { Unidentified animal bone from pit } 85 \\
\text { containing diagnostic Vinča } A_{1}-A_{2} \\
\text { pottery and a few fragments in } \\
\text { early Alföld LBK style }\end{array}$ & $6200 \pm 50$ & & & & $\begin{array}{l}\text { Paluch 2011. Figs. 62- } \\
89\end{array}$ \\
\hline$\overline{\text { At }}$ & Col-3245 & $\begin{array}{l}\text { Pig mandible from layer } 8 \text {, base of pit } \\
\text { 1, associated with Vinča C/D pottery }\end{array}$ & $5739 \pm 41$ & $-21.0 *$ & & & Chu et al. 2016 \\
\hline$\overline{\text { At }}$ & Col-3246 & $\begin{array}{l}\text { Unidentified charcoal from layer } 11 \\
\text { feature } 3 . \text { A concentration of fired } \\
\text { clay from the oven }\end{array}$ & $5675 \pm 43$ & $-24 \cdot 7^{*}$ & & & Chu et al. 2016 \\
\hline$\overline{\text { At }}$ & Col-3248 & $\begin{array}{l}\text { Right nasal bovid bone from layer } 11 \\
\text { feature } 2 a \text {, from large concentration of } \\
\text { ash next to the fired clay in feature } 3 \text {. }\end{array}$ & $5905 \pm 41$ & $-20.0 *$ & & & Chu et al. 2016 \\
\hline At & OxA-8595 & $\begin{array}{l}\text { Bone tool from pit } 1 \text { associated with } \\
\text { Vinča C/D pottery }\end{array}$ & $5660 \pm 65$ & -20.2 & & & Whittle et al. 2002 \\
\hline
\end{tabular}




\begin{tabular}{|c|c|c|c|c|c|c|c|}
\hline Site & $\begin{array}{l}\text { Laboratory } \\
\text { number }\end{array}$ & Material and stratigraphic details & $\left|\begin{array}{c}\text { Radiocarbon } \\
\text { age (BP) }\end{array}\right|$ & $\begin{array}{l}\delta^{13} \mathrm{C} \\
(\% \circ)\end{array}$ & $\begin{array}{l}\delta^{15} \mathrm{~N} \\
(\% \circ)\end{array}$ & C:N & References \\
\hline Potporanj & $\begin{array}{l}\text { MAMS- } \\
22666\end{array}$ & $\begin{array}{l}\text { Unidentified charcoal from last habita- } \\
\text { tion level, after the removal of the } \\
\text { house debris in trench } 2 \text { associated } \\
\text { with Vinča B to Vinča C pottery }\end{array}$ & $6156 \pm 30$ & $-18.7^{*}$ & & & \\
\hline Potporanj & $\begin{array}{l}\text { MAMS- } \\
22667\end{array}$ & $\begin{array}{l}\text { Unidentified charcoal from the lowest } \\
\text { level, house floor level, trench } 2 \\
\text { associated with Vinča A pottery }\end{array}$ & $6139 \pm 29$ & $-16.8 *$ & & & \\
\hline Potporanj & $\begin{array}{l}\text { MAMS- } \\
22668\end{array}$ & $\begin{array}{l}\text { Unidentified animal bone from relative } \\
\text { depth of } 1.64 \mathrm{~m} \text { in trench } 2 \text { associated } \\
\text { with Vinča B2 pottery }\end{array}$ & $6211 \pm 25$ & $-24 \cdot 4 *$ & & 3.1 & \\
\hline Tiszasziget & Bln-1631 & $\begin{array}{l}\text { Unidentified charcoal from Pit } 1 \\
\text { associated with Vinča A pottery } \\
\text { (Horváth, Hertelendi 1994.125) }\end{array}$ & $6285 \pm 60$ & & & & $\begin{array}{l}\text { Horváth, Hertelendi } \\
1994\end{array}$ \\
\hline Satchinez & Deb-2579 & $\begin{array}{l}\text { Antler from pit } 4^{20} \text { associated with } \\
\text { Vinča A pottery (Mantu 2000.98) }\end{array}$ & $6270 \pm 40$ & & & & Mantu 2000 \\
\hline Hodoni & Deb-1963 & $\begin{array}{l}\text { Antler from Pit } 4 \text { associated with } \\
\text { Vinča C pottery (Draşovean 1994.411) }\end{array}$ & $5880 \pm 60$ & & & & Draşovean 1994 \\
\hline Hodoni & Deb-2018 & $\begin{array}{l}\text { Antler from Pit } 4 \text { associated with } \\
\text { Vinča C pottery (Gläser 1996.196) }\end{array}$ & $5870 \pm 60$ & & & & Gläser 1996 \\
\hline Tărtăria & $R-1631$ & $\begin{array}{l}\text { Partial human burial from ritual pit } \\
\text { associated with Vinča Bi pottery }\end{array}$ & $6310 \pm 65$ & & & & Merlini et al. 2008.156 \\
\hline Tărtăria & $R-1655$ & $\begin{array}{l}\text { Unidentified animal bone from base of } \\
\text { pit } B 2 \text { associated with Vinča } B 1 \text { pottery }\end{array}$ & $6215 \pm 65$ & & & & Merlini et al. 2008.156 \\
\hline $\begin{array}{l}\text { Miercurea } \\
\text { Sibiului- } \\
\text { Petriş }\end{array}$ & GrA-33127 & $\begin{array}{l}\text { Single charred grain of Triticum dicoc- } \\
\text { cum from layer Ila in pit } 18 \text {, which } \\
\text { contained diagnostic assemblage of } \\
\text { Vinča B ceramics }\end{array}$ & $6475 \pm 40$ & -22.4 & & & Biagi et al. 2007. Fig. 3 \\
\hline $\begin{array}{l}\text { Miercurea } \\
\text { Sibiului- } \\
\text { Petriş }\end{array}$ & GrA-43076 & $\begin{array}{l}\text { Charred residue on pottery sherd from } \\
\text { pit } 18 \text {, which contained diagnostic } \\
\text { assemblage of Vinča B ceramics }\end{array}$ & $6160 \pm 50$ & -26.1 & & & \\
\hline $\begin{array}{l}\text { Miercurea } \\
\text { Sibiului- } \\
\text { Petriş }\end{array}$ & GrN-29053 & $\begin{array}{l}\text { Cattle calcaneum from house } 11, \\
\text { level IIb associated with diagnostic } \\
\text { assemblage of Vinča B ceramics }\end{array}$ & $6350 \pm 130$ & -20.8 & & & Luca et al. 2006.17 \\
\hline $\begin{array}{l}\text { Miercurea } \\
\text { Sibiului- } \\
\text { Petriş }\end{array}$ & GrN-30500 & $\begin{array}{l}\text { Red deer astragalus from pit } 3 \text {, } \\
\text { level IIb, which contained diagnostic } \\
\text { assemblage of Vinča B ceramics }\end{array}$ & $6200 \pm 60$ & -19.1 & & & Biagi et al. 2007. Fig. 3 \\
\hline Lupljanica & $M-2455$ & $\begin{array}{l}\text { Unidentified charcoal from } 1.3 \mathrm{~m} \text { below } \\
\text { ground surface in feature } 11 / 1970 \text {, the } \\
\text { lower building level of Late Neolithic } \\
\text { structure in the southwest part of the } \\
\text { site, associated with Vinča D pottery } \\
\text { (Breunig 1987.107) }\end{array}$ & $5600 \pm 200$ & & & & $\begin{array}{l}\text { Breunig 1987.107; } \\
\text { Crane, Griffin 1972. } \\
\text { 190-191 }\end{array}$ \\
\hline $\begin{array}{l}\text { Gornja } \\
\text { Tuzla }\end{array}$ & Bln-349 & $\begin{array}{l}\text { Charcoal, Quercus sp. from burnt } \\
\text { wooden stucture at } 3.63 \mathrm{~m} \text { in Sonda } \\
\text { II/I-8, kop } 26 \text { associated with Vinča C } \\
\text { pottery (Quitta, Kohl 1969.233) }\end{array}$ & $5710 \pm 100$ & & & & Quitta, Kohl 1969 \\
\hline $\begin{array}{l}\text { Gornja } \\
\text { Tuzla }\end{array}$ & GrN-1974 & $\begin{array}{l}\text { Unidentified charcoal (charred beam at } \\
\text { the depth of } 3.5 \mathrm{~m} \text { ) associated with Vin- } \\
\text { ča C pottery (Vogel, Waterbolk 1963.183) }\end{array}$ & $5580 \pm 60$ & & & & Vogel, Waterbolk 1963 \\
\hline $\begin{array}{l}\text { Masinske } \\
\text { Njive }\end{array}$ & OxA-26303 & $\begin{array}{l}\text { Bos/Cervus from Feature 1.31/4, O.S. 12, } \\
\text { Sq. } \geq 8 \text { associated with Vinča B pottery } \\
\text { (M. Spasić, pers. comm.) }\end{array}$ & $6211 \pm 35$ & -21.5 & 8.1 & & \\
\hline $\begin{array}{l}\text { Masinske } \\
\text { Njive }\end{array}$ & OxA-26304 & $\begin{array}{l}\text { Bos taurus from Feature 1.31/4, O.S. 12, } \\
\text { Sq. } \geq 8 \text { associated with Vinča B pottery } \\
\text { (M. Spasić, pers. comm.) }\end{array}$ & $6267 \pm 36$ & -21.2 & 7.8 & & \\
\hline $\begin{array}{l}\text { Masinske } \\
\text { Njive }\end{array}$ & OxA-26305 & $\begin{array}{l}\text { Cervus elaphus from Feature 1.31/9, } \\
\text { O.S. O5, Sq. Y4 associated with Vinča B } \\
\text { pottery (M. Spasić, pers. comm.) }\end{array}$ & $6235 \pm 37$ & -22.6 & 7.1 & & \\
\hline
\end{tabular}

20 Draşovean (2014.154, fn 10) reports that this sample came from pit 1. This was, however, a typographical error. 


\begin{tabular}{|c|c|c|c|c|c|c|c|}
\hline Site & \begin{tabular}{|l} 
Laboratory \\
number
\end{tabular} & Material and stratigraphic details & $\left|\begin{array}{c}\text { Radiocarbon } \\
\text { age (BP) }\end{array}\right|$ & $\begin{array}{l}\delta^{13} C \\
(\% \circ)\end{array}$ & $\begin{array}{l}\delta^{15} \mathrm{~N} \\
(\% \circ)\end{array}$ & $\mathrm{C}: \mathrm{N}$ & References \\
\hline Jaričište 1 & $\begin{array}{c}\text { NOSAMS- } \\
78623\end{array}$ & $\begin{array}{l}\text { A singe flax seed from feature } 1.137 \text { (pit } \\
\text { infill) associated with Vinča A pottery }\end{array}$ & $6260 \pm 35$ & & & & \\
\hline Opovo & CAMS-4411 & $\begin{array}{l}\text { Unidentified charcoal from Feature } 41 \\
\text { (locus 1861) associated with } \\
\text { Vinča C pottery }\end{array}$ & $6030 \pm 60$ & -25.0 & & & \\
\hline Opovo & CAMS- 4413 & $\begin{array}{l}\text { Unidentified charcoal from Feature } 41 \\
\text { (locus } 1800 \text { ) associated with } \\
\text { Vinča C pottery }\end{array}$ & $5990 \pm 60$ & -25.0 & & & \\
\hline$\overline{\text { Banjica }}$ & $\mathrm{GrN}-1542$ & $\begin{array}{l}\text { Unidentified charcoal associated with } \\
\text { Vinča D pottery } \\
\text { (Vogel, Waterbolk 1963.185) }\end{array}$ & $5710 \pm 90$ & & & & $\begin{array}{l}\text { Vogel, Waterbolk } \\
1963.184-185\end{array}$ \\
\hline$\overline{\text { Banjica }}$ & $\mathrm{GrN}-1536$ & $\begin{array}{l}\text { Charcoal/charred grain from House } 7 \text {, } \\
\text { horizon III associated with Vinča D } \\
\text { pottery (Vogel, Waterbolk 1963.184) }\end{array}$ & $5670 \pm 120$ & & & & $\begin{array}{l}\text { Vogel, Waterbolk } \\
1963.184\end{array}$ \\
\hline Grivac & Z-1508 & $\begin{array}{l}\text { Unidentified charcoal from Trench A, } \\
\text { level } 9 \text { associated with Vinča C pottery }\end{array}$ & $6000 \pm 140$ & & & & Srdoč et al. 1987 \\
\hline Grivac & Bln-868 & $\begin{array}{l}\text { 'Burnt earth' from Trench B, under burnt } \\
\text { house associated with Vinča C pottery }\end{array}$ & $6070 \pm 100$ & & & & $\begin{array}{l}\text { McPherron, Srejović } \\
\text { 1988.Tab. 14.1 }\end{array}$ \\
\hline Grivac & Bln-872 & $\begin{array}{l}\text { Unidentified charcoal from Trench A, } \\
\text { level 4, burnt house floor associated } \\
\text { with Vinča C pottery }\end{array}$ & $5915 \pm 100$ & & & & $\begin{array}{l}\text { McPherron, Srejović } \\
\text { 1988.Tab. } 14.1\end{array}$ \\
\hline Grivac & Bln-871 & $\begin{array}{l}\text { Unidentified charcoal from Trench A, } \\
\text { level } 7 \text { associated with Vinča C pottery }\end{array}$ & $6190 \pm 100$ & & & & $\begin{array}{l}\text { McPherron, Srejović } \\
\text { 1988.Tab. 14.1 }\end{array}$ \\
\hline Grivac & Bln-870 & $\begin{array}{l}\text { Unidentified charcoal from a large pit in } \\
\text { subsoil, SE corner of Trench B associ- } \\
\text { ated with Vinča A pottery } \\
\text { (Bogdanović 2004.500) }\end{array}$ & $6315 \pm 100$ & & & & $\begin{array}{l}\text { McPherron, Srejović } \\
\text { 1988.Tab. } 14.1\end{array}$ \\
\hline Anzabegovo & LJ-2411 & $\begin{array}{l}\text { Unidentified charcoal from Sq. VIII, } \\
\text { unit } 55 \text { associated with Vinča B pottery }\end{array}$ & $6070 \pm 190$ & & & & $\begin{array}{l}\text { Gimbutas 1976; } \\
\text { Linick } 1977\end{array}$ \\
\hline Anzabegovo & LJ-2329 & $\begin{array}{l}\text { Unidentified charcoal from Sq. XX, } \\
\text { depth } 190 \mathrm{~cm} \text { below datum associated } \\
\text { with Vinča B pottery }\end{array}$ & $6230 \pm 60$ & & & & $\begin{array}{l}\text { Gimbutas 1976; } \\
\text { Linick } 1977\end{array}$ \\
\hline Pločnik & OxA-14685 & $\begin{array}{l}\text { PL23, Bos sp. proximal tibia from burnt } \\
\text { building debris: Trench 16; spit } 7 \text {; } \\
297.79 m a s l \text {; copper chisel found under } \\
\text { the debris (07/11/2000) associated with } \\
\text { 'Gradac' phase pottery, equivalent here } \\
\text { to Vinča C/D. }\end{array}$ & $5765 \pm 35$ & -20.6 & 5.7 & & Borić 2009 \\
\hline Pločnik & OxA-14686 & $\begin{array}{l}\text { PL24, Bos sp. calcaneus from building } \\
\text { floor: Trench 14; spit 10, 297.29masl; } \\
\text { amorphous lumps of copper (2000) } \\
\text { associated with Vinča B pottery }\end{array}$ & $6046 \pm 37$ & -19.8 & 4.8 & & Borić 2009 \\
\hline Pločnik & OxA-14687 & $\begin{array}{l}\text { PL25, Bos sp. rib from burnt surface: } \\
\text { Trench 14; spit 13, 297.02masl; charcoal, } \\
\text { ash and burnt soil (2000) associated } \\
\text { with Vinča B pottery }\end{array}$ & $6148 \pm 37$ & -21.4 & 6.4 & & Borić 2009 \\
\hline Pločnik & OxA-14688 & $\begin{array}{l}\text { PL26, Bos sp. vertebra from bottom of } \\
\text { trench: Trench 14; spit 22, 295.87masl } \\
\text { (2000) associated with Vinča B pottery }\end{array}$ & $6153 \pm 37$ & -21.0 & 6.8 & & Borić 2009 \\
\hline Pločnik & OxA-14689 & $\begin{array}{l}\text { PL28, Bos-size bone from Surface V: } \\
\text { Trench 15; spit 12; } 300.18 \text { masl; lumps of } \\
\text { thermally changed malachite } \\
(02 / 10 / 2001) \text { associated with } \\
\text { Vinča B pottery }\end{array}$ & $6026 \pm 38$ & -20.4 & 5.8 & & Borić 2009 \\
\hline Pločnik & OxA-14690 & $\begin{array}{l}\text { PL29, dog distal humerus from Oven, } \\
\text { Surface VII: Trench 15; spit 16, } \\
299.56 \text { masl (10/10/2001) associated } \\
\text { with Vinča B pottery }\end{array}$ & $6160 \pm 37$ & -19.2 & 8.5 & & Borić 2009 \\
\hline
\end{tabular}




\begin{tabular}{|c|c|c|c|c|c|c|c|}
\hline Site & $\begin{array}{l}\text { Laboratory } \\
\text { number }\end{array}$ & Material and stratigraphic details & $\begin{array}{c}\text { Radiocarbon } \\
\text { age (BP) }\end{array}$ & $\begin{array}{l}\delta^{13} C \\
(\% \circ)\end{array}$ & $\begin{array}{l}\delta^{15} \mathrm{~N} \\
(\% \circ)\end{array}$ & $\mathrm{C}: \mathrm{N}$ & References \\
\hline Pločnik & OxA-14691 & $\begin{array}{l}\text { PL30, awl from large mammal long } \\
\text { bone from burnt surface: Trench } 15 ; \\
\text { spit 20, 299.ogmasl, charcoal and ash } \\
(11 / 10 / 2001) \text { associated with } \\
\text { Vinča B pottery }\end{array}$ & $6193 \pm 37$ & -20.1 & 5.9 & & Borić 2009 \\
\hline Pločnik & OxA-14692 & $\begin{array}{l}\text { PL31, Bos sp. rib from a hearth: Trench } \\
15 ; \text { spit } 26,298.08 \text { masl; hearth dug into } \\
\text { the sterile soil }(15 / 11 / 2001) \text { associated } \\
\text { with Vinča B pottery }\end{array}$ & $6181 \pm 34$ & -20.6 & 7.6 & & Borić 2009 \\
\hline Oreškovica & OxA-31571 & $\begin{array}{l}\text { Red deer antler tool }\left(S_{1}\right) \text { from the } \\
\text { primary fill (42) of ditch } 47 \text { (trench 1) } \\
\text { associated with Vinča B pottery }\end{array}$ & $6265 \pm 38$ & -21.9 & & & Borić et al. in prep. \\
\hline Oreškovica & OxA-31572 & $\begin{array}{l}\text { Roe deer metatarsus }\left(\mathrm{S}_{4}\right) \text { from the } \\
\text { upper fill (17) of ditch } 47 \text { (trench 1) } \\
\text { associated with Vinča B pottery }\end{array}$ & $6137 \pm 35$ & -21.5 & & & Borić et al. in prep. \\
\hline Oreškovica & OxA-31573 & $\begin{array}{l}\text { Articulated cattle distal metararsus + } \\
\text { phalanx I (S6) from the primary fill (36) } \\
\text { of palisade } 32 \text { (trench 1) associated } \\
\text { with Vinča B pottery }\end{array}$ & $6123 \pm 37$ & -20.3 & & & Borić et al. in prep. \\
\hline Oreškovica & OxA-31574 & $\begin{array}{l}\text { Sus domesticus mandible (S8) from fill } \\
\text { (62) of pit } 18 \text { (trench 2) associated } \\
\text { with Vinča B pottery }\end{array}$ & $6224 \pm 37$ & -20.0 & & & Borić et al. in prep. \\
\hline Oreškovica & OxA-31575 & $\begin{array}{l}\text { Cattle horn core (S9) from fill (14) } \\
\text { (trench 2) associated with } \\
\text { Vinča B pottery }\end{array}$ & $6164 \pm 39$ & -20.7 & & & Borić et al. in prep. \\
\hline Oreškovica & OxA-31576 & $\begin{array}{l}\text { Lepus europeus articulated ulna and } \\
\text { radius (S10) from pit (61) (trench 3) } \\
\text { associated with Vinča B pottery }\end{array}$ & $6206 \pm 37$ & -17.9 & & & Borić et al. in prep. \\
\hline Selevac & HAR 3211 & $\begin{array}{l}\text { Unidentified charcoal from Trench 18, } \\
\text { quad. 2, level } 9 \text { (BH 77-78: V) associ- } \\
\text { ated with Vinča B2 pottery }\end{array}$ & $6050 \pm 70$ & -26.0 & & & $\begin{array}{l}\text { Tringham, Krstić } \\
1990 \mathrm{C}\end{array}$ \\
\hline Selevac & HAR 3217 & $\begin{array}{l}\text { Unidentified wood from Feature } 227 \text { in } \\
\text { Trench } 14 \text { (BH 77-78: VII, VIII or IX) } \\
\text { associated with Vinča B2/C pottery }\end{array}$ & $6240 \pm 100$ & -26.3 & & & $\begin{array}{l}\text { Tringham, Krstić } \\
1990 \mathrm{C}\end{array}$ \\
\hline$\overline{\text { Selevac }}$ & HAR 3218 & $\begin{array}{l}\text { Unidentified charcoal from Trench 18, } \\
\text { quad. 3/4, level } 10 \text { (BH 77-78: IX?) } \\
\text { associated with Vinča C pottery }\end{array}$ & $5670 \pm 80$ & $-25 \cdot 3$ & & & $\begin{array}{l}\text { Tringham, Krstić } \\
1990 \mathrm{C}\end{array}$ \\
\hline$\overline{\text { Selevac }}$ & HAR 3220 & $\begin{array}{l}\text { Unidentified charcoal from Feature } 44 \\
\text { collapsed oven superstructure }(\mathrm{BH} 77- \\
78: \mathrm{VI}) \text { associated with Vinča } \mathrm{B} 2 \text { pottery }\end{array}$ & $6100 \pm 70$ & -27.1 & & & $\begin{array}{l}\text { Tringham, Krstić } \\
1990 \mathrm{C}\end{array}$ \\
\hline Selevac & HAR 3221 & $\begin{array}{l}\text { Unidentified charcoal from Feature 210, } \\
\text { ditch related to House } 4 \text { ( } \mathrm{BH} \text { 77-78: VII) } \\
\text { associated with Vinča B2/C pottery }\end{array}$ & $6050 \pm 70$ & -26.7 & & & $\begin{array}{l}\text { Tringham, Krstić } \\
1990 \mathrm{C}\end{array}$ \\
\hline Selevac & HAR 3222 & $\begin{array}{l}\text { Grain (whole) from Feature } 60 \\
\text { (House 7) (BH 77-78: II) associated } \\
\text { with Vinča B1 pottery }\end{array}$ & $6230 \pm 100$ & -25.6 & & & $\begin{array}{l}\text { Tringham, Krstić } \\
1990 \mathrm{C}\end{array}$ \\
\hline$\overline{\text { Selevac }}$ & HAR 3230 & $\begin{array}{l}\text { Unidentified charcoal from Feature } 220 \text {, } \\
\text { deep posthole }(\mathrm{BH} 77-78 \text { : VIII or IX) } \\
\text { associated with Vinča } \mathrm{B} 2 / \mathrm{C} \text { pottery }\end{array}$ & $5750 \pm 80$ & -25.7 & & & $\begin{array}{l}\text { Tringham, Krstić } \\
1990 \mathrm{C}\end{array}$ \\
\hline$\overline{\text { Selevac }}$ & HAR 3232 & $\begin{array}{l}\text { Unidentified charcoal lens from } \\
\text { Feature } 62(\mathrm{BH} 77-78: \mathrm{V}) \text { associated } \\
\text { with Vinča } \mathrm{B} 2 \text { pottery }\end{array}$ & $6040 \pm 70$ & $-25 \cdot 5$ & & & $\begin{array}{l}\text { Tringham, Krstić } \\
1990 \mathrm{C}\end{array}$ \\
\hline Selevac & LJ-2521 & $\begin{array}{l}\text { Grain from Silo } A \text { associated with } \\
\text { Vinča B } 1 \text { pottery }\end{array}$ & $6080 \pm 70$ & & & & Linick 1977 \\
\hline Selevac & Z-233a & Wheat grain from Silo $\mathrm{A}$ & $6113 \pm 80$ & & & & Srdoć et al. 1975 \\
\hline Selevac & Z-233b & Wheat grain from Silo $\mathrm{A}$ & $6152 \pm 90$ & & & & Srdoć et al. 1975 \\
\hline Selevac & Z-233 & Wheat grain from Silo $\mathrm{A}$ & $6366 \pm 100$ & & & & Srdoć et al. 1975 \\
\hline
\end{tabular}




\begin{tabular}{|c|c|c|c|c|c|c|c|}
\hline Site & $\begin{array}{l}\text { Laboratory } \\
\text { number }\end{array}$ & Material and stratigraphic details & $\begin{array}{l}\text { Radiocarbon } \\
\text { age (BP) }\end{array}$ & $\begin{array}{l}\delta^{13 C} \\
(\% \circ)\end{array}$ & $\begin{array}{l}\delta^{15 N} \\
(\% \circ)\end{array}$ & $\mathrm{C}: \mathrm{N}$ & References \\
\hline Predionica & Bln-435 & $\begin{array}{l}\text { Charcoal, Quercus sp. from fire } \\
\text { installation in Level } 3 b \text { at } 1.8 \mathrm{~m} \\
\text { associated with Vinča A pottery } \\
\text { (Quitta, Kohl 1969.237) }\end{array}$ & $6280 \pm 80$ & & & & Quitta, Kohl 1969 \\
\hline Valač & Bln-436 & $\begin{array}{l}\text { Mixed sample of charred acorns and } \\
\text { seeds of sf. Pisum sp. from charred and } \\
\text { ashy infill of a cut feature } 0.7 m \text { from } \\
\text { the surface in sondage P-3 associated } \\
\text { with Vinča D pottery } \\
\text { (Quitta, Kohl 1969.237) }\end{array}$ & $5895 \pm 80$ & & & & $\begin{array}{l}\text { Quitta, Kohl 1969; } \\
\text { Gimbutas } 1974\end{array}$ \\
\hline Beran-Krš & Z-491 & $\begin{array}{l}\text { Unidentified charcoal from context with } \\
\text { variable information: Trench III, level } 7 \\
\text { (Srdoć et al. 1977) or level } 3 \text { or } 4 \text { from } \\
\text { building horizon Ila associated with } \\
\text { Vinča C pottery (Marković 1985) }\end{array}$ & $6030 \pm 60$ & & & & $\begin{array}{l}\text { Srdoć et al. 1977.474; } \\
\text { Marković } 1985.70\end{array}$ \\
\hline Beran-Krš & Z-492 & $\begin{array}{l}\text { Unidentified charcoal from context } \\
\text { with variable information Trench III, } \\
\text { level } 13 \text { (base of excavation) } \\
\text { (Srdoć et al. 1977) or level } 3 \text { or } 4 \text { from } \\
\text { building horizon Ila associated with } \\
\text { Vinča C pottery (Marković 1985) }\end{array}$ & $5870 \pm 150$ & & & & $\begin{array}{l}\text { Srdoć et al. 1977.474; } \\
\text { Marković } 1985.70\end{array}$ \\
\hline $\begin{array}{l}\text { Donje } \\
\text { Vranje }\end{array}$ & $\begin{array}{c}\text { SUERC- } \\
57927\end{array}$ & Bos or Cervus bone from Pit in KRS1 & $6206 \pm 33$ & -21.1 & & & Kapuran et al. 2016 \\
\hline Gornea & BM-1124 & $\begin{array}{l}\text { Charcoal (ref 1974/57); charcoal frag- } \\
\text { ments from Trench 23, sq. 1, Pit 21, } \\
\text { spits 4-6 associated with Vinča A } \\
\text { pottery (Burleigh, Hewson 1979.350) }\end{array}$ & $5871 \pm 54$ & -25.8 & & & $\begin{array}{l}\text { Burleigh, Hewson } \\
1979\end{array}$ \\
\hline Liubcova & $B \ln -2133$ & \begin{tabular}{|l|}
$\begin{array}{l}\text { Charred grain associated with Vinča B2 } \\
\text { pottery (László 1997.260) }\end{array}$
\end{tabular} & $6175 \pm 85$ & & & & László 1997 \\
\hline
\end{tabular}

